\title{
Responses of Southern Ocean Seafloor Habitats and Communities to Global and Local Drivers of Change
}

Madeleine J. Brasier ${ }^{1 *}$, David Barnes², Narissa Bax ${ }^{3}$, Angelika Brandt $^{4,5}$, Anne B. Christianson ${ }^{6,7}$, Andrew J. Constable ${ }^{3,8}$, Rachel Downey ${ }^{9}$, Blanca Figuerola ${ }^{10}$, Huw Griffiths ${ }^{2}$, Julian Gutt ${ }^{11}$, Susanne Lockhart ${ }^{12}$, Simon A. Morley ${ }^{2}$, Alexandra L. Post ${ }^{13}$, Anton Van de Putte ${ }^{14,15,16 t}$, Hanieh Saeedi ${ }^{4,5,17}$, Jonathan S. Stark ${ }^{8}$, Michael Sumner ${ }^{8}$ and Catherine L. Waller ${ }^{18}$

\section{OPEN ACCESS}

Edited by:

Paul E. Renaud,

Akvaplan-niva, Norway

Reviewed by:

Amanda Fern Ziegler,

UiT The Arctic University of Norway,

Norway

Hunter Lenihan

University of California,

Santa Barbara, United States

*Correspondence:

Madeleine J. Brasier

madeleine.brasier@utas.edu.au

tORCID:

Anton Van de Putte orcid.org/0000-0003-1336-5554

Specialty section:

This article was submitted to Global Change and the Future Ocean,

a section of the journal

Frontiers in Marine Science

Received: 29 October 2020

Accepted: 27 January 2021

Published: 13 May 2021

Citation:

Brasier MJ, Barnes D, Bax N,

Brandt A, Christianson AB,

Constable AJ, Downey R,

Figuerola B, Griffiths H, Gutt J,

Lockhart S, Morley SA, Post AL, Van de Putte A, Saeedi H, Stark JS,

Sumner M and Waller CL (2021)

Responses of Southern Ocean Seafloor Habitats and Communities to Global and Local Drivers of Change.

Front. Mar. Sci. 8:622721.

doi: 10.3389/fmars.2021.622721
${ }^{1}$ Institute for Marine and Antarctic Studies, University of Tasmania, Hobart, TAS, Australia, ${ }^{2}$ British Antarctic Survey, Cambridge, United Kingdom, ${ }^{3}$ Centre for Marine Socioecology, Institute for Marine and Antarctic Studies, University of Tasmania, Hobart, TAS, Australia, ${ }^{4}$ Senckenberg Research Institute and Natural History Museum, Frankfurt, Germany, ${ }^{5}$ Institute for Ecology, Evolution and Diversity, Goethe University Frankfurt, Frankfurt, Germany, ${ }^{6}$ The Pew Charitable Trusts, Washington, DC, United States, ' Department of Forest Resources, University of Minnesota Twin Cities, Minneapolis, MN, United States, ${ }^{8}$ Australian Antarctic Division, Kingston, TAS, Australia, ${ }^{9}$ Fenner School of Environment and Society, Australian National University, Canberra, ACT, Australia, ${ }^{10}$ Institute of Marine Sciences (ICM-CSIC), Barcelona, Spain, ${ }^{11}$ Alfred Wegener Institute, Helmholtz Centre for Polar and Marine Research, Bremerhaven, Germany, ${ }^{12}$ California Academy of Sciences, San Francisco, CA, United States, ${ }^{13}$ Geoscience Australia, Canberra, ACT, Australia, ${ }^{14}$ Royal Belgian Institute of Natural Sciences, OD-Nature, Brussels, Belgium, ${ }^{15}$ Laboratory of Biodiversity and Evolutionary Genomics, KU Leuven, Leuven, Belgium, ${ }^{16}$ Marine Biology Lab, Université libre de Bruxelles, Brussels, Belgium, ${ }^{17}$ OBIS Data Manager, Deep-Sea Node, Frankfurt, Germany, ${ }^{18}$ Faculty of Science and Engineering, University of Hull, Hull, United Kingdom

Knowledge of life on the Southern Ocean seafloor has substantially grown since the beginning of this century with increasing ship-based surveys and regular monitoring sites, new technologies and greatly enhanced data sharing. However, seafloor habitats and their communities exhibit high spatial variability and heterogeneity that challenges the way in which we assess the state of the Southern Ocean benthos on larger scales. The Antarctic shelf is rich in diversity compared with deeper water areas, important for storing carbon ("blue carbon") and provides habitat for commercial fish species. In this paper, we focus on the seafloor habitats of the Antarctic shelf, which are vulnerable to drivers of change including increasing ocean temperatures, iceberg scour, sea ice melt, ocean acidification, fishing pressures, pollution and non-indigenous species. Some of the most vulnerable areas include the West Antarctic Peninsula, which is experiencing rapid regional warming and increased iceberg-scouring, subantarctic islands and tourist destinations where human activities and environmental conditions increase the potential for the establishment of non-indigenous species and active fishing areas around South Georgia, Heard and MacDonald Islands. Vulnerable species include those in areas of regional warming with low thermal tolerance, calcifying species susceptible to increasing ocean acidity as well as slow-growing habitat-forming species that can be damaged by fishing gears e.g., sponges, bryozoan, and coral species. Management regimes can protect seafloor habitats and key species from fishing activities; some areas will need more protection than others, accounting for specific traits that make species vulnerable, slow growing and long-lived species, restricted locations with optimum physiological 
conditions and available food, and restricted distributions of rare species. Ecosystembased management practices and long-term, highly protected areas may be the most effective tools in the preservation of vulnerable seafloor habitats. Here, we focus on outlining seafloor responses to drivers of change observed to date and projections for the future. We discuss the need for action to preserve seafloor habitats under climate change, fishing pressures and other anthropogenic impacts.

Keywords: benthos, Antarctica, Southern Ocean, marine protected areas, vulnerable marine ecosystems, fishing

\section{INTRODUCTION}

The benthic habitats of the Southern Ocean are hugely variable, from ice scoured shallows to rich, dense shelf communities with many endemic species and mosaics of areas variously dominated by suspension or deposit feeders and their predators. These habitats are a store of exported carbon from the overlying pelagic productivity and habitat for commercial fish species. This paper is a contribution to the Marine Ecosystem Assessment for the Southern Ocean (hereafter termed MEASO). In this benthic assessment, we identify the pathways of impact by global drivers (Morley et al., 2020) and local drivers (Grant et al., in review, to be published in this research topic) (Figure 1) and discuss the observed and projected implications of those impacts on benthic communities across the Southern Ocean. Specifically, we discuss the direct and indirect impacts of increasing ocean temperature, ocean acidification, and marine ice losses (ice shelves, glaciers, and sea ice), the latter which will result in increased ice scour, light, and sedimentation, changing primary production and biogenic flux. We also consider the impacts of fishing, plastics, chemical pollution and non-indigenous species. Whilst we cannot discuss all drivers and recorded observations of change in detail, we aim to highlight the key impacts that likely influence benthic biodiversity and production.

\section{Physical Setting}

The shallowest habitat of the Southern Ocean is the intertidal zone at the very edge of the continent of Antarctica and subantarctic islands. Habitats shallower than $100 \mathrm{~m}$ are relatively rare and estimated to have a total area of approximately $25,000 \mathrm{~km}^{2}$ (Clark et al., 2015). The intertidal extends into the continental shelf, which is unusually deep in a global context, averaging $450 \mathrm{~m}$ but exceeding $1000 \mathrm{~m}$ in some places, including inner shelf canyons and valleys (Harris and O'Brien, 1996; Beaman and Harris, 2005). The depth of the continental shelf is due to isostatic depression under the weight of glacial ice, and glacial erosion over geological time of the Antarctic continental shelf (Clarke and Johnston, 2003). The continental shelf covers an area of $\sim 4.1$ million $\mathrm{km}^{2}$; the continental shelf can reach up to $1000 \mathrm{~km}$ from continental margin to shelf edge, and the widest areas have large floating ice shelves (Post et al., 2014). Benthic communities of the continental shelf can underlie ice shelves and fast ice or may be ice-free with seasonally shifting ice regimes. The continental shelf joins the continental slope at the shelf break. The slope is steep, overlain by circumpolar deep water $\left(2-2.5^{\circ} \mathrm{C}\right.$ ), and its gradient (generally $5-15^{\circ}$, with some areas up to $26^{\circ}$ ) declines toward the abyssal plain at $\sim 3000 \mathrm{~m}$ depth (Kaiser et al., 2011; Arndt et al., 2013; Figure 2). Seafloor areas that are shallower than $1000 \mathrm{~m}$ can occur in the Southern Ocean around subantarctic islands and on banks, plateau, and seamounts. For simplicity and unless otherwise specifically stated, we use the term "shelf areas" to collectively encompass these shallow areas and the Antarctic continental shelf.

Seafloor environments are influenced by different sedimentary and oceanographic processes, which in addition to depth define the habitat (Post et al., 2014). Physical seafloor features, referred to as geomorphic features, incorporate the shape of the seafloor (e.g., ridges, troughs, basins, canyons, etc.) and substratum type (e.g., hard, poorly sorted, or soft). Mapping the geomorphology of the seafloor provides a broad-scale indication of benthic habitats and associated biological communities (e.g., Beaman and Harris, 2005; Gutt et al., 2007; Post et al., 2010, 2017). Figure 3 highlights the geomorphic features of the Southern Ocean across MEASO areas. In this assessment, we focus on the "shelf areas."

Shelf areas are not smooth areas extending from the shelf break to the intertidal (or shallowest point on a bank/seamount), instead they are broken up by deep troughs (deeps) eroded by glacial expansion during past glaciations, which form modern depocenters for sedimentation (shelf deeps). These deeps are typically associated with mobile scavengers and infauna living in the seafloor sediments. Where shelf deeps connect to the continental slope, they form cross-shelf valleys and canyons, providing a pathway for ocean circulation and food transfer between shelf and slope environments. Relatively shallow shelf banks, formed due to bypass of the mobile ice sheet around these broad features, are typically scoured by icebergs. Shelf banks usually contain communities in various stages of recolonization, from pioneer species through to later successional stages (e.g., Gutt and Starmans, 2001). Coastal terrane occurs at depths shallower than $200 \mathrm{~m}$, within the photic zone unless covered by ice. Features in these areas are often rugged and rocky, consisting of deep basins, steep gullies and channels eroded by small coastal glaciers (e.g., Beaman and Harris, 2003). In nearshore areas experiencing sea ice for approximately 11 months or more annually, sessile invertebrates tend to dominate rocky and rugged seafloor habitats rather than macroalgae (Clark et al., 2013).

\section{State of Knowledge of the Southern Ocean Benthos}

Until relatively recently benthic research focused on areas within $150 \mathrm{~km}$ of research stations (Griffiths, 2010), however there is an increasing effort to sample slope communities and the deep 


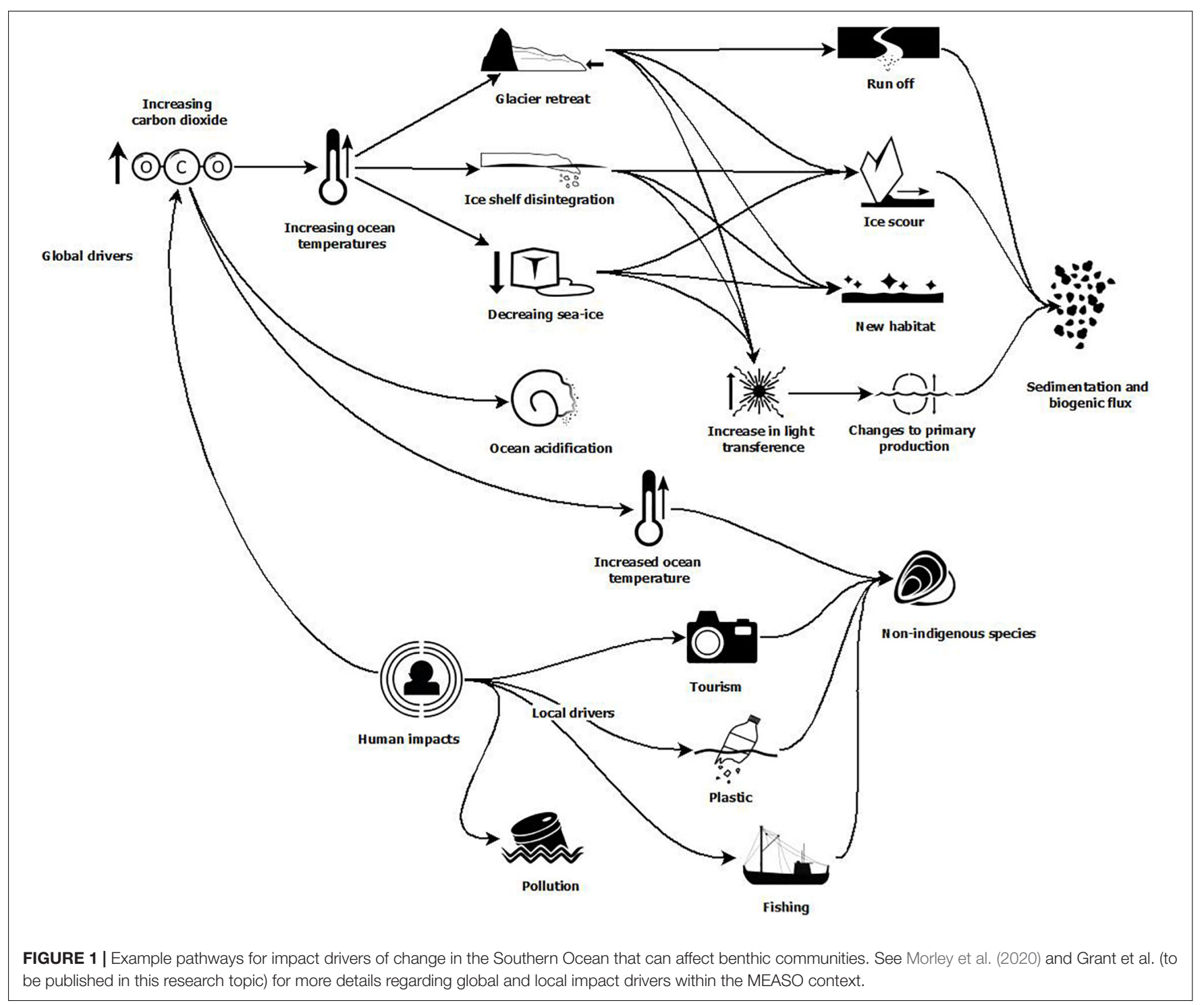

sea (e.g., Brandt et al., 2007; Kaiser et al., 2013). Observations and models that support projects like MEASO are described in Brasier et al. (2019) which includes the first Western scientific and discovery expeditions to reach Antarctica in the 1750s. Some of the earliest working research bases were established in midtwentieth century for both scientific endeavors and territorial claims (Walton and Bonner, 1985). Table 1 indicates the evolution of benthic research via large scale research programmes since the 1961 adoption of the Antarctic Treaty. In this paper we present observation findings and acknowledge the differences in temporal and spatial coverage across MEASO areas.

Using the Ocean Biogeographic Information System (OBIS) and Global Biodiversity Information Facility (GBIF) databases, we categorized, where possible, species distributed in the MEASO area to benthic, pelagic, and unknown (see Supplementary Information for more details). All the extracted data were cleaned and went through a careful quality control process (see Supplementary Information). The spatial coverage of 161,711 distribution records (hereafter termed the benthic records) displayed in Figure 4 show the highest concentration of records within the Antarctic zone are in the Ross Sea (West Pacific), West Antarctic Peninsula region (East Pacific and Atlantic), and Weddell Sea (Atlantic). In the subantarctic zone benthic records concentrate in the Scotia Arc (Atlantic), Kerguelen region (Central Indian), the northern zone off New Zealand and Macquarie (West Pacific and East Indian). This is a reflection of sampling and research effort in these areas that is noted in earlier studies (Griffiths, 2010; Grant et al., 2011).

The benthic records represent 7,945 benthic species, although these results are likely an under-representation of benthic biodiversity in the Southern Ocean. The total expected number of macrozoobenthic species for the entire Southern Ocean shelf area lies between 11,000 and 17,000 species (Gutt et al., 2004). However, Gutt et al.'s (2004) estimate is conservative for Southern Ocean benthos overall, as we continue to find new species with more benthic sampling, especially in deep-sea habitats 


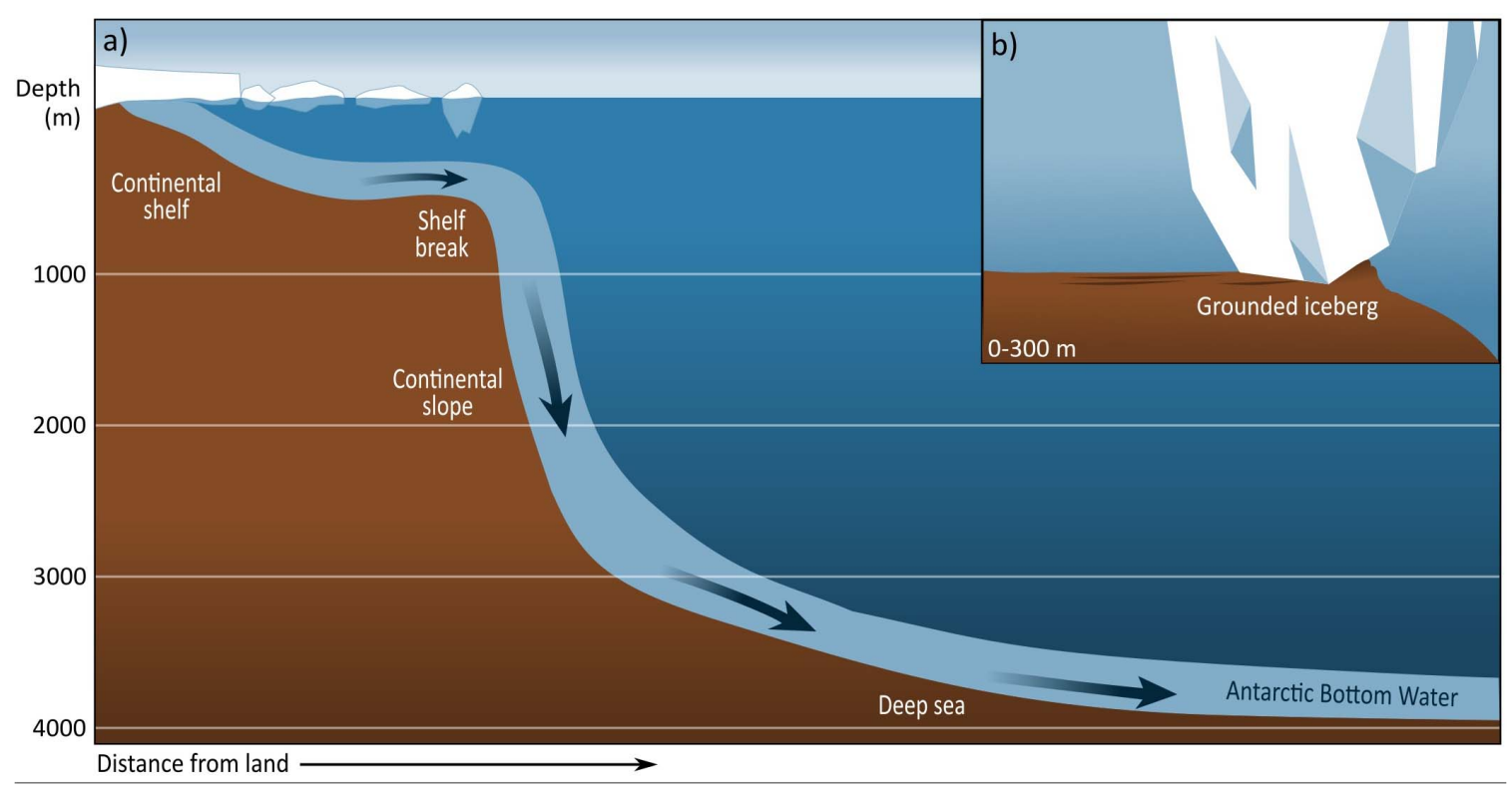

FIGURE 2 | (a) Depth profile of Southern Ocean seafloor and (b) grounded iceberg on the Antarctic shelf, grounding like this is most common between 0 and $300 \mathrm{~m}$.

(Brandt et al., 2007, 2012; Kaiser et al., 2013). It also does not incorporate the potential for cryptic species, i.e., those that are morphologically identical but genetically distinct, which is considered a common feature of the Southern Ocean fauna (e.g., polychaetes - Schüller, 2011; Neal et al., 2014; Brasier et al., 2016; crustaceans - Held, 2003; Raupach et al., 2007; Baird et al., 2011; Havermans et al., 2011; molluscs - Linse et al., 2007; Allcock et al., 2011; echinoderms - Wilson et al., 2009; Janosik and Halanych, 2010, pycnogonids - Krabbe et al., 2010; nematodes - Thornhill et al., 2008; sponges - Vargas et al., 2017).

With an increasing amount of data for Southern Ocean benthic species, there is continuing effort to increase biological information available within species databases. For example, the Register of Antarctic Marine Species (RAMS), which was established as a standard reference for marine biodiversity research, conservation and sustainable management, contains an authoritative taxonomic list of species occurring within the Southern Ocean. Work is now underway to add additional "trait" data to RAMS, including categorical and quantitative information about species life history, habitat, diet and physiology. These data can be used for functional analyses, to help identify sensitive species or functional groups and can be combined with spatial data and climate projections to identify where and when these groups might be affected by external drivers.

\section{Biological Traits of Southern Ocean Benthic Species}

The modern Southern Ocean benthos has evolved both in situ and via exchange with surrounding deep basins of the Indian, Pacific, and Atlantic Oceans. In situ evolution and relative isolation of some benthic habitats may have driven the relatively high degree of endemism - ranging from 60 to $90 \%$ of species (Arntz et al., 1997; Brandt and Gutt, 2011). The isothermal water column has also facilitated down-slope (submergence) and up-slope migrations (emergence) of refugial populations during glacial cycles, resulting in an abundance of eurybathic species, or species able to live over a wide depth range (Brey et al., 1996; Brandt et al., 2005). Colonization of the Antarctic shelf from either deep-sea regions around Antarctica, via the Scotia Arc or caused by the breakup of Gondwana during the Cenozoic Era, has only been investigated in some taxa such as isopods, corals, echinoderms, bivalves, and bryozoans (e.g., Brandt, 1991, 1999; Brandt et al., 1999; Figuerola et al., 2014, 2017).

The Southern Ocean benthos has thrived under comparatively constant, cool conditions for millions of years. Ocean temperatures range from -1.9 at their coldest to $5^{\circ} \mathrm{C}$ at the northern limit of the Southern Ocean, leading to the evolution of many physiological adaptations that protect benthic organisms against, or overcome the extreme effects of, cold conditions. Examples include the presence of antifreeze in the tissues of many Southern Ocean fish that reduces their freezing point to below that of seawater $\left(-4^{\circ} \mathrm{C}\right)$ (DeVries, 1971), and polar gigantism, where the low metabolic rates at low temperatures and the slightly increased oxygen concentration in cold water which may have resulted in some marine invertebrates becoming bigger than ecologically equivalent species from warmer environments (Chapelle and Peck, 1999). At the community level, along the continental shelf and nearshore regions, the rarity of skeleton-crushing (durophagous) predators such as bony fish, sharks, brachyuran crabs and lobsters is a key feature of the Southern Ocean benthos (Aronson et al., 2007). For some species their rarity is due to physiological implications of living in cold temperatures. For example, brachyuran crabs are unable to regulate magnesium levels in their blood at temperatures 


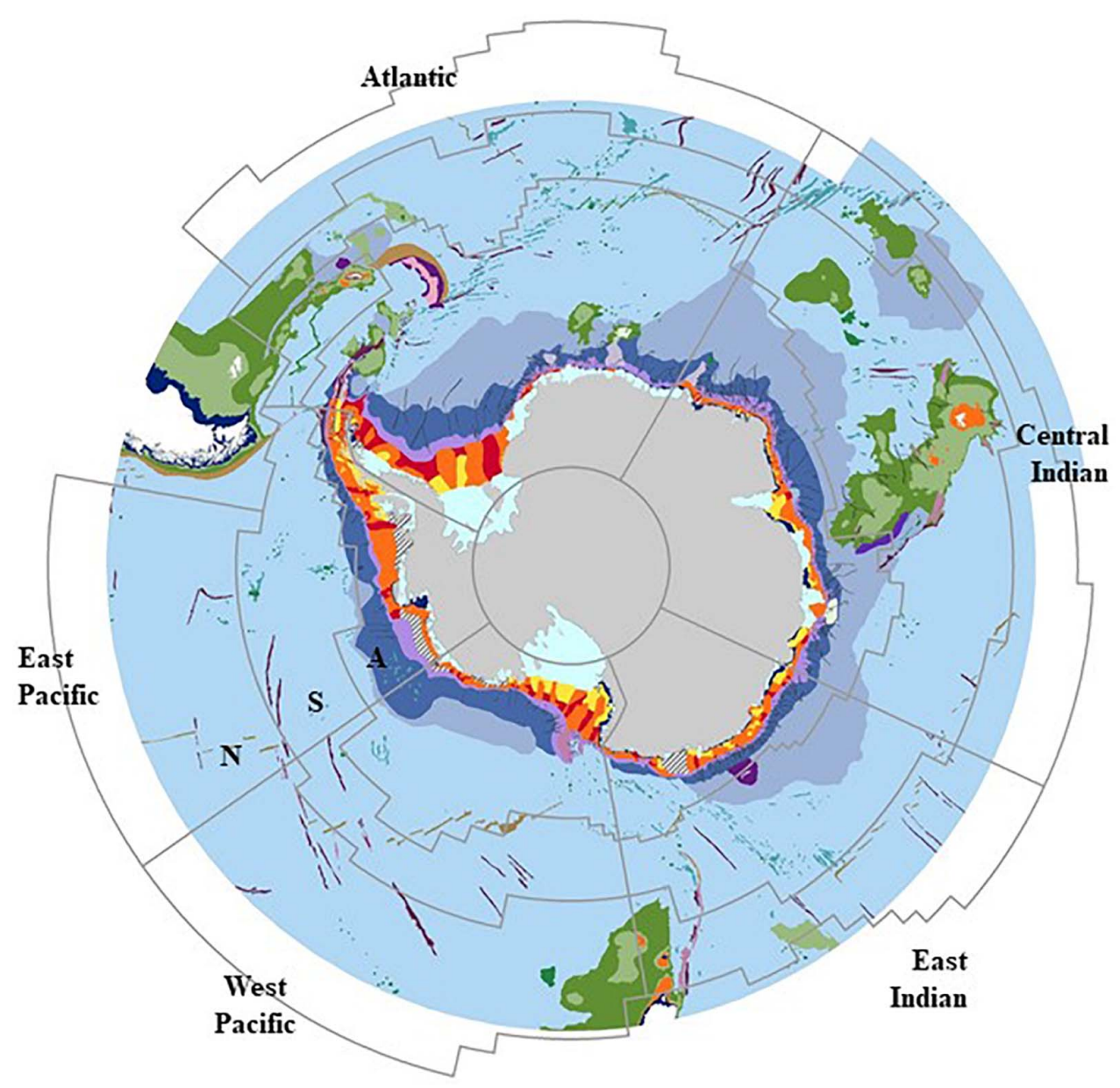

\begin{tabular}{|c|c|c|c|}
\hline \multicolumn{4}{|l|}{ Geomorphic features } \\
\hline Bank & Canyon & Contourite Feature & Island Arc \\
\hline Shelf Deep & Trough Mouth Fan & Seamount & Volcano \\
\hline Cross Shelf Valley & Structural Slope & Seamount Ridges & Plateau \\
\hline Coastal/Shelf Terrane & Margin Ridges & Abyssal Plain - rough & Plateau Slope \\
\hline Coastal ice feature & Marginal Plateau & Abyssal Plain - smooth & Ridge \\
\hline Upper Slope & Mid Ocean Ridge Valley & Trough & No data \\
\hline Lower Slope & Fracture Zone Scarp & Trench & \\
\hline
\end{tabular}

FIGURE 3 | Geomorphic features of the Southern Ocean. MEASO areas are shown (thin gray lines) including MEASO sectors (Atlantic, Central Indian, East Indian, West Pacific, East Pacific) and MEASO zones (where N = northern, S = subantarctic, A = Antarctic). Data adapted from O'Brien et al. (2009); Post et al. (2014), definitions of geomorphic features are provided in Supplementary Information.

$<0^{\circ} \mathrm{C}$, reducing the scope of aerobic activity (Frederich et al., 2001), thereby limiting their ranges.

\section{Benthic Communities of the Southern Ocean}

Benthic communities are influenced by multiple environmental factors that vary across spatial scales (e.g., Gutt et al., 2019). These can include but are not limited to depth, substrate type, food availability, temperature, salinity, oxygen availability, sea ice cover and disturbance. Generalized patterns within benthic communities are described here whilst recognizing they are subject to local and regional variation. Benthos on the Antarctic continental shelf is made up of two core communities, one is dominated by sessile suspension feeders such as sponges, bryozoans, cnidarians and ascidians, which are supported by food in strong near-bottom currents and thrive on "hard substrates" including coarse-grained sediment, gravel, rocks or dropstones 
TABLE 1 | Examples of benthic species, community and ecosystem level observations within large scale research programmes including the timescale of observations and areas of study.

\begin{tabular}{|c|c|c|c|c|c|c|c|}
\hline Topic & Study & Timescale & $\begin{array}{l}\text { Spatial } \\
\text { scale }\end{array}$ & Locations & MEASO area* & Depth** & Programmes ${ }^{\star \star \star}$ \\
\hline Single species & $\begin{array}{l}\text { Reproductive } \\
\text { monitoring }\end{array}$ & 1990s onward & Local & Antarctic Peninsula & EP-A & Shallow & AnT-ERA \\
\hline Single species & Ecophysiology & 2000s onward & Local & $\begin{array}{l}\text { Antarctic Peninsula, } \\
\text { Davies Sea }\end{array}$ & EP-A, Cl-A, El-A & Shallow & AnT-ERA \\
\hline Single species & Molecular response & 2000s onward & Local & Antarctic Peninsula & EP-A & Shallow & AnT-ERA \\
\hline Single species & Thermal tolerance & 1990s onward & Local & Antarctic Peninsula & EP-A & $\begin{array}{l}\text { Shallow and } \\
\text { shelf }\end{array}$ & AnT-ERA \\
\hline Single species & $\begin{array}{l}\text { Acidification } \\
\text { experiments }\end{array}$ & 2000s onward & Local & $\begin{array}{l}\text { Antarctic Peninsula, } \\
\text { Davies Sea }\end{array}$ & EP-A & Shallow & AnT-ERA \\
\hline Single species & Ecotoxicology & 2000s onward & Local & Antarctic Peninsula & EP-A Cl-A, El-A & Shallow & \\
\hline $\begin{array}{l}\text { Single species \& } \\
\text { community }\end{array}$ & $\begin{array}{l}\text { Genetics and } \\
\text { phylogeography }\end{array}$ & 2000s onward & $\begin{array}{l}\text { Local to } \\
\text { circumpolar }\end{array}$ & $\begin{array}{l}\text { Antarctic Peninsula, } \\
\text { Amundsen Sea, } \\
\text { Weddell Sea, Ross } \\
\text { Sea Dumont } \\
\text { D'Urville Sea, } \\
\text { Davies Sea, Prydz } \\
\text { Bay, subantarctic } \\
\text { islands }\end{array}$ & EP-A, El-A, Cl-A & $\begin{array}{l}\text { Shallow to } \\
\text { deep-sea }\end{array}$ & CAML, AntECO \\
\hline $\begin{array}{l}\text { Single species \& } \\
\text { community }\end{array}$ & $\begin{array}{l}\text { Non-indigenous } \\
\text { species (benthic } \\
\text { marine) }\end{array}$ & 2000s onward & Local & $\begin{array}{l}\text { Antarctic Peninsula } \\
\text { and subantarctic } \\
\text { islands }\end{array}$ & $\begin{array}{l}\text { EP-A, AO-S, El-S, } \\
\text { Cl-A }\end{array}$ & $\begin{array}{l}\text { Shallow and } \\
\text { shelf }\end{array}$ & AntECO, CEP \\
\hline Community & $\begin{array}{l}\text { Diversity and } \\
\text { Community } \\
\text { monitoring }\end{array}$ & 1960 onward & $\begin{array}{l}\text { Local to } \\
\text { regional }\end{array}$ & $\begin{array}{l}\text { Antarctic Peninsula, } \\
\text { Ross Sea, Weddell } \\
\text { Sea, South Georgia }\end{array}$ & $\begin{array}{l}\text { EP-A, AO-A, AO-S, } \\
\text { WP-A }\end{array}$ & $\begin{array}{l}\text { Shallow and } \\
\text { shelf }\end{array}$ & $\begin{array}{l}\text { AntECO, SOOS, } \\
\text { AntOBIS or } \\
\text { biodiversity.aq }\end{array}$ \\
\hline Community & $\begin{array}{l}\text { Changing ice } \\
\text { regimes }\end{array}$ & 1990s onward & $\begin{array}{l}\text { Local to } \\
\text { regional }\end{array}$ & $\begin{array}{l}\text { Antarctic Peninsula, } \\
\text { Weddell Sea }\end{array}$ & EP-A, A-A & $\begin{array}{l}\text { Shallow and } \\
\text { shelf }\end{array}$ & $\begin{array}{l}\text { ICED, SOOS, } \\
\text { AntOBIS or } \\
\text { biodiversity.aq }\end{array}$ \\
\hline Community & Biogeography & $\begin{array}{l}\text { Spatial survey } \\
\text { only }\end{array}$ & $\begin{array}{l}\text { Regional to } \\
\text { circumpolar }\end{array}$ & Circumpolar & All & $\begin{array}{l}\text { Shallow to } \\
\text { deep-sea }\end{array}$ & CAML, AntECO \\
\hline Community & VME encounters & 2009 onward & Local & $\begin{array}{l}\text { Mostly Scotia Arc, } \\
\text { Antarctic Peninsula, } \\
\text { Weddell Sea and } \\
\text { Ross Sea }\end{array}$ & $\begin{array}{l}\text { EP-A, AO-S, AO-A, } \\
\text { WP-A }\end{array}$ & $\begin{array}{l}\text { Shelf to } \\
\text { deep-sea }\end{array}$ & FSA, AntECO \\
\hline Ecosystem & $\begin{array}{l}\text { Carbon } \\
\text { sequestration }\end{array}$ & Since 1980s & $\begin{array}{l}\text { Local to } \\
\text { circumpolar }\end{array}$ & $\begin{array}{l}\text { Antarctic Peninsula, } \\
\text { Amundsen Sea, } \\
\text { Weddell Sea, Ross } \\
\text { Sea }\end{array}$ & EP-A, A-A, WP-A & $\begin{array}{l}\text { Shallow and } \\
\text { shelf }\end{array}$ & $\begin{array}{l}\text { ICED, JGFOS, } \\
\text { GLOBEC }\end{array}$ \\
\hline Ecosystem & Food webs & $\begin{array}{l}\text { no time series } \\
\text { assessment }\end{array}$ & Regional & Weddell Sea & $\mathrm{AO}-\mathrm{A}$ & Shelf & ICED, AnT-ERA \\
\hline Ecosystem & $\begin{array}{l}\text { Bentho-pelagic } \\
\text { coupling }\end{array}$ & $\begin{array}{l}\text { no time series } \\
\text { assessment }\end{array}$ & $\begin{array}{l}\text { Local to } \\
\text { regional }\end{array}$ & $\begin{array}{l}\text { West Antarctic } \\
\text { Peninsula }\end{array}$ & EP-A & Shelf & ICED, AnT-ERA \\
\hline Ecosystem & $\begin{array}{l}\text { Distribution } \\
\text { mapping \& } \\
\text { eco-regionalization }\end{array}$ & $\begin{array}{l}\text { Spatial survey } \\
\text { capable of } \\
\text { future } \\
\text { projections }\end{array}$ & $\begin{array}{l}\text { Local to } \\
\text { circumpolar }\end{array}$ & Circumpolar & All & $\begin{array}{l}\text { Intertidal to } \\
\text { deep-sea }\end{array}$ & AntECO \\
\hline Ecosystem & Ecosystem models & $\begin{array}{l}\text { Spatial survey } \\
\text { capable of } \\
\text { future } \\
\text { projections }\end{array}$ & $\begin{array}{l}\text { Local to } \\
\text { circumpolar }\end{array}$ & $\mathrm{Na}$ & All & Shelf & ICED \\
\hline
\end{tabular}

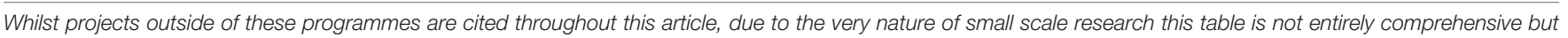

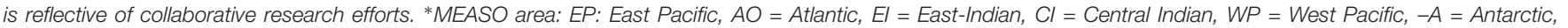

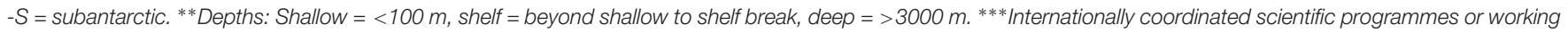

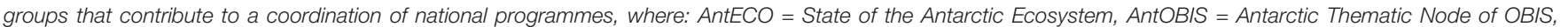

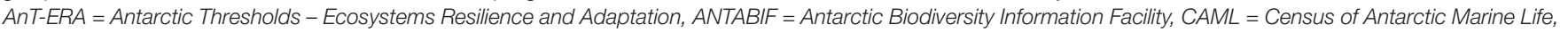

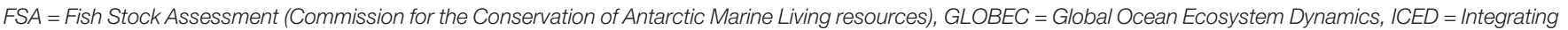
Climate and Ecosystem Dynamics, JGOFS = Joint Global Ocean Flux Study, SOOS = Southern Ocean Observing System.

(Gutt, 2007; Brandt and Gutt, 2011; Figure 5). The second core community, which dominates soft-sediment habitats and includes infauna and mobile epifauna, is controlled by the deposition of phytodetritus, surface derived organic particles from decomposing phytoplankton that become a food resource for benthic species. Similar differences between hard- and 


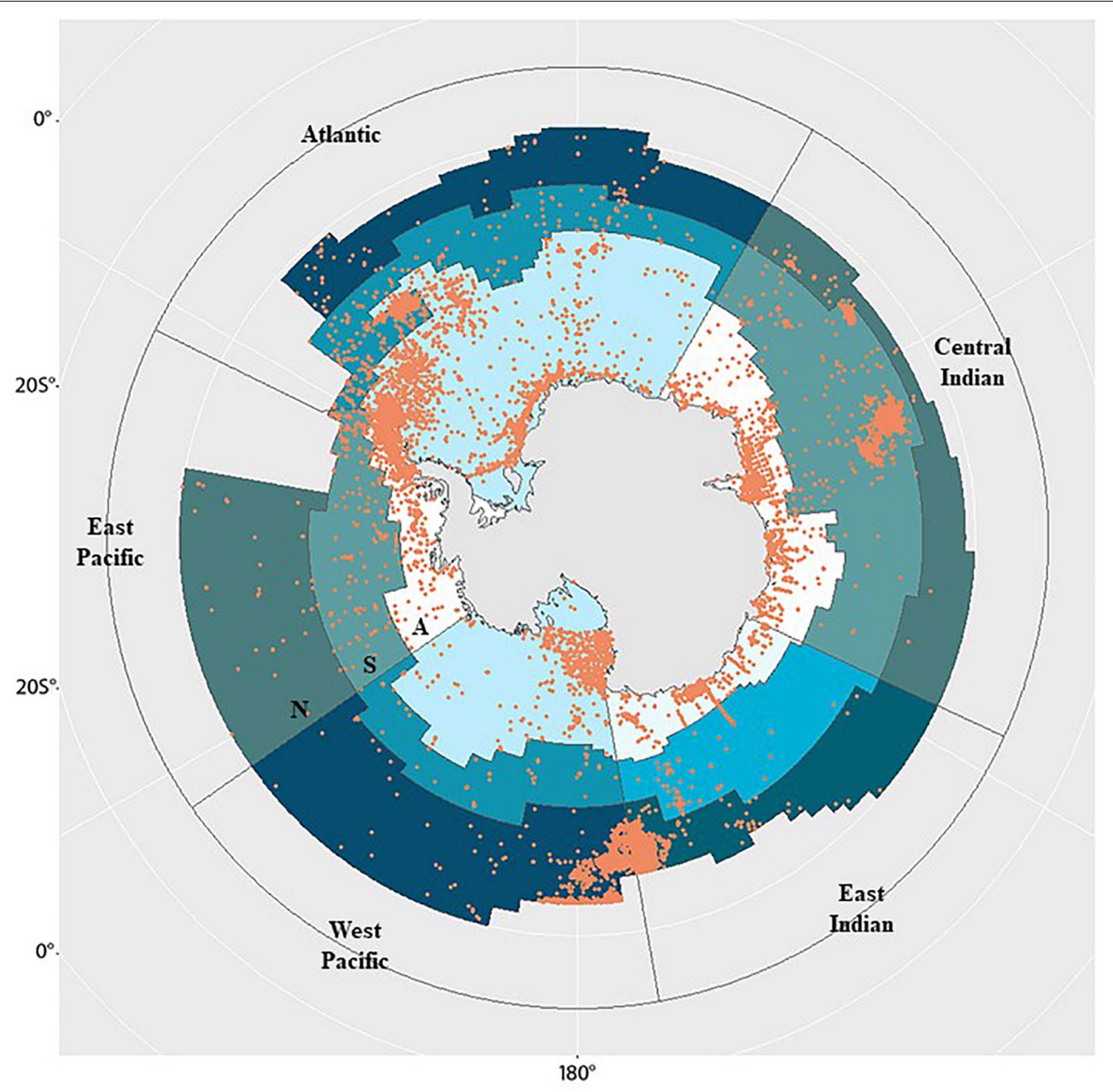

FIGURE 4 | The distribution of 161,711 distribution records (orange circles) belonging to 7,945 benthic species across size classes ( macro-, mega-, meio-fauna) extracted from Ocean Biogeographic Information System (OBIS) and Global Biodiversity Information Facility (GBIF). MEASO areas are shown including MEASO sectors (Atlantic, Central Indian, East Indian, West Pacific, East Pacific) and MEASO zones (where $N=$ northern, $S=$ subantarctic, $A=$ Antarctic). Details regarding data analyses are provided in Supplementary Information.

soft-substrates are also found in the Southern Ocean deep sea (Jones et al., 2007; Post et al., 2010; Brasier et al., 2018). Shallow water communities display high levels of heterogeneity associated with variation in habitat and sediments (Stark et al., 2003), and oceanographic processes including ice scour (Smale et al., 2008), sea ice cover and duration (Clark et al., 2013). For example, hard-substrate habitats in shallow coastal waters tend to display a gradient of benthic communities related to ice cover, whereby areas with less than 1-2 months open water per summer are dominated by marine invertebrates, while areas with longer periods of open water tend to be dominated by macroalgae (Clark et al., 2013, 2015).

In deeper water, slope and deep-sea communities are often characterized by a high number of species reaching peak diversity at lower bathyal and upper abyssal depths (Brandt et al., 2007; Menot et al., 2010). Highly specialized benthic fauna are associated with habitats such as hydrothermal vents systems, including the yeti crab Kiwa tyleri Thatje, 2015 (Figure 5) on the East Scotia Ridge vent field (Marsh et al., 2012; Rogers et al., 2012). Seamounts such as Maud Rise contain distinct faunal communities compared to nearby areas, and are characterized by a high abundance of the brooding gastropod Onoba subantarctica wilkesiana (Hedley, 1916), Haplomunnidae isopods and tubedwelling suspension feeding polychaetes (Brandt et al., 2011).

\section{RESPONSES AND PROGNOSES TO IMPACT DRIVERS OF CHANGE}

In this section, we evaluate how benthic species are expected to respond to changes in global and local drivers, and then assess the prognoses for benthos in relation to those drivers. 

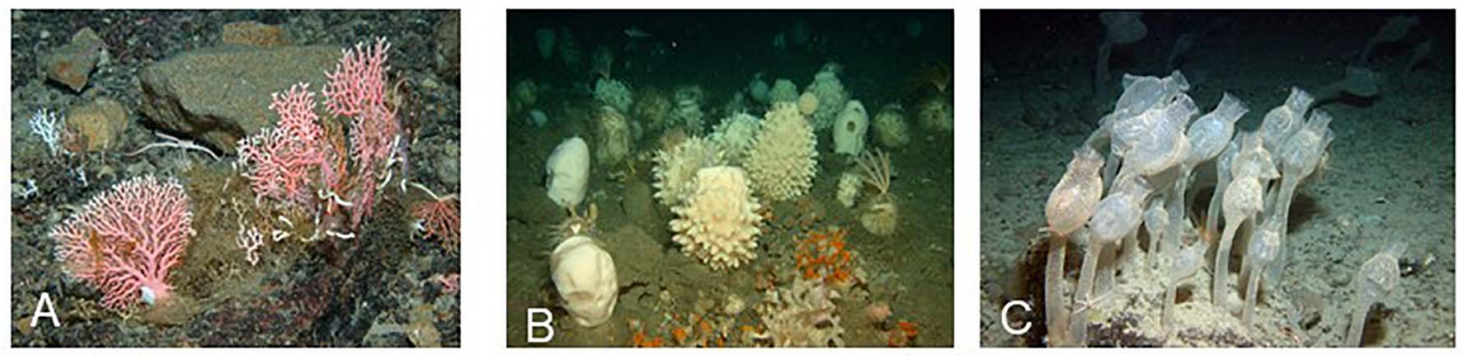

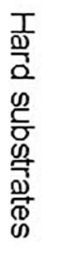
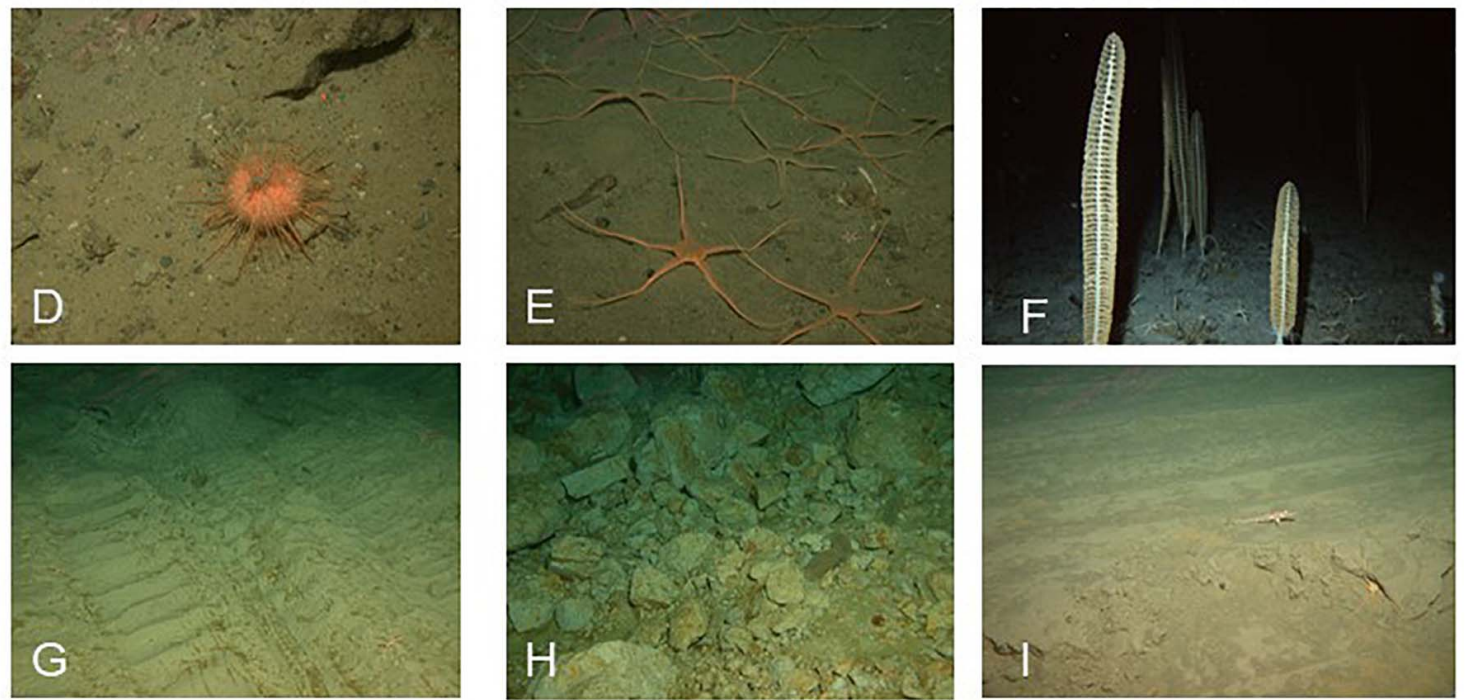

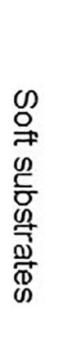
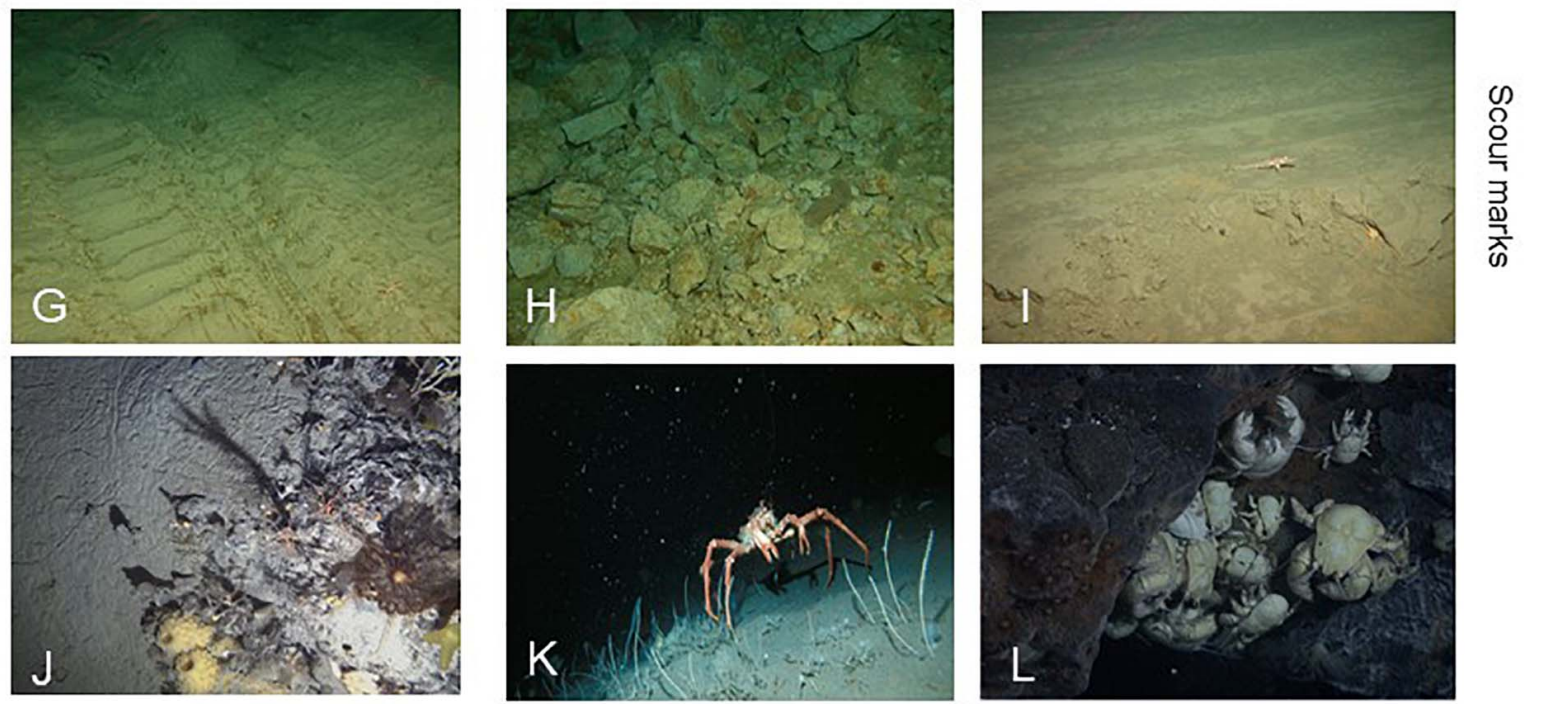

FIGURE 5 | Examples of different benthic habitats, species and scouring impacts. Where, first row = fauna associated with hard substrate on the Antarctic shelf including: $A=$ corals, $B=$ sponges, $C=$ sea squirts, second row = fauna associated with soft sediments on the Antarctic shelf where $D=$ sea urchin, $E=$ brittle stars, $\mathrm{F}=$ sea pens, third row = scour marks, fourth row, $\mathrm{J}=$ edge of retreating glacier Marian Cove (King George Island), $\mathrm{K}=\mathrm{spider} \mathrm{crab}, \mathrm{L}=\mathrm{yeti} \mathrm{crabs}$ at hydrothermal vents. Image sources: J. Gutt, A. Starmans, W. Dimmler, AWI, www.pangaea.de (A-I,K), Dave Barnes (J), NERC ChEsSo Consortium, Rogers et al. (2020) (L).

Responses presented include in situ observations and laboratory analyses, whilst our prognoses use evidence from the published literature, publicly available datasets, and fisheries data within the Commission for the Conservation of Antarctic Marine Living Resources (CCAMLR) to determine longer term change. Whilst we can not assess the outcomes of multiple simultaneous drivers we discuss the potential for cumulative impacts of multiple drivers on Southern Ocean benthic communities.

\section{Ocean Temperature \\ Responses}

As a consequence of evolving in the Southern Ocean, many benthic species are sensitive to small increases in temperature.
In the most comprehensive study to date, long-term lethal temperature limits for 14 benthic species were estimated in the laboratory to be between 1 and $6^{\circ} \mathrm{C}$ (Peck et al., 2009). However, the thermal limits for activity are often even less, for example only $2-3^{\circ} \mathrm{C}$ for turning over in the limpet Nacella concinna (Strebel, 1908) and burying in the clam Laternula elliptica (King, 1832; Peck et al., 2004; Morley et al., 2012a). Overall, temperature tolerance and plasticity is species specific, however recent studies have shown that few Antarctic benthic invertebrates can acclimate to temperatures of $6^{\circ} \mathrm{C}$ and may have long-term limits a few degrees warmer than this (Morley et al., 2019). Some species differ in thermal tolerance between geographic areas of the Southern Ocean (Morley et al., 2009). For example, the sea star Odontaster validus Koehler (1906), 
and the aforementioned clam L. elliptica in the Ross Sea had lower acute thermal limits than those in more northern areas on the Antarctic Peninsula (Morley et al., 2012b). Furthermore, L. elliptica has been found in intertidal habitats at James Ross Island at the northern end of the West Antarctic Peninsula, with ambient temperatures of $7.5^{\circ} \mathrm{C}$ within the sediment and $10^{\circ} \mathrm{C}$ air temperature (Waller et al., 2017b). More sensitive species, such as the Antarctic scallop, Adamussium colbecki (Smith, 1902) will only be able to survive if they can migrate to more southerly latitudes, or to depths below the warmer water masses (Peck et al., 2004). Other species, such as the aforementioned predatory sea star $O$. validus can continue feeding and turning over at temperatures up to $6^{\circ} \mathrm{C}$ (Peck et al., 2008). The differences in thermal tolerance and plasticity are likely to lead to both winners and losers, changing species distributions and therefore the composition of the benthic assemblage (Griffiths et al., 2017; Morley et al., 2019).

\section{Prognoses}

The impact of increasing ocean temperature will be population and species specific, due to both differences in thermal tolerance but also species' ability to take advantage of habitat that becomes available as the ice retreats (Morley et al., 2019).
Likely due to the glacial history of the Antarctic, with ice covering much of the shelf during ice ages, many Southern Ocean marine ectotherms are eurybathic. Non-native species are expected to migrate into the Southern Ocean and establish breeding populations (Hughes et al., 2020). Similarly, deepwater species, such as reptant decapod crustaceans, which are thought to be excluded from the coldest areas within the Southern Ocean (Hellberg et al., 2019), could move into shallower water as it warms (Aronson et al., 2007; Griffiths et al., 2013). Physiological research indicates some species may perform better under limited warming while others reach thermal limits and become less competitive (Morley et al., 2019; Figure 6). Under altered competition and changing species distributions there are likely to be alterations in trophic interactions, food webs and the dominant species within benthic communities (Box 1).

\section{Ice Shelf Disintegration, Increased Iceberg Scour, and Biogenic Flux} Responses

When ice shelves disintegrate, the ecological environment changes from allochthonous, where carbon must come from

\section{How will benthic communities of the Antarctic shelf respond?}

Antarctic benthic communities vary in their potential response to drivers of change. Here we represent the hypothesised individual impact of five prevalent drivers of change in the Antarctic region on seafloor communities.

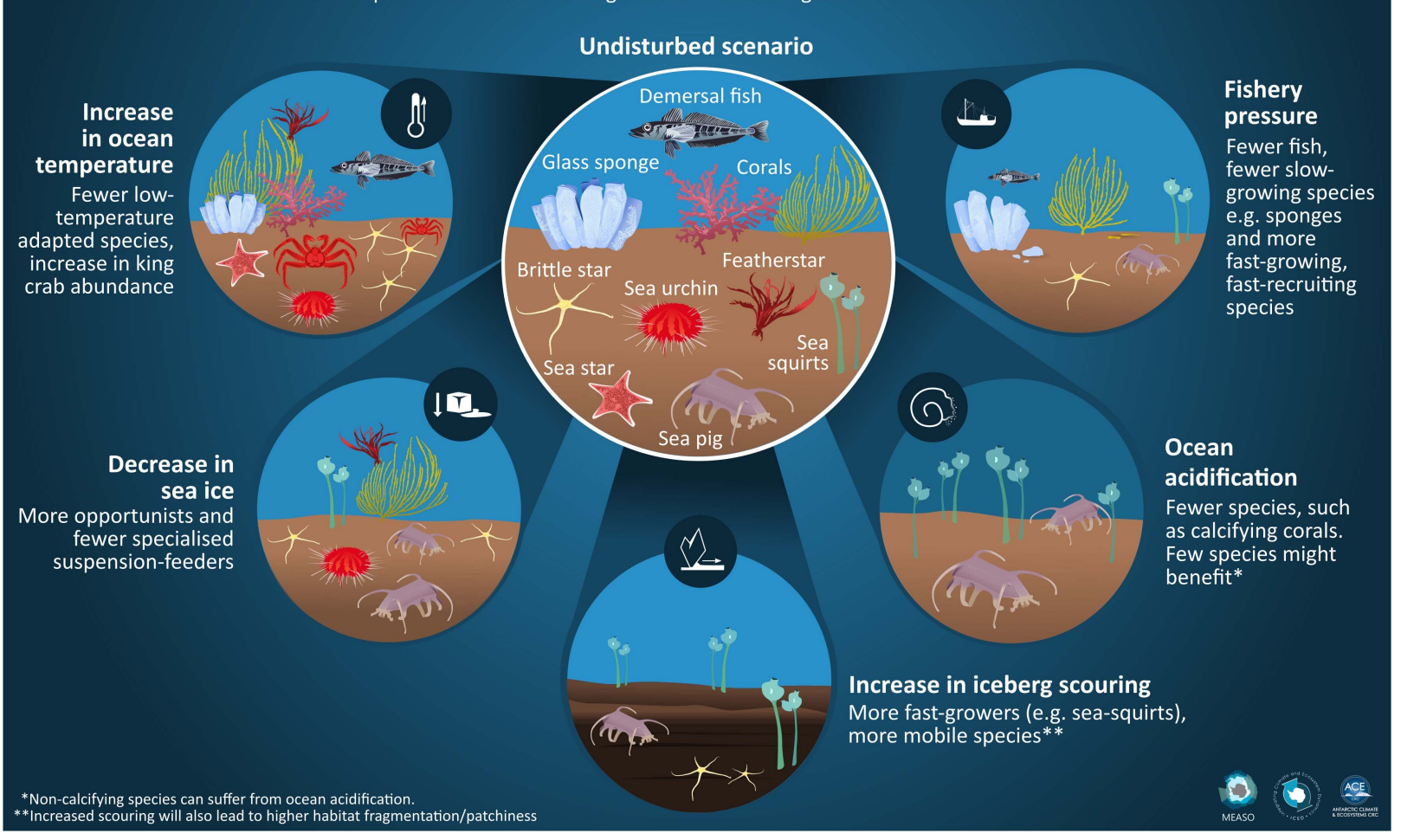

FIGURE 6 | Conceptual changes to an undisturbed seafloor community under five different impact drivers; increasing ocean temperature, decrease in sea ice, increase in iceberg scouring, ocean acidification and fishery pressure. 
BOX 1 | Research gaps and priorities.

\section{Data coverage}

Most Southern Ocean benthic data have been collected within $150 \mathrm{~km}$ of research stations, and very few long-term data sets existfor benthic communities and habitats. Regions such as those formerly covered by the Larsen A and B ice shelves and the Amundsen Sea (Pine Island Bay and the Thwaites Glacier regions), that are currently experiencing some of the most rapid oceanographic and glaciological changes, are among the most logistically difficult to study and have only been sampled by a handful of expeditions. This leaves us with some of the most impacted areas having little baseline data for comparison.

Data sharing of both newly acquired and archived data is vital to improve spatial and temporal coverage for circumpolar assessments. Key databases include the Ocean Biogeographic Information System (OBIS, https://obis.org/about/) and the Global Biodiversity Information Facility (GBIF, https://www.gbif.org/). Both OBIS and GBIF allow their data to be used by different gateways and repositories such as SCAR Antarctic Biodiversity Portal (the Antarctic regional Node of both OBIS and GBIF), the Register of Antarctic Species (RAS, http://ras.biodiversity.aq/), CCAMLR Geographical Information System (https://www.ccamlr.org/en/data/online-gis), and Southern Ocean interactive map (SOOSmap https://www.scar.org/data-products/soosmap/).

\section{Knowledge gaps and projections of future change}

Among the key limiting factors when projecting change within the Southern Ocean benthos are ecological variation and species-specific responses to different drivers (e.g., temperature and ocean acidification). Understanding the environmental tolerances of Southern Ocean species will enable monitoring of critical thresholds or tipping points in environmental parameters (e.g., Clark et al., 2013; Gutt et al., 2018). This, in turn, will help us understand the role of diversity in benthic resilience and vulnerability to change (Baggini et al., 2015; Dayton et al., 2016; Douglas et al., 2017). The observed environmental envelope of species and communities can be estimated to a certain extent based on historical observations, as demonstrated by Griffiths et al. (2017) in gaging the thermal tolerances of Southern Ocean species. However, realized responses to drivers may be more complex than isolated species envelopes due to competitive interactions between species within assemblages (Barnes et al., 2021).

Ongoing environmental observations and the growing capacity of the Southern Ocean Observing System to monitor oceanographic parameters such as sea ice, biogeochemical parameters, and biological variables (Newman et al., 2019) allow researchers to identify hotspots of change. However, they must be combined with biological observations to track (e.g., Gutt et al., 2011; Fillinger et al., 2013) or project (Griffiths et al., 2017; Fabri-Ruiz et al., 2020) impacts upon benthic communities. For example, Jansen et al. (2018) mapped predicted changes in food supply from surface waters to the benthos following ice-scape changes in the Mertz polynya region. They found significant changes in local oceanography and surface production, which influenced patterns of predicted seafloor food availability hundreds of kilometers from the calved glacier tongue,impacting the modeled distribution of suspension-feeder communities. Integrating this type of approach with information about benthic ecosystem structure and a better understanding of the system can highlight not only where changes are happening, but also indicate how community composition might change (Jansen et al., 2019).

\section{Identification and management of current and future risks}

Marine protected areas (MPAs) are the most significant conservation strategy under consideration in Commission for the Conservation of Antarctic Marine Living Resources (CCAMLR). Vulnerable marine ecosystem thresholds, a method used to assess benthic habitat prioritization for protection, are also under consideration. However, the current weight-based thresholds are strongly biased toward sponge-dominated communities and thus may underestimate other vulnerable groups such as diverse coral communities. A re-examination of vulnerability traits is needed and other thresholds such as diversity indices or lower weight thresholds for overlooked taxa need to be considered.

Models can and are being used in Southern Ocean management (Welsford et al., 2014). Usage includes the assessment of current and proposed MPAs or networks under future scenarios; these models can be used in a robust and reproducible way and updated as new data become available (Fabri-Ruiz et al., 2020). Discussion between researchers and policy makers is needed to determine appropriate scales to inform marine conservation and management of marine living resources (Kennicutt et al., 2014; Gutt et al., 2019). Not only should these models incorporate the relevant global and local drivers discussed here and other recent syntheses (see Gutt et al., 2020), but benthic models also need to represent fine-scale patchiness and broadscale differences in community composition, as well as regional connectivity (e.g., Thrush et al., 2006; Gutt et al., 2019; Robinson et al., 2020; see Weldrick et al. to be published in this research topic).

Tourism and shipping impacts on benthic communities are currently overlooked. Investigation is required into the distribution and level of activities that make contact with the seabed (e.g., anchors, submersible, and diving) to date. Once Antarctic tourism recovers from the COVID-19 pandemic, additional measures may be needed to minimize their impact.

elsewhere, to autochthonous, where carbon is now fixed locally because light is accessible in the water column, thereby driving local primary production. This algal growth increases the food available for higher trophic levels and is exported to the benthic system, creating a new carbon sink and a possible negative feedback to climate change (Bertolin and Schloss, 2009; Peck et al., 2010; Barnes et al., 2018). However, intense phytoplankton blooms do not always occur in areas where ice shelves have disintegrated, as primary productivity also depends on the degree of permanent or seasonal sea ice cover (Cape et al., 2014; Morley et al., 2020).

Researchers investigated benthic sites that were once under the Larsen A and B ice shelves, which collapsed in 1995 and 2002, respectively (Hauquier et al., 2011; Gutt et al., 2013; Hauquier et al., 2016). Approximately five years following the collapse, the Larsen A site consisted of ascidians that had settled and grown in large numbers. Within the subsequent 12 to 16-year period of faunistic succession, most ascidians disappeared, and formerly rare species increased in abundance. Whilst suspension feeding ophiuroids halved in abundance, local populations of deposit feeding species increased (Gutt et al., 2013). A detailed discussion of ecological responses to ice shelf loss is presented in Ingels et al. (2020), including shifting food regimes associated with modified phytodetrital inputs. The retreat of glacier tongues, long and narrow sheets of ice that project out from the coastline, may also have similar benthic effects to ice-shelf disintegration. For example, around the MertzGlacier Tongue in East Antarctica models have predicted an increase in suspension feeder abundances "fueled by increased food supply" (Jansen et al., 2018). 
Sediments in sub-ice shelf environments are typically characterized by low depositional rates. The collapse of ice shelves around the Antarctic Peninsula during the 1990s and early 2000s revealed the nature of sediments deposited beneath the ice shelves, and changes in sedimentation during and since collapse. Increased calving of icebergs at the seaward limit of ice shelves causes increased deposition of coarse sediments from ice-rafted debris (Domack et al., 1998). In addition, collapse of the Larsen A Ice Shelf caused large phytoplankton blooms in newly icefree areas (Bertolin and Schloss, 2009), altering the deposition of phytodetritus to the seafloor (Domack et al., 2005a; Sañé et al., 2013). The increased sediment flux to the seafloor in these newly exposed areas can impact seafloor communities by providing an enhanced food source and smothering or burying existing communities. For example, suspension feeders can be excluded in areas with high sedimentation rates due to clogging of their filter-feeding structures (Pasotti et al., 2014). Disintegration of ice shelves that receive little inflow from open waters can radically change the productivity of the system and hence the seafloor ecosystem. Following the collapse of the Larsen A Ice Shelf, the flux of organic matter to the seafloor increased dramatically and resulted in a rapid growth in hexactinellid sponge biomass and abundance (Fillinger et al., 2013); researchers also recorded an increase in other species typically considered early colonizers in the recently ice-free areas of the Larsen A and B Ice Shelves (Gutt et al., 2011).

Following the collapse of the Larsen B Ice Shelf, researchers discovered a chemotrophic ecosystem $100 \mathrm{~km}$ from the former ice shelf front (Domack et al., 2005b; Niemann et al., 2009). The very low marine sedimentation in this sub-ice shelf environment most likely contributed to the development of this chemotrophic community by excluding competition from marine biota typical of open-water environments. Within three years of the Larsen B Ice Shelf collapse, increased deposition of phytodetritus and ice-rafted debris caused significant change to the chemosynthetic ecosystem, reducing the extent of microbial mats through partial burial and allowing colonization by benthic grazers and higherlevel predators typical of Southern Ocean environments.

A consequence of increased ice shelf breakup or calving is an increase in the presence of icebergs. When icebergs drift in the open ocean they can locally fertilize the phytoplankton by releasing essential nutrients (Smith et al., 2013; Duprat et al., 2016) and stabilize the upper-water column through the local addition of freshwater (Smith et al., 2013). These processes facilitate algal growth, especially of diatoms, and contribute food to grazers such as krill (Vernet et al., 2011), which may increase storage of organic carbon (Trebilco et al., 2020). Ice scouring occurs when drifting ice, such as icebergs, contact the seafloor and will either continue drifting whilst in contact with the seabed or run aground until they are dislodged or disintegrate. The occurrence and distribution of scouring events are dependent on the rate of iceberg production, iceberg size (particularly the draught and keel), drift pathways and speed of movement (which can be influenced by oceanography and wind patterns) and melt rate (Dowdeswell and Bamber, 2007). Iceberg scour usually impacts the benthos to approximately $300 \mathrm{~m}$ on the shelf and effectively devastates almost all macrobenthos (Gutt et al., 2011) by direct mechanical force or indirect changes in hydrodynamic turbulence and local current patterns (Seiler and Gutt, 2007). Thus, calving, scouring and grounding often result in an immediate decline in species richness and abundances of benthic macrofaunal species (Thrush and Cummings, 2011).

Post-scouring recovery rates can be variable depending on local environmental conditions and oceanography, as well as a species' ability to relocate or settle via individual movement, advection by local currents or larval recolonization (Peck et al., 1999). Generally, scouring results in an initial increase in pioneer species including echinoid, polychaete, isopod and gastropod species, followed by successional changes resulting after 12 months in a benthic community comparable to predisturbed or reference communities in shallow water $(<100 \mathrm{~m})$ (Smale et al., 2008). While a patchwork of different successional stages with different pioneer species, e.g., ascidians, cnidarians and exceptionally fast-growing sponges, can lead to high betadiversity (Gutt and Piepenburg, 2003), locally, intermediate stages of recolonization might also reach a structural maximum of diversity (Teixidó et al., 2004). Recently published data in, Zwerschke et al. (2021) found that it took a decade for a shallow water assemblage to 'bounce back' from major disturbance, which was only detectable with two decades of monitoring. In depths greater than $100 \mathrm{~m}$ succession toward a climax shelf community might require centuries due to the slow growth of adult habitatforming species (Gutt and Starmans, 2001).

The increased frequency of iceberg scouring in the West Antarctic Peninsula region reduces the chance of such species reaching sexual maturity in between scouring events and the increased mortality of both pioneer species and climax species threatens local biodiversity (Barnes and Souster, 2011; Barnes et al., 2014). By contrast, scouring at McMurdo Sound in the East-Pacific sector has increased biodiversity following mass recruitment and the fast growth of 12 sponge species; this is possibly supported by additional environmental factors such as an increase in the size of food particles that benefit sponges (Dayton et al., 2016, 2019; Kim et al., 2019). In fact, some suspension feeders not directly hit by icebergs can benefit from scouring by gaining extra food from resuspended material (Peck et al., 2005).

In addition to direct impacts, icebergs sometimes release large dropstones as they melt, distributing additional hard substrates across the seafloor. Dropstones from previous calving episodes (e.g., during the past deglaciation) have been shown to provide habitat for sessile invertebrates in both the Antarctic and the Arctic (Starmans et al., 1999; Schulz et al., 2010). Dropstones can be associated with significant increases in the abundance and diversity of taxa (Ziegler et al., 2017) and could promote increased settlement of sessile invertebrates across areas of otherwise soft substrate (Dayton, 1990; Post et al., 2017).

\section{Prognoses}

Under ongoing climate change and increasing loss of ice shelves, we envisage two potential scenarios: (1) the ecosystem will become locally more dynamic due to higher iceberg calving rates or ongoing collapses of entire ice shelves and shorter periods 
of solid ice cover; (2) a reduction in the number of icebergs as calving rates will regionally decrease since most ice shelves have disintegrated already and glaciers no longer reach the coast. The timing of these two scenarios is dependent on the intensity of future climate change and regional conditions, such as presence of ice shelves, and iceberg trajectories around the continent.

In the first scenario, elevated calving rates from ice shelves result in an increase in areas experiencing substantial ecological changes. In such areas, communities have locally reduced biomass and diversity, as well as low metabolic rates, but unique species composition (Gutt et al., 2011). Smaller areas where ice is grounded become exposed for the first time in decades to millennia for a variety of pelagic and benthic colonization (Lagger et al., 2017). It can be expected that original benthic communities under ice shelves, if they existed at all, were adapted to oligotrophic (nutrient-poor) conditions. These would be replaced by "normal" Southern Ocean shelf communities, e.g., an increased abundance of suspension feeders, following in situ primary production and local food supply to the seafloor. The increase in benthic biomass (Jones et al., 2014) contributes to global carbon storage and ultimately sequestration (Peck et al., 2010; Barnes et al., 2018). If a noticeable proportion of this additional biomass is buried in the sediment and not recycled in the water column to nutrients, such areas, e.g., newly emerging fjords (Barnes et al., 2020), will serve as true carbon sinks for long time scales (100-1000s of years).

An increase in floating icebergs in Southern Ocean shelf waters could lead to increased scouring events, resulting in a greater area of devastation of benthos. Subsequent recolonization develops a mosaic of patches of successional stages and leads to higher regional diversity until a certain level of disturbance magnitude is reached (Potthoff et al., 2006; Johst et al., 2006). As a result of increased iceberg calving, deposition of dropstones could increase hard substrate on the seafloor and thus could increase colonization by sessile filter-feeders and local patchiness within the benthos. However, the higher deposition of finegrained sediments may also affect the success of filter feeders (Pasotti et al., 2014).

It is of paramount interest to know which areas and habitats of the Antarctic shelf are most at risk. The frequency and location of scouring will be influenced by seasonal sea ice duration (effecting iceberg movement) and iceberg abundance, which is dependent on regional and local calving rates, as well as their movement and pathways. It can be expected that iceberg-disturbance rates will increase in areas downstream of disintegrating ice shelves and glaciers (see next section) for months or years after collapse (Gutt et al., 2011). However, the movement and pathways of icebergs can be influenced by many factors, including the properties of the iceberg (size, draught, mass, structure etc.), oceanographic factors such as tides, wind, sea ice and currents, as well as the depth and geomorphology of the underlying seafloor. It is predicted that certain geomorphic features such as shelf banks (see descriptions of geomorphic features in Supplementary Information) are more likely to be struck by icebergs (Barnes et al., 2018). Whilst iceberg distribution is highly patchy, grounding hotspots have been identified for giant icebergs $\left(>30 \mathrm{~km}^{2}\right)$ in the East Pacific, Atlantic, and Central Indian MEASO sectors (Barnes et al., 2018).
In the second scenario, with fewer icebergs the benthos is likely to experience less scouring which could result in reduced diversity. This is based on the "Intermediate-Disturbance Hypothesis" whereby moderate iceberg scouring enables higher benthic diversity and thus without these disturbances reduced diversity could be expected (Johst et al., 2006). Gutt and Piepenburg (2003), for example, recorded lower regional habitat heterogeneity and benthic diversity in areas of the Weddell Sea where little scouring had occurred. In the Arctic, Laudien et al. (2007) observed less diverse benthic communities at depths of low scouring impact. Without disturbance colonizing species may only exist in refuge areas as they are otherwise outcompeted by "mature" benthic fauna such as sponges.

\section{Glacial Retreat, Sedimentation, and Newly Ice-Free Habitats Responses}

Rapid regional warming around Antarctica has driven the retreat of many tidewater glaciers which can have direct and cascading effects on surrounding ecosystems (Cook et al., 2005). Those likely to impact benthic communities can include potential ice scour, increased sedimentation rates, and the availability of newly ice-free habitats (Sahade et al., 2015).

Several studies have observed faunistic succession following glacial retreat. For example, early observations of the retreating tidewater glacier front at Anvers Island (West Antarctic Peninsula) showed high dominance of only one polychaete species near the glacier cliff in 1971 presumably due to its high stress tolerance. Within the next 18 years after the initial survey, abundances of benthic organisms showed an increase of up to a factor of 5.5 and the number of taxa doubled (Hyland et al., 1994). In newly ice-free soft bottoms in Potter Cove, King George Island at the northern tip of the West Antarctic Peninsula, sediment runoff caused by the retreating glacier was likely the main driver of a shift from an ascidianmacroalgae dominant community to a mixed assemblage (including sponges, cnidarians, ascidians and ophiuroids), with lower abundances but higher species diversity (Sahade et al., 2015). Where glacial retreat has led to new ice-free areas, the shift has resulted in macroalgal colonization of benthic habitats on the West Antarctic Peninsula (Quartino et al., 2013). However, with increased run-off reducing the depth of underwater photosynthetically active radiation, the lower depth distribution of some macroalgae species may be reduced (Deregibus et al., 2016).

As glaciers retreat plumes of sediment-laden meltwaters and terrestrial runoff can enter the marine environment, an effect that has also been observed in Arctic environments (e.g., Węsławski et al., 2011). This increased sedimentation leads to higher levels of water-column turbidity, increased rates of inorganic sedimentation and relatively low organic matter deposition (Węsławski et al., 2011). In addition, the increased turbidity of the water-column inhibits phytoplankton production, while higher sedimentation rates cause burial of some seafloor organisms. Higher rates of sedimentation have also been found to favor small-bodied, mobile surface deposit 
feeders, causing low macrobenthic biomass and diversity (e.g., King George Island, West Antarctic Peninsula - Pabis et al., 2011; Siciński et al., 2012; parts of the Arctic - WlodarskaKowalczuk et al., 2005). Suspension feeders are typically absent in areas with high sediment loads due to clogging of their filter structures (Pasotti et al., 2014). However, it is difficult to generalize impacts between different systems. Some parts of King George Island, for instance, have responded to increased sedimentation with a shift to a more mixed benthic assemblage, highlighting differing tolerances to sediment input (Sahade et al., 2015) and the varied response to a complex array of additional variables (Pasotti et al., 2014).

\section{Prognoses}

Some shallow water marine invertebrates may be at risk of local extinction, including filter-feeding sponges, bryozoans, tunicates, corals and tube building polychaetes, all of which perform vital ecosystem functions such as water filtration, nutrient recycling and trophic transfer. Such localized impacts can be through intense local scouring (Barnes and Souster, 2011), increased sedimentation (Sahade et al., 2015), new invading nonindigenous species (Cárdenas et al., 2020) or potentially extreme warming spikes in the future. These fauna are critical components of the coastal food web, with links to pelagic and shelf ecosystems (Reid and Croxall, 2001). Future ecosystem change is likely to drive endemic shallow Southern Ocean invertebrate communities into ever shrinking refugia where longer periods of sea ice duration are maintained, further fragmenting populations and impeding genetic connectivity (Fahrig, 2003). Deep-water refugia may exist for some species on the Antarctic shelf where there is low light irrespective of sea ice, the unique invertebrate communities found under sea ice in shallow water will become threatened as periods of sea ice duration shorten.

As glaciers retreat onto land, exposing the valley floor, Arctic examples suggest that sediment discharge is captured increasingly on land, reducing turbidity to the nearshore water column (Syvitski et al., 1989). This enhances light penetration and reduces smothering of seafloor communities, these conditions can promote the development of a diverse benthic community. Insight from studies within glacio-marine fjords (fjords with tidewater glaciers) of the West Antarctic Peninsula found greater benthic megafaunal abundance within the fjord basin than control sites on the nearby open shelf (Grange and Smith, 2013). This result could be a consequence of weak meltwater influences, low sedimentation, and high food inputs during the early stages of climate warming. However, increased sediment loading to steep nearshore slopes may generate sediment slumping, contributing to longer-term smothering of benthic organisms across broader areas (Smale and Barnes, 2008).

\section{Sea Ice Change, Light, and Primary Production \\ Responses}

Sea ice extent varies seasonally and regionally and, within the last decade (2010-2020) there have been significant changes in Antarctic sea ice distribution; for more details see Morley et al. (2020) in this research topic. To date, due to the extreme seasonality of sea ice cover, most benthic habitats on the Antarctic shelf receive a short and intense pulse of organic material from the surface waters (Smith et al., 2006, 2012). This exchange of organic material between the pelagic and benthic zones may also be referred to as bentho-pelagic coupling. Changes to sea ice can impact the benthic habitats via altered light regimes, primary production and export to the benthos (e.g., Clark et al., 2013; Barnes, 2015). Altered light regimes such as an increased duration of photosynthetic active radiation penetrating the water column can affect the timing, intensity and duration of primary production and macroalgae on the seafloor (Vernet et al., 2008; McMinn et al., 2010).

Increased seasonal sea ice loss around Antarctica has resulted in extended phytoplankton blooms and increased export to, and production by the benthos (Arrigo et al., 2008; Barnes, 2015). Long-term studies along the West Antarctic Peninsula have also shown a change in the mean size of phytoplankton, indicating a decrease in larger phytoplankton, such as diatoms, and an increase in smaller phytoplankton, such as ciliates and flagellates, over the continental shelf of the West Antarctic Peninsula (Rogers et al., 2020). Smaller phytoplankton are important for many suspension-feeding benthic species as they are easier to consume and break down (Barnes, 2017a). At McMurdo Sound similar long-term studies observed a regime shift from large to small-sized food particles consistent with increased recruitment and growth of filter-feeding organisms and reduced populations of those that favor large particles, such as echinoderms, bivalves, crinoids (Dayton et al., 2019).

As discussed with the loss of ice shelves, detecting benthic change in response to sea ice changes is difficult because it is so variable in time and space. Increased annual growth has been detected in some suspension feeders in the Ross Sea, driven by wind strengthening creating and maintaining open-water polynyas, and in turn influencing primary production (Arrigo et al., 2008; Barnes et al., 2011). Around the West Antarctic this may have doubled benthic growth, and consequently carbon storage, on the seafloor in the last 25 years, again coincident with sea ice reduction (Barnes, 2015). However, similar losses of sea ice nearshore can increase scouring by icebergs, potentially wiping out growth and carbon gains (from longer access to phytoplankton food) and suspending the shallows in an early state of succession dominated by pioneer species (Barnes and Souster, 2011). Predicting total carbon storage of the Southern Ocean benthos is complex. Annual carbon production has been measured at well-studied sites within the Weddell Sea, West Antarctic Peninsula, Amundsen Sea, Ross Sea, South Orkney Islands and at South Georgia (Barnes, 2015). When up-scaled to the entire area of the Antarctic shelf $\left(4.4 \times 106 \mathrm{~km}^{2}\right)$, zoobenthic annual carbon production is estimated between 30 and $80 \mathrm{MtCyr}^{-1}$, depending on ice shelf losses, new growth and iceberg scouring (Barnes, 2017a, Barnes et al., 2018); this value is less than $1 \%$ of annual anthropogenic carbon emissions (IPCC, 2014). Antarctic blue carbon sequestered in the benthos around the continental shelf has an estimated economic

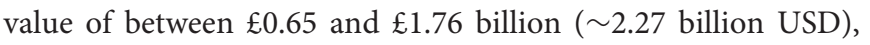
however the true value is in conserving ecosystem services and a natural negative feedback to climate change (Barnes et al., 2018; Bax et al., 2021). 


\section{Prognosis}

The interaction between changing sea-ice duration and solar irradiance renders polar coastal ecosystems vulnerable to relatively rapid change. Recent changes in ice and snow cover have already altered models of annual light budgets for large areas of the Arctic and Antarctic and further predicted changes in sea-ice cover are likely to result in significant increases in photosynthetically active radiation (Clark et al., 2013). Ecological regime shifts have been observed in the Arctic (Svalbard), where rocky-reef habitats were rapidly invaded by macroalgae over a period of gradual sea-ice reduction (Kortsch et al., 2012). Increasing seawater temperatures have also been indicated as contributing to expansion of macroalgal habitats in Arctic regions, however changes in photosynthetic active radiation through decreases in sea ice cover have been identified as the primary driver in mechanistic models (Scherrer et al., 2019).

Possible shifts from invertebrate- to algal-dominated states resulting from increases in light could reduce coastal biodiversity in some Southern Ocean locations (Clark et al., 2013), and lead to alterations in ecosystem function (Worm et al., 2006; Cavanagh et al., 2020). However, the spatial variation in the duration of Antarctic sea ice cover (1979-2010) around the Antarctic margin (Maksym et al., 2012), combined with a lack of observations at appropriate spatial and temporal scales in Southern Ocean waters, prohibit drawing conclusions about changes in algal distribution.

\section{Ocean Acidification \\ Responses}

The process of ocean acidification within the Southern Ocean may lead to the increased dissolution of the calcium-carbonate skeletons and shells built by calcified benthic species (Fabry, 2008). In particular, skeletons/shells are composed of calciumcarbonate minerals, calcite or aragonite, and calcite can also contain varying levels of magnesium $(\mathrm{Mg})$ which alters its solubility. Knowing the skeletal mineralogy of Southern Ocean calcifiers is thus essential to better understanding the vulnerability of each species to dissolution. There is a growing interest in assessing mineralogical changes in Southern Ocean taxa as a response to environmental parameters, but it is still limited to few groups (Borisenko and Gontar, 1991; McClintock et al., 2009, 2011; Taylor et al., 2009; Loxton et al., 2014; Figuerola et al., 2015, 2019; Hancock et al., 2020; Figuerola et al., 2021). The historical spatial and temporal distribution of Southern Ocean calcifiers can be also indicative of species resilience to changing ocean chemistry. For example, Margolin et al. (2014) investigated the spatial and temporal distribution of the solitary scleractinian corals within the Drake Passage from the last 35,000 years and recorded differences in age and depth distributions across taxa that could be linked to changes in carbonate saturation state, surface productivity and subsurface oxygen concentrations. The synergistic interactions between common variables recorded in these paleo-oceanographic studies hamper our ability to understand past ecosystem succession in response to decreasing saturation states (Coggon et al., 2010).
Experimental studies on benthic calcifiers in the Southern Ocean are few, and show contrasting results, which likely indicates species-specific responses to lowering $\mathrm{pH}$ levels. Important life processes of some benthic calcifiers appear to be resilient to $\mathrm{pH}$ lowering, including the physiology, growth and escape responses in gastropods (Schram et al., 2014; Zhang et al., 2016); shell crystal deposition and robustness in the scallop A. colbecki (Dell'Acqua et al., 2019); development and feeding energetics of the sea urchin Sterechinus neumayeri (Meissner, 1900; Clark et al., 2009; Morley et al., 2016; Karelitz et al., 2017); and continued shell growth and repair in brachiopods (Cross et al., 2015). Ocean acidification has been found to impact some calcifying organisms' early-life stages, reproduction and overall function, which has been recorded in sea stars (Gonzalez-Bernat et al., 2013), sea urchins (Clark et al., 2009; Foo et al., 2016), gastropods (Schram et al., 2016), and bivalves (Cummings et al., 2011).

\section{Prognoses}

The depth of the present-day Aragonite and Calcite Saturation Horizon exceeds 1,000 and 2,000 m across most of the Southern Ocean, respectively (Negrete-García et al., 2019). However, the surface is predicted to be undersaturated with respect to aragonite by the end of this century, altering its biochemistry (Orr et al., 2005; Hauri et al., 2016; Negrete-García et al., 2019). Species with aragonitic shells such as the bivalve L. elliptica (Bylenga et al., 2015, 2017) and high-magnesium calcite skeletons such as the sea star Glabraster antarctica (Smith, 1876), the bryozoan Beania erecta Waters, 1904, some spirorbid species (McClintock et al., 2011; Figuerola et al., 2019), and corals (Bax, 2014; Bax and Cairns, 2014), could be particularly vulnerable to global ocean surface $\mathrm{pH}$ reductions of 0.3-0.5 units by the year 2100 (Caldeira and Wickett, 2005). Sea stars and brittle stars are likely to be the first echinoderms to be affected by near-term ocean acidification (McClintock et al., 2011; Figure 6). However, species-specific mechanisms should be also taken into account in order to evaluate their vulnerability. For example, some stylasterid coral species exhibit mineralogical plasticity, whereby their skeletons contain calcite, aragonite or a mixture of the two polymorphs (Cairns and Macintyre, 1992). This mineralogical plasticity modifies the energetic cost of calcification and has been proposed as a compensatory mechanism to the lowering of $\mathrm{pH}$ in the oceans for calcifying organisms (Leung et al., 2017) and has been found to occur in brachiopods (Cross et al., 2019), and benthic bivalves (Cummings et al., 2011), likely improving their resilience to ocean acidification. Other species such as sea urchins and some molluscan species have external organic layers to protect skeletons/shells from ambient seawater (Ries et al., 2009). Some calcifying organisms have non-calcifying embryonic stages, and in some species, these larvae could be more robust to ocean acidification (Byrne, 2011). However, more work needs to be undertaken to understand the susceptibility of Southern Ocean species to ocean acidification.

To improve our predictions of the effects of ocean acidification on benthic calcifiers the factors that influence their vulnerability must be considered. These can include local seasonal and spatial variability in ocean chemistry, combined and interacting effects 
(e.g., ocean warming), species-specific skeletal mineralogies, biological traits, physiological processes and compensation strategies (Figuerola et al., 2021). A recent literature review and meta-analysis illustrates that the response variation is largely dependent on mineralogical composition, with calcitic, aragonitic and high-magnesium calcite skeletons more vulnerable than low-magnesium calcite to future predicted carbonate chemistry conditions (Figuerola et al., 2021). Further investigation is needed to confirm these emerging trends.

Depending on acclimation time, the metabolic and reproductive physiology can be improved in certain animals, such as sea urchins (Suckling et al., 2015). For non-calcifying organisms such as multicellular algae, ocean acidification may increase production and growth (Andersson et al., 2011). This could mean the potential shift of calcifying habitat-forming organisms to macroalgae in shallow Antarctic and subantarctic coastal benthic environments, due to larval, reproductive and embryonic $\mathrm{pH}$ sensitivity of many calcifying organisms.

The consequences of ocean acidification over longer time scales, i.e., by 2100 , are unknown. As oceanic $\mathrm{pH}$ decreases, the depth of the saturation horizon in the water column becomes shallower, changing the range and composition of deep-sea ecosystems (Orr et al., 2005). Guinotte and Fabry (2008) suggest the aragonite saturation horizon, which is currently estimated at $\sim 1000 \mathrm{~m}$ (Feely et al., 2004), may rise to surface waters in the Southern Ocean by 2100 . The anticipated shoaling of the carbonate compensation depth could reduce the deepest depths of calcifying organisms, such as corals, and these organisms may have to "emerge" to shallower depths. Experimental results indicate that calcifying organisms do not readily acclimatize to decreasing carbonate saturation states (Orr et al., 2005; Guinotte and Fabry, 2008). Further in situ studies, such as using free-ocean $\mathrm{CO}_{2}$ enrichment (FOCE) systems (e.g. Stark et al., 2019), may allow us to evaluate longer term effects of ocean acidification. However, if a lack of acclimation holds true under natural conditions, the geographical range and abundance of some calcifying species may be reduced whilst others become extinct. For more details regarding seasonal variability in $\mathrm{pH}$ across the Southern Ocean and how this may affect a species capacity to cope with changing ocean acidity see Morley et al. (2020), in this research topic.

\section{Fishing}

All commercial fishing operations in the Southern Ocean have been regulated by CCAMLR since 1982, before which substantial overfishing had occurred over the 1970s (Kock, 1992; Caccavo et al., to be published in this research topic) (Figure 7). Effective regulation did not begin until the late 1980s, with catch limits determined by assessments and decision rules coming in to play in the mid-1990s (Constable et al., 2000; Constable, 2011). Currently, the fisheries that impact benthic communities are bottom trawling for mackerel icefish (Champsocephalus gunnari, Lönnberg, 1905) and toothfish (Dissostichus eleginoides, Smitt, 1898) around Heard and McDonald Islands and toothfish fisheries (Dissostichus spp.) using long-lines and sometimes pots/traps. There have also been crab fisheries (e.g., for Paralomas spp. in South Georgia and the South Orkneys) that used pots or traps that interacted with the benthos, but to date these have been short-lived and sporadic.

\section{Responses}

The potential effects of fishing activity on seabed communities include physical damage and breakage to invertebrate fauna, scouring and structural damage to sediments and smothering of sessile fauna via sediment resuspension (Welsford et al., 2014); these impacts can be equated to iceberg scour but in deeper water (trawling occurs to about $1000 \mathrm{~m}$ depth while longlining can be as deep as $2000 \mathrm{~m}$ deep). Trawling has been the most significantly detrimental method of fishing to benthic communities globally (UNEP, 2006). In the Southern Ocean, fishing for toothfish in waters shallower than $550 \mathrm{~m}$ has been prohibited by a CCAMLR Conservation Measure since 2009 (CCAMLR, 2009a; Jones et al., 2016). Commercial bottom trawling in high seas areas is also restricted within the CCAMLR Convention Area (CCAMLR, 2008; Jones et al., 2016). Although some of these fisheries were large and intensive, historical fishing locations were never made public and thus, recovery assessments of affected benthic habitats are unfortunately impossible.

Established and exploratory toothfish fisheries remain a source of concern regarding their impact to benthic communities. In the first comprehensive study of the effects of demersal gears on benthic habitats in the Southern Ocean, Welsford et al. (2014) found that longlines can affect benthic habitats as well as trawls. They found a key factor in managing these effects was to measure the overlap between demersal fishing activities and benthic habitats and then to estimate the effects on the productiveness and ecologies of those habitats given that interaction. A major part of achieving this is to use cameras deployed on fishing gear to observe those interactions directly and to help quantify the distribution of habitats (Welsford et al., 2014).

The magnitude of potential demersal fishing interactions with benthic habitats was determined for MEASO areas using catch and effort data from the CCAMLR Statistical Bulletin 2019 (see Grant et al., in review, to be published in this research topic, for more details than included here). These data were allocated to MEASO areas according to evidence for fishing depths and locations in reports of the Scientific Committee, CCAMLR Conservation Measures and descriptions in the scientific literature, in particular Kock (1992), on the fishing operations. Available fishing areas in the depth ranges of the fisheries were used to spread the catch uniformly across the identified reporting area of operation. Seabed areas were calculated from the GEBCO 2014 grid at $4 \mathrm{~km}^{2}$ resolution ${ }^{1}$. Catches were spread uniformly across the area identified from those sources for an individual catch based on flag state, depth range for a given target fishery and gear type and where reports allowed it, year. Figure 7 shows the total effort in both trawl (hours) and longline (hooks) in the CCAMLR area along with time-series of that effort in the MEASO assessment areas. The time series of catches of target species (groundfish, icefish and toothfish combined) are also shown to indicate the proportion of catch for which effort data were available.

\footnotetext{
${ }^{1}$ https://www.gebco.net/news_and_media/gebco_2014_grid.html
} 


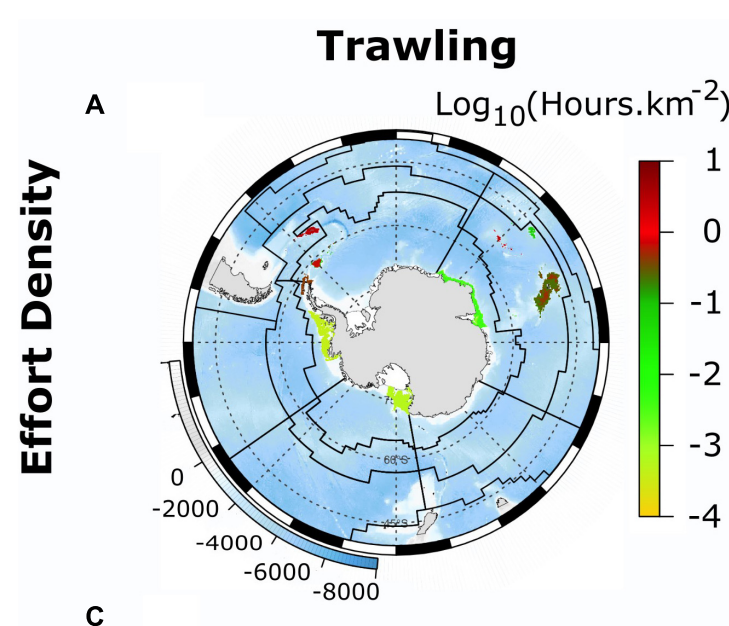

\section{Trawling}
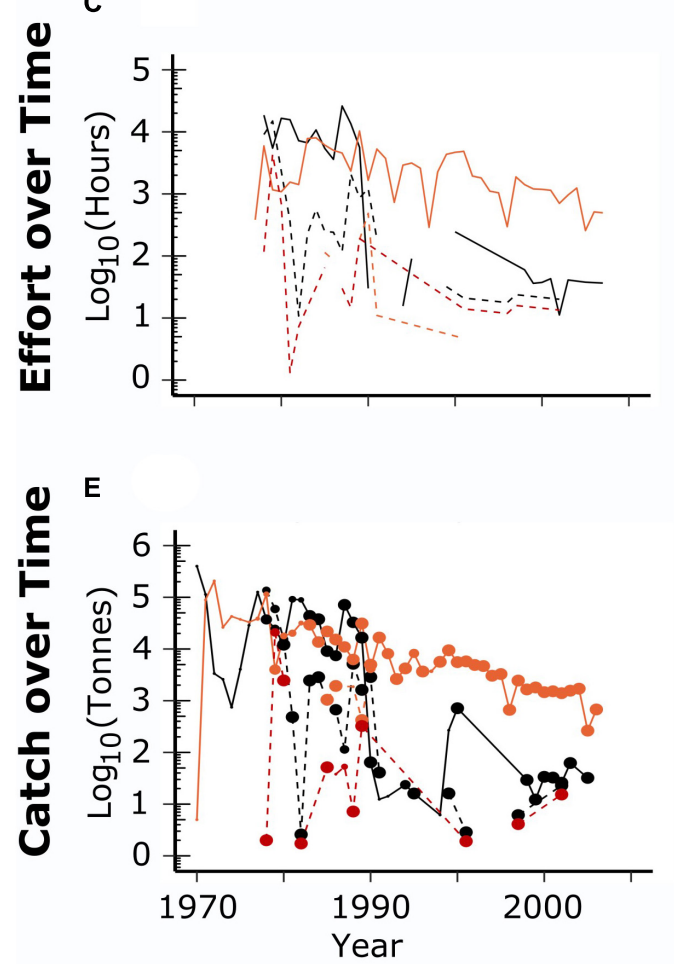

\section{Longlining}

B

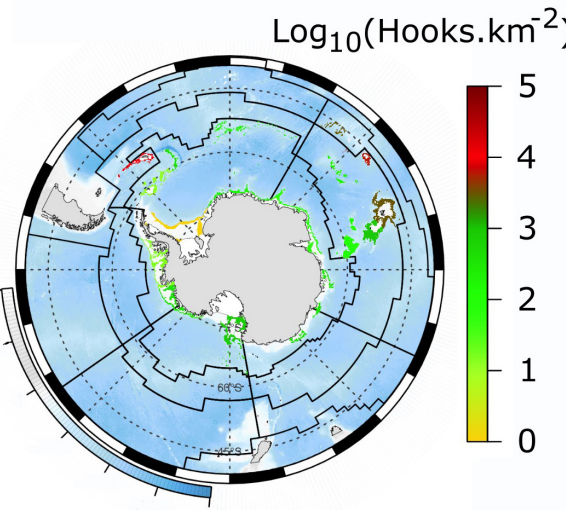

D
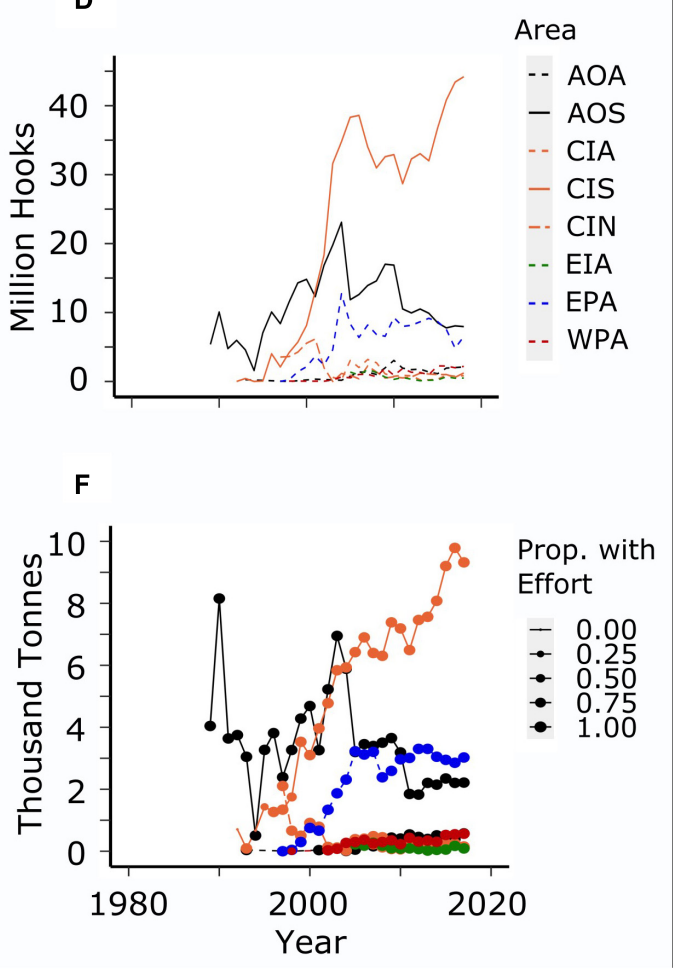

FIGURE 7 | Bottom fishing effort in MEASO areas for trawl and longline fisheries. (A,B) shows effort density per $\mathrm{km}^{2}$ - hours and hooks respectively on a log ${ }^{10}$ scale. Background is ocean depth (bottom left legend on each map). Black lines show boundaries of MEASO areas as depicted in Figures $\mathbf{3}$ and $\mathbf{4}$. (C,D) shows effort over time (split year) in each MEASO area according to the legend at right. The first two letters correspond to the sector and the last letter to the zone. (E,F) shows the time series of catches in each area - color and line types according to the middle row. Catches are the total catch of targeted species in bottom fisheries (groundfish, icefish, and toothfish). The size of the points indicate the proportion of the catch that had effort data associated with it. Note the effort and catch data are plotted on different scales for each of trawling and long lining and the size of the symbol for each year indicates the proportion of catch for which we have an estimate of effort. When there is no symbol in a year then there is no record of effort. Data derived from the CCAMLR Statistical Bulletin 2019 (see Grant et al., in review, to be published in this research topic).

Until CCAMLR established limits to catches of target species, the annual catches in some areas were two orders of magnitude greater than what is now considered sustainable (Caccavo et al., to be published in this research topic). Highest catches have been in the subantarctic zone of the Atlantic and Central Indian sectors during the 1970s and 1980s, ending in the early 1990s. Effort was not reported for the very high catches in the first two decades making it difficult to estimate the total past interaction with the seafloor.

Scaling the effort to the level of disturbance of the seafloor, also known as the fishing footprint, is best done using haul data, including the location of each haul. For trawls this normally includes the swept area of the net (width of the opening of the net combined with the distance towed), and for longlines the 
swept area of the line (sideways movement of the line during its deployment, fishing and retrieval). Haul data means that the footprint can be discounted by overlaps of each haul (see Welsford et al., 2014 for methods). In the absence of those data, we examine the effort density per $\mathrm{km}^{2}$ and use information from Welsford et al. (2014) to consider the proportion of seabed that might have been affected. The densities in Figure 7 may be lower than is experienced in local areas as a result of evenly distributing the available effort throughout the depth range of a fishery in an area. In addition, localized concentrations may also reduce the effects from repeated disturbance of the same area.

Effort densities in both trawl and longline were highest in the MEASO subantarctic zone in both the Atlantic and Central Indian sectors. Trawling also had high effort densities in the Antarctic zone of the East Pacific and Atlantic sectors, from trawling prior to CCAMLR around the Antarctic Peninsula and the islands of the Scotia Sea. Longline effort in the Antarctic zone has been greatest in the West Pacific sector associated with the Ross Sea fishery.

The greatest accumulated recorded effort for trawling has been a density of $3.1 \mathrm{~h}$ per $\mathrm{km}^{2}\left(\log _{10}=0.491\right.$; noting the absence of records for the very large catches). For longlining, the greatest accumulated density has been 11,000 hooks per $\mathrm{km}^{2}\left(\log _{10}=4.04\right)$. Using the mean estimates of swept areas for trawl gear $(20 \mathrm{~m})$ and longlines $(6.2 \mathrm{~m} \times 1 \mathrm{~m}$ per hook) from Welsford et al. (2014) and assuming trawling covered a conservative distance of 2 nautical miles per hour ( 2 knots), this equates to the proportion of area affected in these locations as $23 \%$ and $6.8 \%$ respectively.

A shortcoming of the current analysis is the lack of availability of geolocated haul data. Nevertheless, our analyses indicate that the magnitude of impact is unlikely to be trivial at a local scale, if the fisheries are concentrating in particular areas.

Marine Protected Areas (MPAs) can help offset local scale impacts on benthic habitats (Constable and Welsford, 2011; Welsford et al., 2014). To demonstrate that this may be the case, an assessment of the distribution of habitats inside and outside MPAs is needed (see Welsford et al., 2014). At present, CCAMLR has a process for identifying areas of important habitats (known as "Vulnerable Marine Ecosystems" or VMEs) based on the recovery of habitat-forming taxa during longline fishing. It has also declared some areas to be VMEs based on research data. While it now has several potential VMEs identified from fishing, there remains to be a follow-up evaluation of the nature and extent of those sensitive areas, which may be larger than the circumscribed locations.

\section{Prognoses}

The current extent of bottom trawling is restricted to areas for which there has been an assessment of how to manage bottom fisheries, while conserving benthic habitats (Welsford et al., 2014). MPAs have been shown to be an effective tool for achieving conservation while uncertainty remains regarding the environmental effects of fishing on benthos (Constable and Welsford, 2011; Welsford et al., 2014). Although CCAMLR has established two marine protected areas to date, the South Orkney Islands Southern Shelf MPA $\left(93,751 \mathrm{~km}^{2}\right.$ all no take) and Ross Sea Region MPA (1.53 million $\mathrm{km}^{2}$ open sea, 1.09 million $\mathrm{km}^{2}$ of which are no take) (Brooks et al., 2020), these do not provide coverage of the different benthic biomes to ensure comprehensive conservation of benthos in the Southern Ocean (Douglass et al., 2014a,b).

Three additional MPA proposals, in the Antarctic Peninsula $\left(466,000 \mathrm{~km}^{2}\right.$ proposed), East Antarctica $\left(969,000 \mathrm{~km}^{2}\right.$ proposed), and Weddell Sea (1.97 million $\mathrm{km}^{2}$ proposed) regions, are currently under consideration but are yet to be designated by CCAMLR as of 2020 (Brooks et al., 2020; CCAMLR, 2020). Whilst MPA proposals are in consideration, meaningful gains and essential improvements can still be made on policies that directly affect vulnerable benthic communities. For example, CCAMLR's list of VME indicator taxa is a "living document" (CCAMLR, 2009b) and requires updating (Box 1) to align its taxonomy with the World Register of Marine Species $^{2}$. Following the requirements of the 2007 United Nations General Assembly Sustainable Fisheries Resolution (61/105) (UNGA, 2007), aimed at avoiding significant adverse impacts of bottom fishing activities on VMEs in high seas areas, CCAMLR implemented procedures to identify and protect these communities and habitats via adoption of several Conservation Measures (Jones et al., 2016; Table 2). CCAMLR has interpreted a VME to be consistent with a community that includes the presence of benthic invertebrates that significantly contribute to the creation of complex three-dimensional structure, cluster in high densities, change the structure of the substratum, provide substrata for other organisms or are rare or unique (CCAMLR, 2009b). Considering traits such as rarity, slow growth, fragility and lack of larval dispersal, CCAMLR produced a list of 27 taxa that when present in high or rare abundances indicate the presence of a VME (CCAMLR, 2009c).

The threshold for VMEs (see Table 2) currently in place for use by fisheries in the Southern Ocean is biased toward spongedominated communities, as the threshold is mass dependent and all indicator taxa are pooled and treated equally. Diverse coral communities may fail to trigger thresholds based on densities of all indicator taxa pooled (Lockhart and Hocevar, accepted), and without the availability of direct imagery, a diverse range of coral communities and vast calcareous bryozoan reefs would not be included in CCAMLR's VME registry (Jones and Lockhart, 2011). Protecting a variety of VMEs is crucial, as coral communities are not only among the most vulnerable due to their fragility, great longevity and slow growth (Roark et al., 2005; Rogers et al., 2008; Maynou and Cartes, 2012; Peck and Brockington, 2013; Martinez-Dios et al., 2016), but also because of the potential carbon storage of cold-water coral communities of the Southern Ocean, as previously discussed (Barnes, 2017b; Barnes et al., 2018).

\section{Tourism \\ Responses}

The number of tourists visiting the Antarctic has increased dramatically since the 1980s (Yves, 2019), the 2018-2019 season saw an $8 \%$ increase on the previous year with a total of 56,186

${ }^{2}$ http://marinespecies.org/ 
TABLE 2 | Vulnerable Marine Ecosystem (VME) encounter protocols within the CCAMLR area including evidence required and potential protection (CCAMLR, 2019a).

\begin{tabular}{|c|c|c|c|}
\hline Notification by & Evidence & Protection & $\begin{array}{c}\text { CCAMLR } \\
\text { conservation } \\
\text { measures }\end{array}$ \\
\hline $\begin{array}{l}\text { Fishery-independent } \\
\text { research }\end{array}$ & $\begin{array}{l}\text { Scientific report or proposal for VME Variety of evidence } \\
\text { acceptable }\end{array}$ & $\begin{array}{l}\text { If granted by consensus, protection from all bottom } \\
\text { fishing to one nautical mile radius of VME encounter }\end{array}$ & CM 22-06 \\
\hline Fishery & $\begin{array}{l}\text { Benthic bycatch exceeds } 10 \mathrm{~kg} \text { of indicator taxa per } \\
1200 \mathrm{~m} \text { section of long or pot line (higher threshold) }\end{array}$ & VME Risk Area Move-on rule & $\mathrm{CM} 22-07$ \\
\hline Fishery & $\begin{array}{l}\text { Benthic bycatch exceeds } 1 \mathrm{~kg} \text { of indicator taxa per } 1200 \mathrm{~m} \\
\text { section of longline (lower threshold) }\end{array}$ & Fishing vessel notification of potential VMEs & CM 22-07 \\
\hline
\end{tabular}

tourists (IAATO, 2019a). Most of this tourism is concentrated along the West Antarctic Peninsula and subantarctic regions in the West Pacific sector of Antarctica and the Atlantic and Central Indian subantarctic MEASO sectors respectively (Lynch et al., 2010; Bender et al., 2016). Whilst tourism impact assessments exist (e.g., Kriwoken and Rootes, 2000; ASOC, 2008) they tend to overlook direct impacts on benthic habitats. Tourist activities that could directly impact the benthos include small boat landings, kayaking, scuba diving, snorkeling, submersibles, remotely operated vehicles and anchoring. More specifically, landings in ice-free intertidal habitats may trample sessile species, paddles from kayaks, scuba divers and snorkelers may disturb or damage fragile species such as corals and sponges, whilst submersibles and anchoring may have the most destructive impacts if landing on or scraping the seafloor.

The International Association of Antarctica Tour Operators (IAATO) provide field operation manuals and guidelines for tourist specific activities (see IAATO, 2019b for full list). Guidelines for small boat practices, including kayaking, mostly advise on operations in the vicinity of ice and anchoring is not advised in certain areas due to poor ground holding rather than the presence of vulnerable benthic habitats (IAATO, 2012). Prerequisites for underwater activities (including diving and snorkeling) include staffing by an experienced dive master in polar waters who should advise on "wildlife awareness" during the dive briefing and all diving is limited to a depth of $20 \mathrm{~m}$. Guidelines for submersibles and remotely operated vehicles specifically mention seafloor communities, stating that "when setting down on the seafloor, care should be taken to avoid areas with high concentrations of marine life, especially soft invertebrates while sitting on or hovering close to the bottom, use thrusters minimally to avoid disturbing the delicate benthic community." IAATO has also provided environmental recommendations for new activities, highlighting that those with the potential to have "more than a minor or transitory impact" should be altered or stopped.

\section{Prognoses}

There is not enough data regarding the direct benthic impacts of tourism for a full assessment of this driver. The current level of potential impact may be "low," however if the majority of this activity is repeatedly concentrated en masse the potential for local detrimental impacts increases (Bender et al., 2016).
The potential impact of these activities grows with an evolving tourist industry; for example, the increasing number of larger vessels (over 200 passengers) for which there are fewer potential landing sites (Bender et al., 2016) could increase impacts on landing sites and at the deeper anchorages that they are limited to. At present the use of submersibles in Antarctic tourism is relatively low, only operated by two IAATO registered vessels in the 2019/2020 season (IAATO pers. comms.). This number is expected to increase, with corresponding increase in the potential damage to fragile benthic species and habitats unless operational guidelines are updated with stricter protocols.

Although nearly all Antarctic tourism operators are members of IAATO, those that are not members can and do travel to the Antarctic, and potentially lack awareness of, or regard for, IAATO vessel code of conduct. IAATO vessel code of conduct promotes environmental protection based on IAATO and Antarctic Treaty Consultative Meeting guidelines and, where appropriate, adheres to all national and international legal requirements including the International Convention for the Prevention of Pollution from Ships (MARPOL). However, whilst there has been an increasing trend in Antarctic tourism, the future of the industry post the COVID-19 outbreak is unclear.

\section{Plastics \\ Responses}

To date, microplastics have been found in sediments in the Ross Sea (Munari et al., 2017), Admiralty Bay (South Shetland Islands) (Absher et al., 2019), near Rothera Station (Reed et al., 2018), in the vicinity of South Georgia (Barnes et al., 2009), and the deep Weddell Sea (Van Cauwenberghe et al., 2013), at similar concentrations to microplastics within sediments in shallow and deep-sea samples outside of the Antarctic region. Whilst we do not have any records of microplastic ingestion in Southern Ocean benthic species, there are records from outside the Southern Ocean and experiments showing that microplastics are ingested across most benthic functional groups (including suspension, deposit, predatory feeders) (e.g., Wright et al., 2013; Van Cauwenberghe et al., 2015; Taylor et al., 2016). Within the vicinity of research stations, including Rothera (West Antarctic Peninsula) and Mario Zucchelli Station (Ross Sea), microplastics concentrations in sediments decrease with distance from the base (Munari et al., 2017; Reed et al., 2018). The current concentrations may be negligible on the Southern Ocean 
scale, but high at local scales if concentrated at point sources (Waller et al., 2017a). However, we do not fully understand how microplastics are transported within the Southern Ocean. For more details regarding transport of plastics in the Southern Ocean via the atmosphere, cryosphere and ocean currents please see Morley et al. (2020) in this research topic.

\section{Prognoses}

Benthic habitats, including the deep sea, have become a final resting place for marine debris including microplastics (Woodall et al., 2014; Taylor et al., 2016). Thus, surface marine plastic such as the 1,794 items $\mathrm{km}^{-2}$ in the surface water at the Antarctica Peninsula (Lacerda et al., 2019) demonstrates the risk of increasing plastic contamination to benthic habitats in the future. At an individual level, we know that benthic organisms can ingest microplastics, for example non-selective deposit feeders have been observed to have a higher load of microplastics than other benthic feeders and therefore may exhibit the highest risk (Waller et al., 2017a). Such ingestion can have a negative impact on individual survival, however at present we do not know the risk to benthic food webs and communities, or the role of microplastics in larger-scale ecosystem changes (Browne et al., 2015). Outside of the Southern Ocean, potential microplastic pathways in benthic food webs have been observed, including the transfer from seagrasses to herbivores around the Turneffe Atoll, and microplastics appear to bioaccumulate within predatory sea stars in the Arctic (Fang et al., 2018; Goss et al., 2018). However, the transfer of microplastics through marine food webs and potential for biomagnification is not fully understood and is a key topic for global marine research (Provencher et al., 2018). Within the Southern Ocean, the habitats most vulnerable to microplastic pollution are likely to be near research stations and areas of increased greywater entering the ocean. However, the transport of microplastics and accumulation patterns needs to be better understood (Waller et al., 2017a; Reed et al., 2018). From a benthic perspective, future research should focus on the sources of microplastics, the mechanisms for transport and process of accumulation as well as the ecological effects of microplastics within the food web. In addition, given the clear link between fisheries discard and marine debris, enforcement of global fisheries to limit plastic waste is a research and policy priority (Walker et al., 1997; Sheavly and Register, 2007). These research areas reflect the key questions proposed by the "Plastics in Polar Environments" group of Scientific Committee on Antarctic Research (SCAR) ${ }^{3}$.

\section{Pollution}

\section{Responses}

The environmental impacts of sewage and wastewater on benthic communities have been studied at McMurdo (Lenihan et al., 1990; Conlan et al., 2004; Kim et al., 2019), Rothera (Hughes and Thompson, 2004), Casey (Stark et al., 2003, 2014; Stark, 2008), and Davis stations (Stark et al., 2015, 2016). The most comprehensive study to date at Davis station found multiple lines of evidence of environmental impacts within local benthic

${ }^{3}$ https://www.scar.org/science/plastic/home/ habitats (Stark et al., 2016). This included: histopathological abnormalities in fish (Corbett et al., 2014), isotopic enrichment in fish and predatory invertebrates (Stark et al., 2016), Escherichia coli carrying antibiotic resistance determinants found in the local water, sediments and filter feeding invertebrates (Power et al., 2016) and community differences between control and outfall sites. Changes in benthic communities have also been detected around outfalls at McMurdo and Casey stations (Conlan et al., 2004; Stark et al., 2016) and dispersal of sewage has been studied around Rothera station (Hughes and Nobbs, 2004; Hughes and Thompson, 2004).

Former waste disposal sites on shorelines around coastal research stations, combined with meltwater runoff through such sites, has also resulted in pollution of marine sediments by metals, persistent organic pollutants and hydrocarbons, leading to localized changes in macrofaunal communities (Lenihan and Oliver, 1995; Stark et al., 2005, 2014), uptake of contaminants by biota and reduced biodiversity (Duquesne and Riddle, 2002; Stark et al., 2004). At a species level there is relatively limited knowledge on the sensitivity and bioaccumulation of pollutants on benthic species (Lister et al., 2015; Alexander et al., 2017; Brown et al., 2017). Heavy-metal studies have shown demonstrated variability within phyla and further research is required before water quality guidelines for the Southern Ocean can be established (Kefford et al., 2019; Webb et al., 2019).

\section{Prognoses}

The current minimum wastewater treatment and disposal requirements under the Protocol on Environmental Protection to the Antarctic Treaty (simple maceration where populations exceed 30 in summer) are insufficient to prevent adverse effects to benthic ecosystems (Stark et al., 2016), yet are widely practised by most nations operating in Antarctica. With the projected increase in the number of vessels and research stations in Antarctica the installation of modernized wastewater treatment systems are required to mitigate the negative impacts to benthic communities described in Stark et al. (2016). At present, an advanced treatment system has been installed at Davis station, which consists of two separate processes. First, an advanced membrane filtration technology which reduces the concentration of most contaminants and second, a purification system which treats water to produce high quality potable water, suitable for reuse. Such systems have the additional benefit of reducing power (and thus $\mathrm{CO}_{2}$ emissions) required to melt ice for water use and increase the availability of water on stations where there are limited local resources. However, there is a reluctance or failure to adopt such technologies by national Antarctic operators, despite their proven effectiveness in remote communities. The last available survey showed that $37 \%$ of permanent stations and $69 \%$ of summer stations lack any form of treatment facility (Gröndahl et al., 2009).

Hydrocarbons represent one of the main pollution risks to coastal Antarctica. Stations are the main source of oils and fuel to the marine environment and pose a significant risk, especially where situated in catchment areas that drain to the sea. Other sources of hydrocarbons include abandoned stations and fuel depots, wastewater outfalls, former waste disposal 
sites and vehicle wrecks (Raymond et al., 2017). Hydrocarbons spilled in Antarctic marine environments have been shown to persist in sediments for long periods and undergo very slow degradation (Thompson et al., 2006; Powell et al., 2010), causing effects in marine benthic communities (Lenihan and Oliver, 1995; Powell et al., 2010; Polmear et al., 2015; Stark et al., 2017), which are likely to persist for decades. Shipping activity poses the greatest risk of fuel and oil spills. The challenges of responding to fuel and oils spills in the Antarctic have been recognized, and have led to the requirement under the Madrid Protocol (Antarctic-Environmental Protocol, 1991) for all Parties to have contingency plans for prompt and effective response to environmental emergencies. The adoption of the Polar Code for shipping also includes a ban on the use and carriage of heavy fuel oil in the Antarctic region.

\section{Non-indigenous Species Responses}

The introduction, establishment, and impact of non-indigenous species in the Antarctic region is receiving growing attention from researchers and stakeholders. Small coastal parts of the Southern Ocean, mainly the shallows around some research stations and tourist hotspots are regularly monitored for community change, especially where there are frequent SCUBAdiving operations, such as at Arctowski, Carlini, Palmer, and Rothera research stations on the South Shetland Islands and West Antarctic Peninsula. Monitoring of such areas as well as tourism hotspots, e.g., Deception Island, has detected a few non-indigenous algae and the invasive bryozoan species Membranipora membranacea (Linnaeus, 1767; Avila et al., 2020). Live mytilid mussels have been recorded entering the Southern Ocean on ship hulls (Lee and Chown, 2007), and a single specimen was found in the shallows at Grytviken, South Georgia (Ralph et al., 1976) with more recent settlement and successful reproduction within the South Shetlands (Cárdenas et al., 2020). There are also established populations of the polychaete worm Chaetopterus variopedatus (Renier, 1804) at these shipping hotspots in the shallows around South Georgia (Hughes et al., 2020). To date it is thought that there are few if any marine non-indigenous species established on Antarctic coasts, albeit detection might be unlikely unless it was from a taxon otherwise unrepresented. However, as the polar front retreats southwards under climate forcing (Meijers et al., 2012), Antarctic species established on the current northern margins (for example on the Kerguelen Plateau) will naturally "invade" southwards - their persistence and performance could be strong indicators for how species further south will cope with predicted physical change. Modeling has shown Southern Ocean environments are currently suitable for potentially invasive benthic species such as Asterias amurensis Lutken, 1871 and that changes in important variables (sea surface temperature, salinity, $\mathrm{pH}$ and nitrate) could mean up to 13 other hull-fouling benthic species also pose an invasion risk under climate change scenarios (Holland et al., in press). For more information about the introduction and establishment nonindigenous species within the Southern Ocean and the regulatory frameworks and existing measures to limit drivers or mitigate their impacts see Grant et al. (in review), to be published in this research topic.

\section{Prognoses}

The combination of increased propagule pressure (the number of individuals of a species introduced to an area to which they are not native) (Hughes et al., 2020), increase of anthropogenic vector density (e.g., ships and plastics), sea ice losses, near surface warming and other physical changes make arrival and establishment of non-indigenous species around Antarctic coasts much more likely. Predicting which non-indigenous species are threats, which indigenous species are most vulnerable, and which vectors and locations are most likely to be involved is a difficult task, but there are obvious "usual suspects" (Hughes et al., 2020). Broadly, areas of focus for non-indigenous introductions will be north West Antarctic Peninsula and South Georgia, in hotspots of tourist ship visits, and monitoring is likely to continue within $1 \mathrm{~km}$ of active marine research stations (which are coincidentally also hotspots of sea ice loss and warming). However, these same parts of West Antarctica, more specifically the northern tip of the Antarctic Peninsula, South Shetland and South Georgia Islands, also have higher non-indigenous species establishment and spread risks due to stronger past, present and predicted climate change (for example reducing sea ice and warming surface waters). Nine marine species have been identified as high risk invasive non-native species that are most likely to threaten the biodiversity and ecosystems of the Antarctic Peninsula region, including three species of bivalves, two ascidians, one polychaete worm, two crabs and one type of algae (Hughes et al., 2020).

The impact of non-indigenous species is difficult to predict; whilst it could lead to reduced diversity and functional homogenization of benthic communities, it is somewhat dependent on the other interacting impact drivers (Aronson et al., 2015; Morley et al., 2019). Other than a requirement to exchange ballast water away from the continental shelf when entering the Southern Ocean, marine biosecurity measures are still in their infancy, despite the near impossible task of removing marine aliens after detection. There is widespread knowledge that hull cleaning of vessels prior to entry into the Southern Ocean could greatly reduce risks of non-indigenous transport (Lee and Chown, 2009; Hughes et al., 2020). However, this is an expensive and time-consuming step for IAATO and tourism operators. In addition, the risks of non-indigenous species on the marine environment and the impacts of anti-fouling treatments to non-target (Antarctic) species (e.g., Lewis et al., 2004) need to be considered.

\section{CUMULATIVE IMPACTS OF MULTIPLE DRIVERS}

In the previous sections impact drivers have been discussed mostly in isolation but in reality, benthic communities will experience multiple drivers of change simultaneously. Controlled laboratory experiments have considered the 
synergistic impacts of temperature, ocean acidification and pollution on individual benthic species (e.g., Ericson et al., 2012; Benedetti et al., 2016; Foo et al., 2016). There have also been in situ experiments such as Lenihan et al. (2018) which investigated the colonization of soft-sediments exposed to multiple chemical contaminants, altered organic carbon content and predator disturbance. Significant shifts in community structure, and potential functionality, have been predicted in shallower, flatter hard substratum, which with decreased sea ice duration are likely to receive the most light and increased sedimentation (Clark et al., 2017). For other shelf habitats the greatest disturbance is most likely to be from the combined impacts of iceberg disturbance and ocean acidification (Gutt et al., 2015). Figure 8 indicates where multiple drivers could impact specific functional groups already exposed to changing ocean conditions.

When it comes to projecting changes in benthic biodiversity and ecosystem functioning, uncertainties arise from the nonlinear nature of most ecological processes, spatial differences, feedbacks and synergistic effects of multiple stressors (Gutt et al., 2015). A comprehensive quantification of such processes is still impossible due to incomplete representative datasets of physicalchemical drivers over space and time. A better quantification of ecosystem functions by state-of-the-art interdisciplinary ecological models, which include biological factors such as species-specific potentials for adaptation and acclimation (Gutt et al., 2012, 2018; Kennicutt et al., 2014) are needed to develop scenarios of Southern Ocean ecological processes in the future. The liaison between disciplines is crucial to making data collection at comparable and meaningful scales to help determine holistic biota responses to ecosystem change and inform modeling analyses (see next section). Devising strong sentinel locations, taxa (or functional groups) and important, standardized performance measures will likewise help assess biological response to environmental changes.

\section{SUMMARY FOR POLICYMAKERS}

Southern Ocean benthic ecosystems are responding to climate impacts in complex and often unpredictable ways. Isolated for millennia, benthic species have evolved to meet unique environmental challenges of life on the Southern Ocean seafloor. Climate change is poised to disrupt this habitat, altering the processes, assemblages, population dynamics, and ultimately survival rates of seafloor species. The difficulty in assessing the overall impact of climate change on benthic species is due to the challenges inherent to conducting research in the Southern Ocean, regional differences in the number and level of impact drivers, the cumulative impacts of predicted changes, and the non-linearity of multiple stressors on biodiverse benthic communities. Despite this, there are clear governance structures

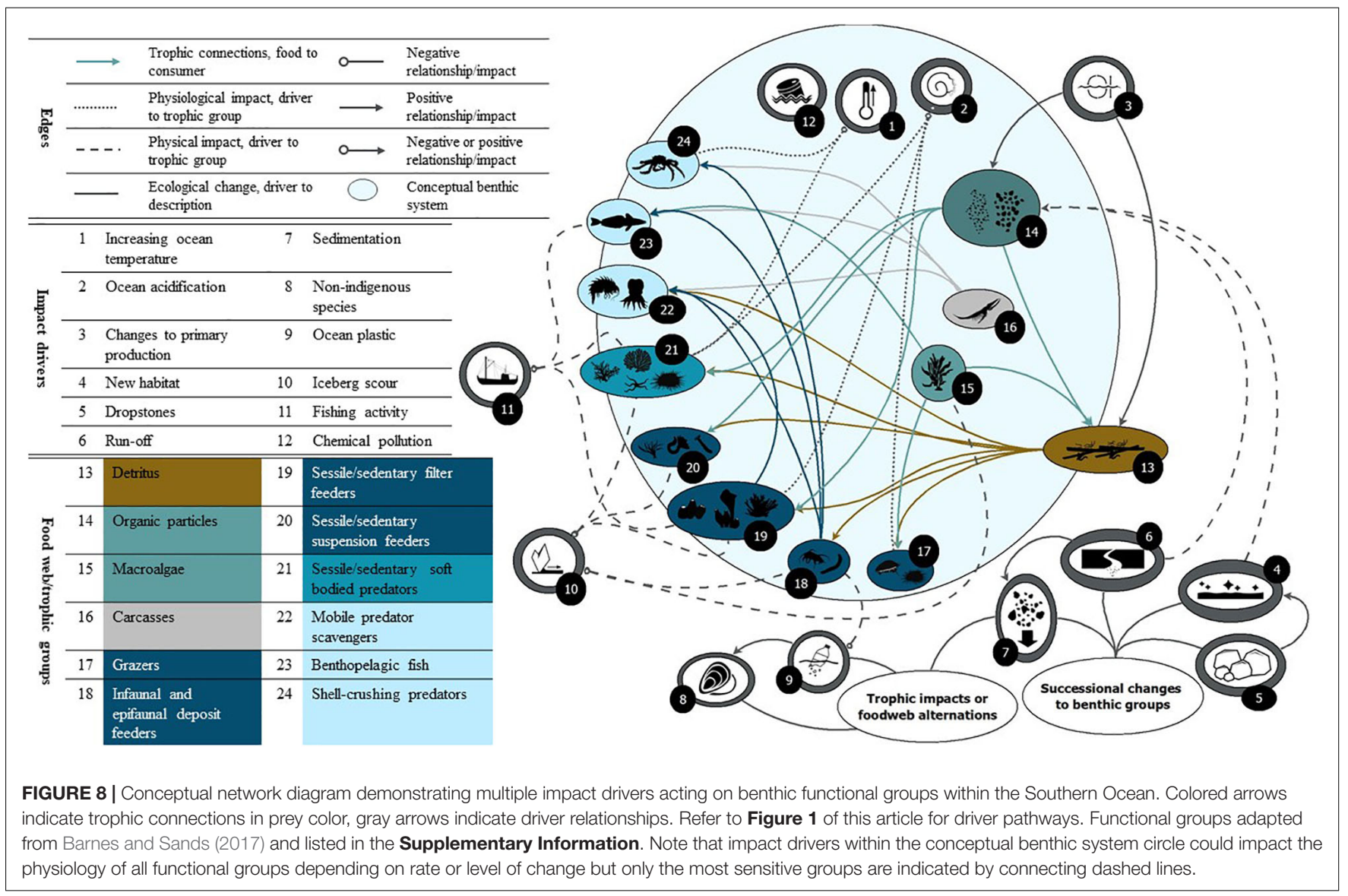


that policymakers can explore and implement to minimize the impact of climate change on benthic invertebrate ecosystems.

Governing bodies have thus far been slow to respond to the effects of climate change on Southern Ocean ecosystems, despite the urgency. Policy areas most deficient and in need of immediate attention and improvement for Southern Ocean benthos conservation include:

- International effort is needed to enforce a reduction in fishing debris and plastic waste entering the ocean that ultimately resides on the sea floor.

- A network of MPAs, including appropriate fishing restrictions, is urgently required in the Southern Ocean to help ecosystems deliver important services and allow for species to adapt to changing conditions.

- CCAMLR's VME protocols require updating, removing taxonomic bias in the implementation of thresholds, particularly for the protection of species with greater carbon-storage potential.

- Stricter protocols are needed for research and tourist vessels entering the Antarctic, to reduce the direct and indirect impacts of human activities. These include revised guidelines for the use of submarines and for direct contact by landings to benthic habitats, the introduction of marine plastics and other pollutants and the transport of nonindigenous species that could have major impacts on the diversity and functioning of benthic communities.

- Modernizing the environmental guidelines of the Committee for Environmental Protection (CEP) of the Antarctic Treaty to reflect up-to date knowledge of the status and nature of the risks of environmental change on Antarctic marine benthic ecosystems.

These actions, as well as a better understanding of benthic ecosystem dynamics (Box 1), can help lead to long-term management that adequately accounts for climate change impacts on Southern Ocean benthos.

\section{AUTHOR CONTRIBUTIONS}

MB, DB, SM, CW, JG, ABC, HG, and AV attended the MEASO2019 workshop in Woking (UK) where this manuscript was outlined. MB coordinated and compiled text contributions from co-authors, wrote the introductory and concluding sections, constructed Figures 1, 5 and 8, and finalised the manuscript. HS reviewed and analysed the data available for Figure 4. AP and MS produced Figure 3. SM and HG provided content for the ocean temperature section. DB, JS, AP, and JG provided content for the ice shelf disintegration, increased iceberg scour and biogenic flux section. DB and AP provided content for the glacial retreat, sedimentation, and newly ice-free habitats section. JS, AP, DB, JG, and SM provided content for the sea ice change, light, and primary production. $\mathrm{NB}, \mathrm{BF}$, and $\mathrm{RD}$ provided content for the ocean acidification section. SL, ABC, NB, and $\mathrm{MB}$ provided content for the fishing section and summary for policymakers.
JS and RD provided content for the pollution section. $\mathrm{MB}, \mathrm{CW}$, and $\mathrm{HG}$ provided content for the plastics section. JS, DB, and $\mathrm{MB}$ provided content for the non-indigenous species section. $A B$ provided a deep-sea perspective throughout the manuscript providing content where relevant, JS did the same for shallow water. AJC advised on all sections, contributed to the fishing section including data analysis for Figure 7. All co-authors were invited to review and edit content prior to manuscript submission and during review.

\section{FUNDING}

MB was supported by the Antarctic Climate \& Ecosystems Cooperative Research Centre and PEW Charitable Trusts. RD was funded by an Australian Government Research Training Program (AGRTP). SM and HG were funded through NERC core funding to the British Antarctic Survey Biodiversity, Evolution and Adaptation Team. BF was supported by a postdoctoral contract Juan de la Cierva-Incorporación (IJCI-2017-31478) of Ministerio de Ciencia, Innovación y Universidades. AV was funded by the Belgian Science Policy Office (BELSPO, contract $\left.\mathrm{n}^{\circ} \mathrm{FR} / 36 / \mathrm{AN} 1 / \mathrm{AntaBIS}\right)$ in the Framework of EU-Lifewatch.

\section{ACKNOWLEDGMENTS}

This work is a core contribution to the first Marine Ecosystem Assessment for the Southern Ocean (MEASO) of IMBeR's program ICED. We thank those who contributed to our benthic laboratories survey including Juan Hofer, Piotr Kuklinski, Doris Abele, Ricardo Sahade, César Cárdenas, and Mercedes Santos (on behalf of Ant-ICON). Jan Jansen for their comments regarding the future studies section of this manuscript. The stakeholders who provided feedback during the MEASO consultation process including: SOOS, PEW, WWF, CEP and SC-CAMLR. Stacey McCormack from Visual Knowledge for turning Figures 2 and 6 into infographics. We thank the MEASO Support Group and Steering Committee for assisting with figures, coordination and editing of the text. Additional thanks are due to WWF, PEW and COLTO who supported the MEASO project and MB whilst writing this manuscript. AP publishes with the permission of the Chief Executive Officer, Geoscience Australia. BF received institutional support of the 'Severo Ochoa Centre of Excellence' accreditation (CEX2019-000928-S). We thank our two reviewers for their constructive comments and suggestions during the review process. We are grateful for support to publish this paper from The Pew Charitable Trusts.

\section{SUPPLEMENTARY MATERIAL}

The Supplementary Material for this article can be found online at: https://www.frontiersin.org/articles/10.3389/fmars. 2021.622721/full\#supplementary-material 


\section{REFERENCES}

Absher, T. M., Ferreira, S. L., Kern, Y., Ferreira, A. L., Christo, S. W., and Ando, R. A. (2019). Incidence and identification of microfibers in ocean waters in Admiralty Bay. Antarctica. Environ. Sci. Pollut. Res. 26, 292-298. doi: 10.1007/ s11356-018-3509-6

Alexander, F. J., King, C. K., Reichelt-Brushett, A. J., and Harrison, P. L. (2017). Fuel oil and dispersant toxicity to the Antarctic sea urchin (Sterechinus neumayeri). Environ. Toxicol. Chem. 36, 1563-1571. doi: 10.1016/j.aquatox. 2015.01.031

Allcock, A. L., Barratt, I., Eléaume, M., Linse, K., Norman, M. D., Smith, P. J., et al. (2011). Cryptic speciation and the circum polarity debate: a case study on endemic southern ocean octopuses using the COI barcode of life. Deep Sea Res. II. 58, 242-249. doi: 10.1016/j.dsr2.2010.05.016

Andersson, A. J., Mackenzie, F. T., and Gattuso, J.-P. (2011). "Effects of ocean acidification on benthic processes, organisms, and ecosystems," in Ocean Acidification, eds J. -P. Gattuso and L. Hansson (New York, NY: Oxford University Press), 122-153.

Antarctic-Environmental Protocol (1991). Protocol on Environmental Protection to the Antarctic Treaty. Madrid.: Antarctic-Environmental Protocol.

Arndt, J. E., Schenke, H. W., Jakobsson, M., Nitsche, F. O., Buys, G., Goleby, B., et al. (2013). The international bathymetric chart of the southern ocean (IBCSO) Version 1.0 - A new bathymetric compilation covering circumAntarctic waters. Geophys. Res. Lett. 40, 311-317. doi: 10.1002/grl.50413

Arntz, W. E., Gutt, J., and Klages, M. (1997). "Antarctic marine biodiversity: an overview," in Antarctic Communities: Species, Structure and Survival, eds B. Battaglia, J. Valencia, and D. W. H. Walton (Cambridge: Cambridge University Press), 3-14. doi: 10.7208/chicago/9780226904146.003.0001

Aronson, R. B., Frederich, M., Price, R., and Thatje, S. (2015). Prospects for the return of shell-crushing crabs to Antarctica. J. Biogeogr. 42, 1-7. doi: 10.1111/ jbi. 12414

Aronson, R. B., Thatje, S., Clarke, A., Peck, L. S., Blake, D. B., Wilga, C. D., et al. (2007). Climate change and invasibility of the Antarctic benthos. Annu. Rev. Ecol. Syst. 38, 129-154. doi: 10.1146/annurev.ecolsys.38.091206.095525

Arrigo, K. R., van Dijken, G. L., and Bushinsky, S. (2008). Primary production in the Southern Ocean, 1997-2006. J. Geophys. Res. Oceans 113:C08005. doi: 10.1029/2007JC004578

ASOC (2008). A Decade of Antarctic Tourism: Status, Change, and Actions Needed. Antarctic Treaty Consultative Meeting, Kiev, Ukraine. ATCM 11, CEP 6(b). New Delhi: ASOC.

Avila, C., Angulo-Preckler, C., Martín-Martín, R. P., Figuerola, B., Griffiths, H. J., and Waller, C. L. (2020). Invasive marine species discovered on non-native kelp rafts in the warmest Antarctic island. Sci. Rep. 10:1639. doi: 10.1038/s41598020-58561-y

Baggini, C., Issaris, Y., Salomidi, M., and Hall-Spencer, J. (2015). Herbivore diversity improves benthic community resilience to ocean acidification. J. Exp. Mar. Biol. Ecol. 469, 98-104. doi: 10.1016/j.jembe.2015.04.019

Baird, H. P., Miller, K. J., and Stark, J. S. (2011). Evidence of hidden biodiversity, ongoing speciation and diverse patterns of genetic structure in giant Antarctic amphipods. Mar. Ecol. 20, 3439-3454. doi: 10.1111/j.1365-294X.2011.05173.x

Barnes, D. K., Ashton, G. V., Morley, S. A. and Peck, L. S. (2021). $1^{\circ} \mathrm{C}$ warming increases spatial competition frequency and complexity in Antarctic marine macrofauna. Commun. Biol. 4, 208. doi: 10.1038/s42003-021-01742-w

Barnes, D. K., Fenton, M., and Cordingley, A. (2014). Climate-linked iceberg activity massively reduces spatial competition in Antarctic shallow waters. Curr. Biol. 24, 553-554. doi: 10.1016/j.cub.2014.04.040

Barnes, D. K., Galgani, F., Thompson, R. C., and Barlaz, M. (2009). Accumulation and fragmentation of plastic debris in global environments. Philos. Trans. $R$. Soc. Lond. B. Biol. Sci. 364, 1985-1998. doi: 10.1098/rstb.2008.0205

Barnes, D. K., Kuklinski, P., Jackson, J. A., Keel, G. W., Morley, S. A., and Winston, J. E. (2011). Scott's collections help reveal accelerating marine life growth in Antarctica. Curr. Biol. 21, 147-148. doi: 10.1016/j.cub.2011.01.033

Barnes, D. K., and Sands, C. J. (2017). Functional group diversity is key to Southern Ocean benthic carbon pathways. PloS One 12:e179735. doi: 10.1371/journal. pone.0179735

Barnes, D. K., Sands, C. J., Cook, A., Howard, F., Roman Gonzalez, A., MuñozRamirez, C., et al. (2020). Blue carbon gains from glacial retreat along Antarctic fjords: What should we expect? Glob. Change Biol. 26, 2750-2755. doi: 10.1111/ gcb.15055

Barnes, D. K., and Souster, T. (2011). Reduced survival of Antarctic benthos linked to climate-induced iceberg scouring. Nature Clim. Change 1, 365. doi: 10.1038/ nclimate 1232

Barnes, D. K. A. (2015). Antarctic sea ice losses drive gains in benthic carbon drawdown. Curr. Biol. 25, 789-790. doi: 10.1016/j.cub.2015.07.042

Barnes, D. K. A. (2017a). Polar zoobenthos blue carbon storage increases with sea ice losses, because across-shelf growth gains from longer algal blooms outweigh ice scour mortality in the shallows. Glob. Chang. Biol. 23, 5083-5091. doi: $10.1111 /$ gcb.13772

Barnes, D. K. A. (2017b). Iceberg killing fields limit huge potential for benthic blue carbon in Antarctic shallows. Glob. Chang. Biol. 23, 2649-2659. doi: 10.1111/ gcb. 13523

Barnes, D. K. A., Fleming, A., Sands, C. J., Quartino, M. L., and Deregibus, D. (2018). Icebergs, sea ice, blue carbon and Antarctic climate feedbacks. Phil. Trans. R. Soc. A. 376, 20170176. doi: 10.1098/rsta.2017.0176

Bax, N. (2014). Deep-Sea Stylasterid Corals in the Antarctic, Subantarctic and Patagonian Benthos: Biogeography, Phylogenetics, Connectivity and Conservation. Ph.D. thesis, University of Tasmania, Hobart.

Bax, N., Sands, C. J., Gogarty, B., Downey, R. V., Moreau, C. V., Moreno, B., et al. (2021). Perspective: increasing blue carbon around Antarctica is an ecosystem service of considerable societal and economic value worth protecting. Glob. Change Biol. 27, 5-12. doi: 10.1111/gcb.15392

Bax, N. N., and Cairns, S. D. (2014). "Stylasteridae (Cnidaria; Hydrozoa)," in Biogeographic Atlas of the Southern Ocean, eds C. de Broyer, P. K. Koubbi, H. J. Griffiths, B. Raymond, C. d'Udekem d'Acoz, A. Van de Putte, et al. (Cambridge: Scientific Committee on Antarctic Research), 107-212.

Beaman, R. J., and Harris, P. T. (2003). Seafloor morphology and acoustic facies of the George V Land shelf. Deep Sea Res. Part II Top. Stud. Oceanogr. 50, 1343-1355. doi: 10.1016/S0967-0645(03)00071-7

Beaman, R. J., and Harris, P. T. (2005). Bioregionalization of the George V Shelf, East Antarctica. Cont. Shelf Res. 25, 1657-1691. doi: 10.1016/j.csr.2005.04.013

Bender, N. A., Crosbie, K., and Lynch, H. J. (2016). Patterns of tourism in the Antarctic Peninsula region: a 20-year analysis. Antarct. Sci. 28, 194-203. doi: 10.1017/S0954102016000031

Benedetti, M., Lanzoni, I., Nardi, A., d'Errico, G., Di Carlo, M., Fattorini, D., et al. (2016). Oxidative responsiveness to multiple stressors in the key Antarctic species, Adamussium colbecki: interactions between temperature, acidification and cadmium exposure. Mar. Environ. Res. 121, 20-30. doi: 10. 1016/j.marenvres.2016.03.011

Bertolin, M. L., and Schloss, I. R. (2009). Phytoplankton production after the collapse of the Larsen A Ice Shelf, Antarctica. Polar Biol 32, 1435-1446. doi: 10.1007/s00300-009-0638-x

Borisenko, Y., and Gontar, V. I. (1991). Biogeochemistry of skeletons of coldwater Bryozoa. Biol. Morya 1, 80-90.

Brandt, A. (1991). Zur Besiedlungsgeschichte des antarktischen Schelfes am Beispiel der Isopoda (Crustacea, Malacostraca). Berich. Polarforsch. 98, $1-240$.

Brandt, A. (1999). On the origin and evolution of Antarctic Peracarida (Crustacea. Malacostraca). Sci. Mar. 63, 261-274. doi: 10.3989/scimar.1999.63s 1261

Brandt, A., Bathmann, U., Brix, S., Cisewski, B., Flores, H., Göcke, C., et al. (2011). Maud Rise - A snapshot through the water column. Deep Sea Res. II. 58, 1962-1982. doi: 10.1016/j.dsr2.2011.01.008

Brandt, A., De Broyer, C., Ebbe, B., Ellingsen, K. E., Gooday, A. J., Janussen, D., et al. (2012). "Southern Ocean deep benthic biodiversity," in Antarctic Ecosystems: An Extreme Environment in a Changing World, eds A. D. Rogers, N. M. Johnston, E. J. Murphy, and A. Clarke. (Oxford: Blackwell Publishing Ltd.), 291-334. doi: $10.1111 /$ gcb.12337

Brandt, A., Ellingsen, K. E. E., Brix, S., Brökeland, W., and Malyutina, M. (2005). Southern Ocean deep-sea isopod species richness (Crustacea, Malacostraca): influences of depth, latitude and longitude. Polar Biol. 28, 284-289. doi: 10. 1007/s00300-004-0688-z

Brandt, A., Gooday, A. J., Brix, S. B., Brökeland, W., Cedhagen, T., Choudhury, M., et al. (2007). The Southern Ocean deep sea: first insights into biodiversity and biogeography. Nature 447, 307-311. doi: 10.1038/nature05827 
Brandt, A., and Gutt, J. (2011). "Biodiversity of a unique environment: the Southern Ocean benthos shaped and threatened by climate change," in Biodiversity Hotspots, eds F. Zachos and J. Habel (Berlin: Springer), 503-526. doi: 10.1007/ 978-3-642-20992-5_25

Brandt, A., Linse, K., and Mühlenhardt-Siegel, U. (1999). Biogeography of Crustacea and Mollusca of the magellan and Antarctic region. Sci. Mar. 63, 383-389. doi: 10.3989/scimar.1999.63s1383

Brasier, M. J., Constable, A., Melbourne-Thomas, J., Trebilco, R., Griffiths, H., Van de Putte, A., et al. (2019). Observations and models to support the first Marine Ecosystem Assessment for the Southern Ocean (MEASO). J. Marine Syst. 197:103182. doi: 10.1016/j.jmarsys.2019.05.008

Brasier, M. J., Grant, S. M., Trathan, P. N., Allcock, L., Ashford, O., Blagbrough, H., et al. (2018). Benthic biodiversity in the South Orkney Islands Southern shelf marine protected area. Biodiversity 19, 5-19. doi: 10.1080/14888386.2018. 1468821

Brasier, M. J., Wiklund, H., Neal, L., Jeffreys, R., Linse, K., Ruhl, H., et al. (2016). DNA barcoding uncovers cryptic diversity in $50 \%$ of deep-sea Antarctic polychaetes. R. Soc. Open Sci. 3:160432. doi: 10.1098/rsos.160432

Brey, T., Dahm, C., Gorny, M., Klages, M., Stiller, M., and Arntz, W. E. (1996). Do Antarctic benthic invertebrates show an extended level of eurybathy? Antarct. Sci. 8, 3-6. doi: 10.1017/s0954102096000028

Brooks, C. M., Crowder, L. B., Österblom, H., and Strong, A. L. (2020). Reaching consensus for conserving the global commons: the case of the Ross Sea, Antarctica. Conserv. Lett. 13:e12676. doi: 10.1371/journal.pone.023 1361

Brown, K. E., King, C. K., and Harrison, P. L. (2017). Lethal and behavioral impacts of diesel and fuel oil on the Antarctic amphipod Paramoera walkeri. Environ. Toxicol. Chem. 36, 2444-2455. doi: 10.1002/etc.3778

Browne, M. A., Underwood, A. J., Chapman, M. G., Williams, R., Thompson, R. C., and van Franeker, J. A. (2015). Linking effects of anthropogenic debris to ecological impacts. P. Roy. Soc. B-Biol. Sci. 282:20142929. doi: 10.1098/rspb. 2014.2929

Bylenga, C. H., Cummings, V. J., and Ryan, K. G. (2015). Fertilisation and larval development in an Antarctic bivalve, Laternula elliptica, under reduced $\mathrm{pH}$ and elevated temperatures. Mar. Ecol. Prog. Ser. 536, 187-201. doi: 10.3354/ meps11436

Bylenga, C. H., Cummings, V. J., and Ryan, K. G. (2017). High resolution microscopy reveals significant impacts of ocean acidification and warming on larval shell development in Laternula elliptica. PLoS One 12:e0175706. doi: 10.1371/journal.pone.0175706

Byrne, M. (2011). Impact of ocean warming and ocean acidification on marine invertebrate life history stages: vulnerabilities and potential for persistence in a changing ocean. Oceanogr. Mar. Biol. 49, 1-42.

Cairns, S. D., and Macintyre, I. G. (1992). Phylogenetic implications of calcium carbonate mineralogy in the Stylasteridae (Cnidaria: Hydrozoa). Palaios 7 , 96-107. doi: 10.2307/3514799

Caldeira, K., and Wickett, M. E. (2005). Ocean model predictions of chemistry changes from carbon dioxide emissions to the atmosphere and ocean. J. Geophys. Res. 110, 1-12.

Cape, M. R., Vernet, M., Kahru, M., and Spreen, G. (2014). Polynya dynamics drive primary production in the Larsen A and B embayments following iceshelf collapse. J. Geophys. Res. Oceans 119, 572-594. doi: 10.1002/2013JC00 9441

Cárdenas, L., Leclerc, J. C., Bruning, P., Garrido, I., Détrée, C., Figueroa, A., et al. (2020). First mussel settlement observed in Antarctica reveals the potential for future invasions. Sci. Rep. 10, 1-8. doi: 10.1038/s41598-020-62340-0

Cavanagh, R. D., Melbourne-Thomas, J., Grant, S. M., Barnes, D. K. A., Hughes, K. A., Halfter, S., et al. (2020). Future risk for Southern Ocean ecosystem services under climate change. Front. Mar. Sci. 7:1224. doi: 10.3389/fmars.2020. 615214

CCAMLR (2008). Conservation Measure 22-05 (2008). Restrictions on the Use of Bottom Trawling Gear in High-Seas Areas of the Convention Area. Hobart, TAS: CCAMLR.

CCAMLR (2009a). Conservation Measure 22-08 (2009). Prohibition on Fishing for Dissostichus spp. In Depths Shallower than $550 \mathrm{~m}$ in Exploratory Fisheries. Hobart, TAS: CCAMLR.

CCAMLR (2009b). Report of the Workshop on Vulnerable Marine Ecosystems ( $\mathrm{La}$ Jolla, CA, USA 3 to 7 August 2009). Hobart, TAS: CCAMLR.
CCAMLR (2009c). CCAMLR VME Taxa Classification guide 2009 Hobart, Australia. Available online at: https://www.ccamlr.org/en/document/ publications/vme-taxa-classification-guide (accessed February 4, 2020).

CCAMLR (2019a). Conservation Measure 22-07 (2013). Interim Measure for Bottom Fishing Activities Subject to Conservation Measure 22-06 Encountering Potential Vulnerable Marine Ecosystems in the Convention Area. Schedule of Conservation Measures in Force 2019/20. Hobart, TAS: CCAMLR.

CCAMLR (2019b). CCAMLR VME Registry. Hobart, TAS: CCAMLR.

CCAMLR (2020). Report of the Thirty-Ninth Meeting of the Commission (Virtual Meeting, 26 to 30 October 2020). Hobart, TAS: CCAMLR.

Chapelle, G., and Peck, L. S. (1999). Polar gigantism dictated by oxygen availability. Nature 399, 114-155. doi: 10.1038/20099

Clark, D., Lamare, M., and Barker, M. (2009). Response of sea urchin pluteus larvae (Echinodermata: Echinoidea) to reduced seawater $\mathrm{pH}$ : a comparison among a tropical, temperate, and a polar species. Mar. Biol. 156, 1125-1137. doi: 10.1007/s00227-009-1155-8

Clark, G. F., Raymond, B., Riddle, M. J., Stark, J. S., and Johnston, E. L. (2015). Vulnerability of shallow Antarctic invertebrate-dominated ecosystems. Austr. Ecol. 40, 482-491. doi: 10.1111/aec.12237

Clark, G. F., Stark, J. S., Johnston, E. L., Runcie, J. W., Goldsworthy, P. M., Raymond, B., et al. (2013). Light-driven tipping points in polar ecosystems. Glob. Change Biol. 19, 3749-3376. doi: 10.1111/gcb.12337

Clark, G. F., Stark, J. S., Palmer, A. S., Riddle, M. J., and Johnston, E. L. (2017). The roles of sea-ice, light and sedimentation in structuring shallow Antarctic benthic communities. PLoS One 12:e0168391. doi: 10.1371/journal. pone. 0168391

Clarke, A., and Johnston, N. M. (2003). "Antarctic marine benthic diversity," in Oceanography and Marine Biology, An Annual Review, Vol. 41, eds R. N. Gibson and J. A. Atkinson (Boca Raton, FL: CRC Press), 55-57.

Coggon, R. M., Teagle, D. A., Smith-Duque, C. E., Alt, J. C., and Cooper, M. J. (2010). Reconstructing past seawater $\mathrm{Mg} / \mathrm{Ca}$ and $\mathrm{Sr} / \mathrm{Ca}$ from mid-ocean ridge flank calcium carbonate veins. Science 327, 1114-1117. doi: 10.1126/science. 1182252

Conlan, K. E., Kim, S. L., Lenihan, H. S., and Oliver, J. S. (2004). Benthic changes during 10 years of organic enrichment by McMurdo Station, Antarctica. Mar. Pollut. Bull. 49, 43-60. doi: 10.1016/j.marpolbul.2004.01.007

Constable, A. J. (2011). Lessons from CCAMLR on the implementation of the ecosystem approach to managing fisheries. Fish Fisher. 12, 138-151. doi: 10. 1111/j.1467-2979.2011.00410.x

Constable, A. J., de la Mare, W. K., Agnew, D. J., Everson, I., and Miller, D. (2000). Managing fisheries to conserve the Antarctic marine ecosystem: practical implementation of the Convention on the Conservation of Antarctic Marine Living Resources (CCAMLR). ICES J. Mar. Sci. 57, 778-791. doi: 10.1006/jmsc. 2000.0725

Constable, A. J., and Welsford, D. C. (2011). "Developing a precautionary, ecosystem approach to managing fisheries and other marine activities at Heard Island and McDonald Islands in the Indian Sector of the Southern Ocean," in The Kerguelen Plateau: Marine Ecosystem and Fisheries, eds G. Duhamel and D. C. Welsford (Paris: Société Française d'Ichtyologie), 233-255.

Cook, A. J., Fox, A. J., Vaughan, D. G., and Ferrigno, J. G. (2005). Retreating glacier fronts on the Antarctic Peninsula over the past half-century. Science 308, 541-544. doi: 10.1126/science.1104235

Corbett, P., King, C., Stark, J. S., and Mondon, J. (2014). Direct evidence of histopathological impacts of wastewater discharge on resident Antarctic fish (Trematomus bernacchii) at Davis Station, East Antarctica. Mar. Pollut. Bull. 87, 48-56. doi: 10.1016/j.marpolbul.2014.08.012

Cross, E. L., Harper, E. M., and Peck, L. S. (2019). Thicker shells compensate extensive dissolution in brachiopods under future ocean acidification. Environ. Sci. Technol. 53, 5016-5026. doi: 10.1021/acs.est.9b00714

Cross, E. L., Peck, L. S., and Harper, E. M. (2015). Ocean acidification does not impact shell growth or repair of the Antarctic brachiopod Liothyrella uva (Broderip, 1833). J. Exp. Mar. Biol. Ecol. 462, 29-35. doi: 10.1016/j.jembe.2014. 10.013

Cummings, V., Hewitt, J., Van Rooyen, A., Currie, K., Beard, S., Thrush, S., et al. (2011). Ocean acidification at high latitudes: potential effects on functioning of the antarctic bivalve Laternula elliptica. PLoS One 6:e16079. doi: 10.1371/ journal.pone.0016069 
Dayton, P., Jarrell, S., Kim, S., Thrush, S., Hammerstrom, K., Slattery, M., et al. (2016). Surprising episodic recruitment and growth of Antarctic sponges: implications for ecological resilience. J. Exp. Mar. Biol. Ecol. 482, 38-55. doi: 10.1016/j.jembe.2016.05.001

Dayton, P. K. (1990). "Polar benthos," in Polar Oceanography, Part B: Chemistry, Biology, and Geology, ed. W. O. Smith (San Diego, CA: Academic Press), 631-685. doi: 10.1016/b978-0-08-092595-0.50010-6

Dayton, P. K., Jarrell, S. C., Kim, S., Parnell, P., Thrush, S. F., Hammerstrom, K., et al. (2019). Benthic responses to an Antarctic regime shift: food particle size and recruitment biology. Ecol. Appl. 29:e01823. doi: 10.1002/eap.1823

Dell'Acqua, O., Trębala, M., Chiantore, M., and Hannula, S.-P. (2019). Robustness of Adamussium colbecki shell to ocean acidification in a short-term exposure. Mar. Environ. Res. 149, 90-99. doi: 10.1016/j.marenvres.2019.06.010

Deregibus, D., Quartino, M. L., Campana, G. L., Momo, F. R., Wiencke, C., and Zacher, K. (2016). Photosynthetic light requirements and vertical distribution of macroalgae in newly ice-free areas in Potter Cove, South Shetland Islands, Antarctica. Polar Biol. 39, 153-166. doi: 10.1007/s00300-015-1679-y

DeVries, A. L. (1971). "Freezing resistance in fishes," in Fish Physiology: Environmental Relations and Behavior, Vol. 6, eds W. A. Hoar and D. J. Randall (London: Academic Press), 157-190. doi: 10.1016/s1546-5098(08)60 148-x

Domack, E., Duran, D., Leventer, A., Ishman, S. E., Doane, S., Mccallum, S., et al. (2005a). Stability of the larsen B ice shelf on the antarctic peninsula during the holocene epoch. Nature 436, 681-685. doi: 10.1038/nature03908

Domack, E., Ishman, S., Leventer, A., Sylva, S., Willmott, V., and Huber, B. (2005b). A chemotrophic ecosystem found beneath the Antarctic Ice Shelf. EOS Transact. Am. Geophys. Uni. 86, 269-276. doi: 10.1029/2005eo290001

Domack, E., O’brien, P. E., Harris, P. T., Taylor, F., Quilty, P. G., De Santis, L., et al. (1998). Late quaternary sediment facies in Prydz Bay, East Antarctica and their relationship to glacial advance onto the continental shelf. Antarct. Sci. 10, 236-246. doi: 10.1017/S0954102098000339

Douglas, E. J., Pilditch, C. A., Kraan, C., Schipper, L. A., Lohrer, A. M., and Thrush, S. F. (2017). Macrofaunal functional diversity provides resilience to nutrient enrichment in coastal sediments. Ecosystems 20, 1324-1336. doi: 10. 1007/s10021-017-0113-4

Douglass, L. L., Beaver, D., Raymond, B., Constable, A. J., Brandt, A., and Post, A. L. (2014a). "Benthic regional classification," in Biogeographic Atlas of the Southern Ocean, eds C. de Broyer, P. K. Koubbi, H. J. Griffiths, B. Raymond, C. d’Udekem d'Acoz, A. Van de Putte, et al. (Cambridge: Scientific Committee on Antarctic Research), 414-417.

Douglass, L. L., Turner, J., Grantham, H. S., Kaiser, S., Constable, A., Nicoll, R., et al. (2014b). A hierarchical classification of benthic biodiversity and assessment of protected areas in the Southern Ocean. PLoS One 9:e100551. doi: 10.1371/ journal.pone.0100551

Dowdeswell, J. A., and Bamber, J. L. (2007). Keel depths of modern Antarctic icebergs and implications for sea-floor scouring in the geological record. Mar. Geol. 243, 120-131. doi: 10.1016/j.margeo.2007.04.008

Duprat, L. P. A. M., Bigg, G. R., and Wilton, D. J. (2016). Enhanced Southern Ocean marine productivity due to fertilization by giant icebergs. Nat. Geosci. 9, 219-221. doi: 10.1038/NGEO2633

Duquesne, S., and Riddle, M. J. (2002). Biological monitoring of heavy metal contamination in coastal waters in the vicinity of Casey Station, Windmill Islands, East Antarctica. Polar Biol. 25, 206-215. doi: 10.1007/s00300-0010328-9

Ericson, J. A., Ho, M. A., Miskelly, A., King, C. K., Virtue, P., Tilbrook, B., et al. (2012). Combined effects of two ocean change stressors, warming and acidification, on fertilization and early development of the Antarctic echinoid Sterechinus neumayeri. Polar Biol. 35, 1027-1034. doi: 10.1007/s00300-0111150-7

Fabri-Ruiz, S., Danis, B., Navarro, N., Koubbi, P., Laffont, R., and Saucède, T. (2020). Benthic ecoregionalization based on echinoid fauna of the southern ocean supports current proposals of antarctic marine protected areas under IPCC scenarios of climate change. Glob. Change Biol. 26, 2161-2180. doi: 10. $1111 /$ gcb. 14988

Fabry, V. J. (2008). Marine calcifiers in a High-CO2 ocean. Science 320, 1020-1022. doi: $10.1126 /$ science. 1157130

Fahrig, L. (2003). Effects of habitat fragmentation on biodiversity. Annu. Rev. Ecol. Syst. 34, 487-515. doi: 10.1146/annurev.ecolsys.34.011802.132419
Fang, C., Zheng, R., Zhang, Y., Hong, F., Mu, J., Chen, M., et al. (2018). Microplastic contamination in benthic organisms from the Arctic and sub-Arctic regions. Chemosphere 209, 298-306. doi: 10.1016/j.chemosphere.2018.06.101

Feely, R. A., Sabine, C. L., Lee, K., Berelson, W., Kleypas, J., Fabry, V. J., et al. (2004). Impact of anthropogenic $\mathrm{CO}_{2}$ on the $\mathrm{CaCO}_{3}$ system in the oceans. Science 305, 362-366. doi: 10.1126/science.1097329

Figuerola, B., Barnes, D. K. A., Brickle, P., and Brewin, P. D. (2017). Bryozoan diversity around the falkland and south georgia islands: overcoming antarctic barriers. Mar. Environ. Res. 126, 81-94. doi: 10.1016/j.marenvres.2017. 02.005

Figuerola, B., Gordon, D. P., Polonio, V., Cristobo, J., and Avila, C. (2014). Cheilostome bryozoan diversity from the southwest Atlantic region: is Antarctica really isolated? J. Sea Res. 85, 1-17. doi: 10.1016/j.seares.2013.09.003

Figuerola, B., Gore, D. B., Johnstone, G., and Stark, J. S. (2019). Spatio-temporal variation of skeletal $\mathrm{Mg}$-calcite in Antarctic marine calcifiers. PLoS One 14:e0210231. doi: 10.1371/journal.pone.0210231

Figuerola, B., Hancock, A. M., Bax, N., Cummings, V., Downey, R., Griffiths, H. J., et al. (2021). A review and meta-analysis of potential impacts of ocean acidification on marine calcifiers from the Southern Ocean. Front. Mar. Sci. 29:584445. doi: 10.3389/fmars.2021.584445

Figuerola, B., Kuklinski, P., and Taylor, P. (2015). Depth patterns in Antarctic bryozoan skeletal $\mathrm{Mg}$-calcite: can they provide an analogue for future environmental changes? Mar. Ecol. Prog. Ser. 540, 109-120. doi: 10.3354/ meps11515

Fillinger, L., Janussen, D., Lundälv, T., and Richter, C. (2013). Rapid Glass sponge expansion after climate-induced antarctic ice shelf collapse. Curr. Biol. 23, 1-5. doi: 10.1016/j.cub.2013.05.051

Foo, S. A., Sparks, K. M., Uthicke, S., Karelitz, S., Barker, M., Byrne, M., et al. (2016). Contributions of genetic and environmental variance in early development of the Antarctic sea urchin Sterechinus neumayeri in response to increased ocean temperature and acidification. Marine Biol. 163:130. doi: 10.1007/s00227-0162903-1

Frederich, M., Sartoris, F. J., and Pörtner, H. O. (2001). Distribution patterns of decapod crustaceans in polar areas: a result of magnesium regulation? Polar Biol. 24, 719-723. doi: 10.1007/978-3-642-59419-9_32

Gonzalez-Bernat, M. J., Lamare, M., and Barker, M. (2013). Effects of reduced seawater $\mathrm{pH}$ on fertilisation, embryogenesis and larval development in the Antarctic seastar Odontaster validus. Polar Biol. 36, 235-247. doi: 10.1007/ s00300-012-1255-7

Goss, H., Jaskiel, J., and Rotjan, R. (2018). Thalassia testudinum as a potential vector for incorporating microplastics into benthic marine food webs. Mar. Pollut. Bull. 135, 1085-1089. doi: 10.1016/j.marpolbul.2018. 08.024

Grange, L. J., and Smith, C. R. (2013). Megafaunal communities in rapidly warming fjords along the West Antarctic Peninsula: hotspots of abundance and beta diversity. PLoS One 8:e77917. doi: 10.1371/journal.pone.007 7917

Grant, R. A., Griffiths, H. J., Steinke, D., Wadley, V., and Linse, K. (2011). Antarctic DNA barcoding; a drop in the ocean? Polar Biol. 34, $775-780$.

Grant, S. M., Waller, C. L., Morley, S. A., Barnes, D. K. A., Brasier, M. J., Double, M. C., et al. (in review). Local drivers of change in Southern Ocean ecosystems: human activities and policy implications. Front. Mar. Sci.

Griffiths, H. J. (2010). Antarctic marine biodiversity-what do we know about the distribution of life in the Southern Ocean? PLoS One 5:e11683. doi: 10.1371/ journal.pone.0011683

Griffiths, H. J., Meijers, A. J., and Bracegirdle, T. J. (2017). More losers than winners in a century of future Southern Ocean seafloor warming. Nature Clim. Change 7, 749-754. doi: 10.1038/nclimate3377

Griffiths, H. J., Whittle, R. J., Roberts, S. J., Belchier, M., and Linse, K. (2013). Antarctic crabs: invasion or endurance? PLoS One 8:e66981. doi: 10.1371/ journal.pone.0066981

Gröndahl, F., Sidenmark, J., and Thomsen, A. (2009). Survey of waste water disposal practices at antarctic research stations. Polar Res. 28, 298-306. doi: 10.1111/j.1751-8369.2008.00056.x

Guinotte, J. M., and Fabry, V. J. (2008). Ocean acidification and its potential effects on marine ecosystems. Ann. N. Y. Acad. Sci. 1134, 320-342. doi: 10.1196/annals. 1439.013 
Gutt, J. (2007). Antarctic macro-zoobenthic communities: a review and an ecological classification. Antarct. Sci. 19, 165-182. doi: 10.1017/S095410200 7000247

Gutt, J., Arndt, J., Kraan, C., Dorschel, B., Schröder, M., Bracher, A., et al. (2019). Benthic communities and their drivers: A spatial analysis off the Antarctic Peninsula. Limnol. Oceanogr. 64, 2341-2357. doi: 10.1002/lno. 11187

Gutt, J., Barratt, I., Domack, E., d’Udekem, d'Acoz, C., Dimmler, W., et al. (2011). Biodiversity change after climate-induced ice-shelf collapse in the Antarctic. Deep Sea Res. II 58, 74-83. doi: 10.1016/j.dsr2.2010.05.024

Gutt, J., Bertler, N., Bracegirdle, T. J., Buschmann, A., Comiso, J., Hosie, G., et al. (2015). The Southern Ocean ecosystem under multiple climate stresses - an integrated circumpolar assessment. Glob. Chang. Biol. 21, 1434-1453. doi: 10.1111/geb.12794

Gutt, J., Cape, M., Dimmler, W., Fillinger, L., Isla, E., Lieb, V., et al. (2013). Shifts in Antarctic megabenthic structure after ice-shelf disintegration in the Larsen area east of the Antarctic Peninsula. Polar Biol. 36, 895-906. doi: 10.1007/s00300013-1315-7

Gutt, J., Isla, E., Bertler, N., Bodeker, G. E., Bracegirdle, T. J., Cavanagh, R. D., et al. (2018). Cross-disciplinarity in the advance of Antarctic ecosystem research. Mar. Genom. 37, 1-17. doi: 10.1016/j.margen.2017. 09.006

Gutt, J., Isla, E., Xavier, J. C., Adams, B. J., Ahn, I. Y., Cheng, C. H. C., et al. (2020). Antarctic ecosystems in transition-life between stresses and opportunities. Biol. Rev. doi: 10.1111/brv.12679

Gutt, J., Koubbi, P., and Eléaume, M. (2007). Mega-epibenthic diversity off Terre Adélie (Antarctica) in relation to disturbance. Polar Biol. 30, 1323-1329. doi: 10.1007/s00300-007-0293-z

Gutt, J., and Piepenburg, D. (2003). Scale-dependent impact on diversity of Antarctic benthos caused by grounding of icebergs. Mar. Ecol. Progr. Ser. 253, 77-83. doi: 10.3354/meps 253077

Gutt, J., Sirenko, B. I., Smirnov, I. S., and Arntz, W. E. (2004). How many macrozoobenthic species might inhabit the Antarctic shelf? Antarct. Sci. 16, 11-16. doi: 10.1017/S0954102004001750

Gutt, J., and Starmans, A. (2001). Quantification of iceberg impact and benthic recolonisation patterns in the Weddell Sea (Antarctica). Polar Biol. 24, 615-619. doi: 10.1007/978-3-642-59419-9_27

Gutt, J., Zurell, D., Bracegridle, T. J., Cheung, W., Clarke, M. S., Convey, P., et al. (2012). Correlative and dynamic species distribution modelling for ecological predictions in the Antarctic: a cross-disciplinary concept. Polar Res. 31:11091. doi: 10.3402/polar.v31i0.11091

Hancock, A. M., King, C. K., Stark, J. S., McMinn, A., and Davidson, A. T. (2020). Effects of ocean acidification on Antarctic marine organisms: a meta-analysis. Ecol. Evol. 10, 4495-4514. doi: 10.1002/ece3.6205

Harris, P. T., and O’Brien, P. E. (1996). Geomorphology and sedimentology of the continental shelf adjacent to Mac. Robertson Land, East Antarctica: a scalped shelf. Mar. Geo. Lett. 16, 287-296. doi: 10.1007/bf01245559

Hauquier, F., Ballesteros-Redondo, L., Gutt, J., and Vanreusel, A. (2016). Community dynamics of nematodes after Larsen ice-shelf collapse in the eastern Antarctic Peninsula. Ecol. Evol. 6, 305-317. doi: 10.1002/ece3.1869

Hauquier, F., Ingels, J., Gutt, J., Raes, M., and Vanreusel, A. (2011). Characterisation of the nematode community of a low-activity cold seep in the recently ice-shelf free Larsen B area, Eastern Antarctic Peninsula. PLoS One 6:e0022240.

Hauri, C., Friedrich, T., and Timmermann, A. (2016). Abrupt onset and prolongation of aragonite undersaturation events in the Southern Ocean. Nat. Clim. Change 6, 172-176. doi: 10.1038/nclimate2844

Havermans, C., Nagy, Z. T., Sonet, G., De Broyer, C., and Martin, P. (2011). DNA barcoding reveals new insights into the diversity of Antarctic species of Orchomene sensu lato (Crustacea: Amphipoda: Lysianassoidea). Deep Sea Res. II 58, 230-241. doi: 10.1016/j.dsr2.2010.09.028

Held, C. (2003). "Molecular evidence for cryptic speciation within the widespread Antarctic crustacean Ceratoserolis trilobitoides (Crustacea, Isopoda)," in Antarctic Biology in a Global Context, eds A. H. L. Huiskes, W. W. C. Gieskes, J. Rozema, R. M. L. Schorno, S. M. van der Vies, and W. J. Wolff (Leiden: Backhuys Publishers), 1-5.

Hellberg, M. E., Aronson, R. B., Smith, K. E., Duhon, M. I., Ahyong, S. T., Lovrich, G. A., et al. (2019). Population expansion of an Antarctic king crab? Front. Biogeogr 11:e43165. doi: 10.21425/F5FBG43165
Holland, O., Shaw, J., Stark, J., and Wilson, K. (in press). Hull fouling marine invasive species pose a very low, but plausible, risk of introduction to East Antarctica in climate change scenarios. Divers. Distrib.

Hughes, K. A., and Nobbs, S. J. (2004). Long-term survival of human faecal microorganisms on the Antarctic Peninsula. Antarct. Sci. 16, 293-297. doi: 10.1017/S095410200400210X

Hughes, K. A., Pescott, O. L., Peyton, J., Adriaens, T., Cottier-Cook, E. J., Key, G., et al. (2020). Invasive non-native species likely to threaten biodiversity and ecosystems in the Antarctic Peninsula region. Glob. Change Biol. 26, 2702-2716. doi: $10.1111 /$ gcb. 14938

Hughes, K. A., and Thompson, A. (2004). Distribution of sewage pollution around a maritime Antarctic research station indicated by faecal coliforms, Clostridium perfringens and faecal sterol markers. Environ. Pollut. 127, 315-321. doi: 10. 1016/j.envpol.2003.09.004

Hyland, J., Laur, D., Jones, J., Shrake, J., Cadian, D., and Harris, L. (1994). Effects of an oil spit on the soft-bottom macrofaunal of Arthur Harbour, Antarctica compared with long-term natural change. Antarct. Sci. 6, 37-44. doi: 10.1017/ S0954102094000052

IAATO (2012). IAATO Marine Safety Notice 2012.02. IAATO Field Operations Manual. South Kingstown: IAATO.

IAATO (2019a). Antarctica Tour Operators Introduce New Measures to Manage for Tourism Growth. News release: International Association of Antarctic Tour Operators. Cape Town, South Africa. 3 May 2019. South Kingstown: IAATO,

IAATO (2019b). IAATO Field Operations Manual (FOM). XLII Antarctic Treaty Consultative Meeting. ATCM 17, IP 144. Prague: IAATO.

Ingels, J., Aronson, R. B., Smith, C. R., Baco, A., Bik, H. M., Blake, J. A., et al. (2020). Antarctic ecosystem responses following ice-shelf collapse and iceberg calving: Science review and future research. Wiley Interdiscip. Rev. Clim. Change 12:e682. doi: 10.1002/wcc.682

IPCC (2014). Climate Change 2014: Synthesis Report. Contribution of Working Groups I, II and III to the Fifth Assessment Report of the Intergovernmental Panel on Climate Change, Core Writing Team, eds R. K. Pachauri and L. A. Meyer (Geneva: IPCC).

Janosik, A. M., and Halanych, K. M. (2010). Unrecognized antarctic biodiversity: a case study of the genus Odontaster (Odontasteridae; Asteroidea). Integr. Comp. Biol. 50, 981-992. doi: 10.1093/icb/icq119

Jansen, J., Dunstan, P. K., Hill, N. A., Koubbi, P., Melbourne-Thomas, J., Causse, R., et al. (2019). Integrated assessment of the spatial distribution and structural dynamics of deep benthic marine communities. Ecol. Appl. 19:2065. doi: 10. 1002/eap.2065

Jansen, J., Hill, N. A., Dunstan, P. K., Cougnon, E. A., Galton-Fenzi, B. K., and Johnson, C. R. (2018). Mapping Antarctic suspension feeder abundances and seafloor food-availability and modelling their change after a major glacier calving. Front. Ecol. Evol. 18:94. doi: 10.3389/fevo.2018.00094

Johst, K., Gutt, J., Wissel, C., and Grimm, V. (2006). Diversity and disturbances in the Antarctic megabenthos: feasible versus theoretical disturbance ranges. Ecosystems 9, 1145-1155. doi: 10.1007/s10021-006-0054-9

Jones, C. D., Lockhart, S., and Ramm, D. (2016). “Antarctic and Southern Ocean," in Vulnerable Marine Ecosystems, Processes and Practices in the High Seas, eds A. Thompson, J. Sanders, M. Tandstad, F. Carocci, and J. Fuller (Rome: FAO Fisheries and Aquaculture), 159-176.

Jones, C. D., and Lockhart, S. J. (2011). Detecting vulnerable marine ecosystems in the southern ocean using research trawls and underwater imagery. Mar. Policy 35, 732-736. doi: 10.1016/j.marpol.2011.02.004

Jones, D. O., Bett, B. J., and Tyler, P. A. (2007). Depth-Related changes to density, diversity and structure of benthic megafaunal assemblages in the fimbul ice shelf region, Weddell Sea, Antarctica. Polar Biol. 30, 579-592. doi: 10.1007/s00300007-0319-6

Jones, D. O. B., Yool, A., Wei, C.-L., Henson, S. A., Ruhl, H. A., Watson, R. A., et al. (2014). Global reductions in seafloor biomass in response to climate change. Glob. Chang. Biol. 20, 1861-1872. doi: 10.1111/gcb.12480

Kaiser, S., Brandão, S. N., Brix, S., Barnes, D. K., Bowden, D. A., Ingels, J., et al. (2013). Patterns, processes and vulnerability of Southern Ocean benthos: a decadal leap in knowledge and understanding. Mar. Biol. 160, 2295-2317. doi: 10.1007/s00227-013-2232-6

Kaiser, S., Griffiths, H. J., Barnes, D. K., Brandão, S. N., Brandt, A., and O’Brien, P. E. (2011). Is there a distinct continental slope fauna in the Antarctic? Deep Sea Res. II 58, 91-104. doi: 10.1016/j.dsr2.2010.05.017 
Karelitz, S. E., Uthicke, S., Foo, S. A., Barker, M. F., Byrne, M., Pecorino, D., et al. (2017). Ocean acidification has little effect on developmental thermal windows of echinoderms from Antarctica to the tropics. Glob. Chang. Biol. 23, 657-672. doi: $10.1111 /$ gcb.13452

Kefford, B., King, C., Wasley, J., Riddle, M., and Nugegoda, D. (2019). Sensitivity of a large and representative sample of Antarctic marine invertebrates to metals. Environ. Toxicol. Chem. 38, 1560-1568. doi: 10.1002/etc.4419

Kennicutt, M. C. II, Chown, S. L., Cassano, J. J., Liggett, D., Peck, L. S., Massom, R., et al. (2014). A roadmap for Antarctic and Southern Ocean science for the next two decades and beyond. Antarct Sci. 27, 3-18. doi: 10.1017/ S0954102014000674

Kim, S., Hammerstrom, K., and Dayton, P. (2019). Epifauna community response to iceberg-mediated environmental change in McMurdo Sound, Antarctica. Mar. Ecol. Progr. Ser. 613, 1-14. doi: 10.3354/meps12899

Kock, K.-H. (1992). Antarctic Fish and Fisheries. Cambridge: Cambridge University Press.

Kortsch, S., Primicerio, R., Beuchel, F., Renaud, P. E., Rodrigues, J., Lønne, O. J., et al. (2012). Climate-driven regime shifts in Arctic marine benthos. Proc. Natl. Acad. Sci. U.S.A. 109, 14052-14057. doi: 10.1073/pnas.1207509109

Krabbe, K., Leese, F., Mayer, C., Tollrian, R., and Held, C. (2010). Cryptic mitochondrial lineages in the widespread pycnogonid Colossendeis megalonyx Hoek, 1881 from Antarctic and Subantarctic waters. Polar Biol. 33, 281-292. doi: 10.1007/s00300-009-0703-5

Kriwoken, L. K., and Rootes, D. (2000). Tourism on ice: environmental impact assessment of Antarctic tourism. Impact Assess. Proj. Apprais. 18, 138-150. doi: 10.3152/147154600781767538

Lacerda, A. L. D. F., Rodrigues, L. D. S., Van Sebille, E., Rodrigues, F. L., Ribeiro, L., Secchi, E. R., et al. (2019). Plastics in sea surface waters around the Antarctic Peninsula. Sci. Rep. 9:3977. doi: 10.1038/s41598-019-40311-4

Lagger, C., Servetto, N., Torre, L., and Sahade, R. (2017). Benthic colonization in newly ice-free soft-bottom areas in an Antarctic fjord. PLoS One 12:e0186756. doi: 10.1371/journal.pone.0186756

Laudien, J., Herrmann, M., and Arntz, W. E. (2007). Soft bottom species richness and diversity as a function of depth and iceberg scour in Arctic glacial Kongsfjorden (Svalbard). Polar Biol. 30, 1035-1046. doi: 10.1007/s00300-0070263-5

Lee, J. E., and Chown, S. L. (2007). Mytilus on the move: transport of an invasive bivalve to the Antarctic. Marine Ecol. Prog. Ser. 339, 307-310.

Lee, J. E., and Chown, S. L. (2009). Temporal development of hull-fouling assemblages associated with an Antarctic supply vessel. Marine Ecol. Prog. Ser. 386, 97-105. doi: 10.3354/meps08074

Lenihan, H. S., and Oliver, J. S. (1995). Anthropogenic and natural disturbances to marine benthic communities in Antarctica. Ecol. Appl. 5, 311-326.

Lenihan, H. S., Oliver, J. S., Oakden, J. M., and Stephenson, M. D. (1990). Intense and localized benthic marine pollution around McMurdo Station, Antarctica. Mar. Pollut. Bull. 21, 422-430. doi: 10.1016/0025-326x(90)90761-v

Lenihan, H. S., Peterson, C. H., Miller, R. J., Kayal, M., and Potoski, M. (2018). Biotic disturbance mitigates effects of multiple stressors in a marine benthic community. Ecosphere 9:e02314. doi: 10.1002/ecs2.2314

Leung, J. Y. S., Russell, B. D., and Connell, S. D. (2017). Mineralogical plasticity acts as a compensatory mechanism to the impacts of ocean acidification. Envrion. Sci. Technol. 51, 2652-2659. doi: 10.1021/acs.est.6b0 4709

Lewis, P. N., Riddle, M. J., and Hewitt, C. L. (2004). Management of exogenous threats to Antarctica and the sub-Antarctic Islands: balancing risks from TBT and non-indigenous marine organisms. Mar. Pollut. Bull. 49, 999-1005. doi: 10.1016/j.marpolbul.2004.07.001

Linse, K., Cope, T., Lörz, A.-N., and Sands, C. (2007). Is the Scotia Sea a centre of Antarctic marine diversification? Some evidence of cryptic speciation in the circum-Antarctic bivalve Lissarca notorcadensis (Arcoidea: Philobryidae). Polar Biol. 30, 1059-1068. doi: 10.1007/s00300-007-0265-3

Lister, K. N., Lamare, M. D., and Burritt, D. J. (2015). Pollutant resilience in embryos of the Antarctic sea urchin Sterechinus neumayeri reflects maternal antioxidant status. Aquat. Toxicol. 161, 61-72. doi: 10.1002/etc.3679

Lockhart and Hocevar. (accepted). Combined abundance of all Vulnerable Marine Ecosystem indicator taxa inadequate as sole determiner of vulnerability, Antarctic Peninsula. Front. Mar. Sci.
Loxton, J., Kuklinski, P., Barnes, D. K. A., Najorka, J., Jones, M. S., and Porter, J. S. (2014). Variability of Mg-calcite in Antarctic bryozoan skeletons across spatial scales. Mar. Ecol. Prog. Ser. 507, 169-180. doi: 10.3354/meps10826

Lynch, H. J., Crosbie, K., Fagan, W. F., and Naveen, R. (2010). Spatial patterns of tour ship traffic in the Antarctic Peninsula region. Antarct. Sci. 22, 123-130. doi: 10.1017/S0954102009990654

Maksym, T., Stammerjohn, S. E., Ackley, S., and Massom, R. (2012). Antarctic Sea Ice- A Polar Opposite? Oceanography 25, 140-151. doi: 10.5670/oceanog. 2012.88

Margolin, A. R., Robinson, L. F., Burke, A., Waller, R. G., Scanlon, K. M., Roberts, M. L., et al. (2014). Temporal and spatial distributions of cold-water corals in the Drake Passage: insights from the last 35,000 years. Deep Sea Res. II 99, 237-248. doi: 10.1016/j.dsr2.2013.06.008

Marsh, L., Copley, J. T., Huvenne, V. A., Linse, K., Reid, W. D., Rogers, A. D., et al. (2012). Microdistribution of faunal assemblages at deep-sea hydrothermal vents in the Southern Ocean. PLoS One 7:e48348. doi: 10.1371/journal.pone. 0048348

Martinez-Dios, A., Dominguez-Carrió, C., Zapata-Guardiola, R., and Gili, J.-M. (2016). New insights on Antarctic gorgonian's age, growth and their potential as paleorecords. Deep Sea Res. I. 112, 57-67. doi: 10.1016/j.dsr.2016.03.007

Maynou, F., and Cartes, J. (2012). Effects of trawling on fish and invertebrates from deep-sea coral facies of Isidella elongata in the western Mediterranean. J. Mar. Biolog. Assoc. 92, 1501-1507. doi: 10.1017/s0025315411001603

McClintock, J. B., Amsler, M. O., Angus, R. A., Challener, R. C., Schram, J. B., Amsler, C. D., et al. (2011). The Mg-calcite composition of Antarctic echinoderms: Important implications for predicting the impacts of ocean acidification. J. Geol. 119, 457-466. doi: 10.1086/660890

McClintock, J. B., Angus, R. A., Mcdonald, M. R., Amsler, C. D., Catledge, S. A., and Vohra, Y. K. (2009). Rapid dissolution of shells of weakly calcified Antarctic benthic macroorganisms indicates high vulnerability to ocean acidification. Antarct. Sci. 21, 449-456. doi: 10.1017/S0954102009990198

McMinn, A., Pankowskii, A., Ashworth, C., Bhagooli, R., Ralph, P., and Ryan, K. (2010). In situ net primary productivity and photosynthesis of Antarctic sea ice algal, phytoplankton and benthic algal communities. Mar. Biol. 157, 1345-1356. doi: 10.1007/s00227-010-1414-8

Meijers, A. J., Shuckburgh, E., Bruneau, N., Sallee, J. B., Bracegirdle, T. J., and Wang, Z. (2012). Representation of the Antarctic Circumpolar Current in the CMIP5 climate models and future changes under warming scenarios. J. Geophys. Res. Oceans 117:C12. doi: 10.1029/2012JC008412

Menot, L., Galéron, J., Olu, K., Caprais, J. C., Crassous, P., Khripounoff, A., et al. (2010). Spatial heterogeneity of macrofaunal communities in and near a giant pockmark area in the deep Gulf of Guinea. Mar. Ecol. 31, 78-93. doi: 10.1111/j. 1439-0485.2009.00340.x

Morley, S. A., Abele, D., Barnes, D. K., Cardenas, C. A., Cotte, C., Gutt, J., et al. (2020). Global drivers on Southern Ocean ecosystems: changing physical environments and anthropogenic pressures in an Earth system. Front. Mar. Sci. 7:1097. doi: 10.3389/fmars.2020.547188

Morley, S. A., Barnes, D. K., and Dunn, M. J. (2019). Predicting which species succeed in climate-forced polar seas. Front. Mar. Sci. 5:507. doi: 10.3389/fmars. 2018.00507

Morley, S. A., Hirse, T., Pörtner, H. O., and Peck, L. S. (2009). Geographical variation in thermal tolerance within Southern Ocean marine ectotherms. Comp. Biochem. Phys. A. 153, 154-161. doi: 10.1016/j.cbpa.2009.02.001

Morley, S. A., Hirse, T., Thorne, M. A., Pörtner, H. O., and Peck, L. S. (2012a). Physiological plasticity, long term resistance or acclimation to temperature, in the Antarctic bivalve, Laternula elliptica. Comp. Biochem. Phys. A. 162, 16-21. doi: 10.1016/j.cbpa.2012.01.009

Morley, S. A., Martin, S. M., Bates, A. E., Clark, M. S., Ericson, J., Lamare, M., et al. (2012b). Spatial and temporal variation in the heat tolerance limits of two abundant Southern Ocean invertebrates. Mar. Ecol. Prog. Ser. 450, 81-92. doi: 10.3354/meps09577

Morley, S. A., Suckling, C. S., Clark, M. S., Cross, E. L., and Peck, L. S. (2016). Long-term effects of altered $\mathrm{pH}$ and temperature on the feeding energetics of the Antarctic sea urchin, Sterechinus neumayeri. Biodiversity 17, 34-45. doi: 10.1080/14888386.2016.1174956

Munari, C., Infantini, V., Scoponi, M., Rastelli, E., Corinaldesi, C., and Mistri, M. (2017). Microplastics in the sediments of Terra Nova Bay (Ross Sea, Antarctica). Mar. Pollut. Bull. 122, 161-165. doi: 10.1016/j.marpolbul.2017.06.039 
Neal, L., Wiklund, H., Muir, A. I., Linse, K., and Glover, A. G. (2014). The identity of juvenile Polynoidae (Annelida) in the Southern Ocean revealed by DNA taxonomy, with notes of the status of Herdmanella gracilis Ehlers sensu Augener. Mem. Mus. Vic. 71, 203-216. doi: 10.24199/j.mmv.2014.71.16

Negrete-García, G., Lovenduski, N. S., Hauri, C., Krumhardt, K. M., and Lauvset, S. K. (2019). Sudden emergence of a shallow aragonite saturation horizon in the Southern Ocean. Nature Clim. Change 9, 313-317. doi: 10.1038/s41558-0190418-8

Newman, L., Heil, P., Trebilco, R., Katsumata, K., Constable, A., van Wijk, E., et al. (2019). Delivering sustained, coordinated, and integrated observations of the Southern Ocean for global impact. Front. Mar. Sci. 6:433. doi: 10.3389/fmars. 2019.00433

Niemann, H., Fischer, D., Graffe, D., Knittel, K., Montiel, A., Heilmayer, O., et al. (2009). Biogeochemistry of a low-activity cold seep in the Larsen B area, western Weddell Sea, Antarctica. Biogeosciences 6, 2383-2395. doi: 10.5194/bg-6-23832009

O’Brien, P. E., Post, A. L., and Romeyn, R. (2009). “Antarctic-wide Geomorphology as an aid to habitat mapping and locating Vulnerable Marine Ecosystems," in Science Committee to the Commission of Antarctic Marine Living Resources (SCCAMLR-XXVIII/10) Workshop on Vulnerable Marine Ecosystems (La Jolla, CA: CCAMLR).

Orr, J. C., Fabry, V. J., Aumont, O., Bopp, L., Doney, S. C., Feely, R., et al. (2005). Anthropogenic ocean acidification over the twenty-first century and its impact on calcifying organisms. Nature 437, 681-686. doi: 10.1038/nature04095

Pabis, K., Sicinski, J., and Krymarys, M. (2011). Distribution patterns in the biomass of macrozoobenthic communities in Admiralty Bay (King George Island, South Shetlands, Antarctic). Polar Biol. 34, 489-500. doi: 10.1007/ s00300-010-0903-z

Pasotti, F., Manini, E., Giovannelli, D., Wölfl, A. C., Monien, D., Verleyen, E., et al. (2014). Antarctic shallow water benthos in an area of recent rapid glacier retreat. Mar. Ecol. 36, 716-733. doi: 10.1111/maec.12179

Peck, L. S., Ansell, A. D., Webb, K. E., Hepburn, L., and Burrows, M. (2004). Movements and burrowing activity in the Antarctic bivalve molluscs Laternula elliptica and Yoldia eightsi. Polar Biol. 27, 357-367. doi: 10.1007/s00300-0030588-7

Peck, L. S., Barnes, D. K. A., Cook, A. J., Fleming, A. H., and Clarke, A. (2010). Negative feedback in the cold: ice retreat produces new carbon sinks in Antarctica. Glob. Change Biol. 16, 2614-2623. doi: 10.1111/j.1365-2486.2009. 02071.x

Peck, L. S., Barnes, D. K. A., and Willmott, J. (2005). Responses to extreme seasonality in food supply: diet plasticity in Antarctic brachiopods. Mar. Biol. 147, 453-463. doi: 10.1007/s00227-005-1591-z

Peck, L. S., and Brockington, S. (2013). Growth of the Antarctic octocoral Primnoella scotiae and predation by the anemone Dactylanthus antarcticus. Deep Sea Res. II. 92, 72-78. doi: 10.1016/j.dsr2.2013.01.024

Peck, L. S., Brockington, S., VanHove, S., and Beghyn, M. (1999). Community recovery following catastrophic iceberg impacts in Antarctica. Mar. Ecol. Prog. Ser. 186, 1-8. doi: 10.3354/meps186001

Peck, L. S., Massey, A., Thorne, M. A., and Clark, M. S. (2009). Lack of acclimation in Ophionotus victoriae: brittle stars are not fish. Polar Biol. 32, 399-402. doi: 10.1007/s00300-008-0532-y

Peck, L. S., Webb, K. E., Miller, A., Clark, M. S., and Hill, T. (2008). Temperature limits to activity, feeding and metabolism in the Antarctic starfish Odontaster validus. Mar. Ecol. Prog. Ser. 358, 181-189. doi: 10.3354/meps07336

Polmear, R., Stark, J. S., Roberts, D., and McMinn, A. (2015). The effects of oil pollution on Antarctic benthic diatom communities over 5 years. Mar. Poll. Bull. 90, 33-40. doi: 10.1016/j.marpolbul.2014.11.035

Post, A. L., Lavoie, C., Domack, E. W., Leventer, A., Shevenell, A., and Fraser, A. D. (2017). Environmental drivers of benthic communities and habitat heterogeneity on an East Antarctic shelf. Antarct. Sci. 29, 17-32. doi: 10.1017/ S0954102016000468

Post, A. L., Meijers, A. J. S., Fraser, A. D., Meiners, K. M., Ayers, J., Bindoff, N. L., et al. (2014). "Environmental setting," in Biogeographic Atlas of the Southern Ocean, eds C. De Broyer and P. Koubbi (Cambridge: Scientific Committee on Antarctic Research), 46-64.

Post, A. L., O’Brien, P. E., Beaman, R. J., Riddle, M. J., and De Santis, L. (2010). Physical controls on deep water coral communities on the george $\mathrm{V}$ land slope, East Antarctica. Antarct. Sci. 22, 371-378. doi: 10.1017/S095410201000 0180

Potthoff, M., Johst, K., and Gutt, J. (2006). How to survive as a pioneer species in the Antarctic benthos: Minimum dispersal distance as a function of lifetime and disturbance. Polar Biol. 29, 543-551. doi: 10.1007/s00300-0050086-1

Powell, S. M., Stark, J. S., Snape, I., Woolfenden, E., Bowman, J. P., and Riddle, M. J. (2010). Effects of diesel and lubricant oils on Antarctic benthic microbial communities over five years. Aquat. Microb. Ecol. 61, 119-127. doi: 10.3354/ ame01441

Power, M. L., Samuel, A., Smith, J. J., Stark, J. S., Gillings, M. R., and Gordon, D. M. (2016). Escherichia coli out in the cold: dissemination of human-derived bacteria into the Antarctic microbiome. Environ. Pollut. 215, 58-65. doi: 10. 1016/j.envpol.2016.04.013

Provencher, J. F., Ammendolia, J., Rochman, C. M., and Mallory, M. L. (2018). Assessing plastic debris in aquatic food webs: what we know and don't know about uptake and trophic transfer. Environ. Rev. 999, 1-14. doi: 10.1139/er2018-0079

Quartino, M. L., Deregibus, D., Campana, G. L., Latorre, G. E. J., and Momo, F. R. (2013). Evidence of macroalgal colonization on newly ice-free areas following glacial retreat in Potter Cove (South Shetland Islands), Antarctica. PLoS One 8:e58223. doi: 10.1371/journal.pone.0058223

Ralph, R., Maxwell, J. G. H., Everson, I., and Hall, J. (1976). A record of Mytilus edulis L from South Georgia. Br. Antarct. Surv. Bull. 44, 101-102.

Raupach, M. J., Malyutina, M., Brandt, A., and Wägele, J. W. (2007). Molecular data reveal a highly diverse species flock within the deep-sea isopod Betamorpha fusiformis (Crustacea: Isopoda: Asellota) in the Southern Ocean. Deep Sea Res. II 54, 1820-1830. doi: 10.1016/j.dsr2.2007.07.009

Raymond, T., King, C. K., Raymond, B., Stark, J. S., and Snape, I. (2017). "Oil pollution in Antarctica," in Oil Spill Science and Technology, ed. M. Fingas (Cambridge, MA: Gulf Professional Publishing), 759-804. doi: 10.1016/b9780-12-809413-6.00014-x

Reed, S., Clark, M., Thompson, R., and Hughes, K. A. (2018). Microplastics in marine sediments near Rothera research station, Antarctica. Mar. Pollut. Bull. 13, 460-463. doi: 10.1016/j.marpolbul.2018.05.068

Reid, K., and Croxall, J. P. (2001). Environmental response of upper trophic-level predators reveals a system change in an Antarctic marine ecosystem. Proc. $R$. Soc. B. Biol. Sci. 268, 377-384. doi: 10.1098/rspb.2000.1371

Ries, J. B., Cohen, A. L., and McCorkle, D. C. (2009). Marine calcifiers exhibit mixed responses to CO2-induced ocean acidification. Geology 37, 1131-1134. doi: 10.1130/G30210A.1

Roark, E. B., Guilderson, T. P., Flood-Page, S., Dunbar, R. B., Ingram, B. L., Fallon, S. J., et al. (2005). Radiocarbon-based ages and growth rates of bamboo corals from the Gulf of Alaska. Geophys. Res. Lett. 32:L04606. doi: 10.1029/ 2004GL021919

Robinson, B. J., Barnes, D. K., and Morley, S. A. (2020). Disturbance, dispersal and marine assemblage structure: a case study from the nearshore Southern Ocean. Mar. Environ. Res. 2:105025. doi: 10.1016/j.marenvres.2020.10 5025

Rogers, A. D., Clark, M. R., Hall-Spencer, J. M., and Gjerde, K. M. (2008). The Science Behind the Guidelines: A Scientific Guide to the FAO Draft International Guidelines (December 2007) for the Management of Deep-Sea Fisheries in the High Seas and Examples of how the Guidelines May be Practically Implemented. Gland: IUCN.

Rogers, A. D., Frinault, B. A. V., Barnes, D. K. A., Bindoff, N. L., Downie, R., Ducklow, H. W., et al. (2020). Antarctic futures: an assessment of climatedriven changes in ecosystem structure, function, and service provisioning in the Southern Ocean. Ann. Rev. Mar. Sci. 12, 87-120. doi: 10.1146/annurev-marine010419-011028

Rogers, A. D., Tyler, P. A., Connelly, D. P., Copley, J. T., James, R., Larter, R. D., et al. (2012). The discovery of new deep-sea hydrothermal vent communities in the Southern Ocean and implications for biogeography. PLoS Biol. 10:e1001234. doi: 10.1371/journal.pbio.1001234

Sahade, R., Lagger, C., Torre, L., Momo, F., Monien, P., Schloss, I., et al. (2015). Climate change and glacier retreat drive shifts in an Antarctic benthic ecosystem. Sci. Adv. 1:e1500050. doi: 10.1126/sciadv.1500050 
Sañé, E., Isla, E., Bárcena, M. Á, and Demaster, D. J. (2013). A Shift in the biogenic silica of sediment in the larsen B continental shelf, off the eastern antarctic peninsula, resulting from climate change. PLoS One 8:e52632. doi: 10.1371/ journal.pone.0052632

Scherrer, K. J. N., Kortsch, S., Varpe, Ø, Weyhenmeyer, G. A., Gulliksen, B., and Primicerio, R. (2019). Mechanistic model identifies increasing light availability due to sea ice reductions as cause for increasing macroalgae cover in the Arctic. Limonol. Oceanogr. 54, 330-341. doi: 10.1002/lno.11043

Schram, J. B., Schoenrock, K. M., McClintock, J. B., Amsler, C. D., and Angus, R. A. (2014). Multiple stressor effects of near-future elevated seawater temperature and decreased $\mathrm{pH}$ on righting and escape behaviors of two common Antarctic gastropods. J. Exp. Mar. Biol. Ecol. vol. 457, 90-96. doi: 10.1016/j.jembe.2014. 04.005

Schram, J. B., Schoenrock, K. M., McClintock, J. B., Amsler, C. D., and Angus, R. A. (2016). Testing Antarctic resilience: the effects of elevated seawater temperature and decreased pH on two gastropod species. ICES J. Mar. Sci. 73, 739-752. doi: 10.1093/icesjms/fsv233

Schüller, M. (2011). Evidence for a role of bathymetry and emergence in speciation in the genus Glycera (Glyceridae, Polychaeta) from the deep Eastern Weddell Sea. Polar Biol. 34, 549-564. doi: 10.1007/s00300-0100913-x

Schulz, M., Bergmann, M., von Juterzenka, K., and Soltwedel, T. (2010). Colonisation of hard substrata along a channel system in the deep Greenland Sea. Polar Biol. 33, 1359-1369. doi: 10.1007/s00300-010-0825-9

Seiler, J., and Gutt, J. (2007). Can dead sponges still talk? Antarct Sci. 19, 337-338. doi: 10.1017/S095410200700048X

Sheavly, S. B., and Register, K. M. (2007). Marine debris \& plastics: environmental concerns, sources, impacts and solutions. J. Polym. Environ. 15, 301-305. doi: 10.1007/s10924-007-0074-3

Siciński, J., Pabis, K., Jażdżewski, K., Konopacka, A., and Błażewicz-Paszkowycz, M. J. P. B. (2012). Macrozoobenthos of two Antarctic glacial coves: a comparison with non-disturbed bottom areas. Polar Biol. 35, 355-367. doi: 10.1007/s00300-011-1081-3

Smale, D. A., and Barnes, D. K. A. (2008). Likely responses of the Antarctic benthos to climate-related changes in physical disturbance during the 21 stcentury, based primarily on evidence from the West Antarctic Peninsula region. Ecography 31, 289-305. doi: 10.1111/j.2008.0906-7590.05456.x

Smale, D. A., Brown, K. M., Barnes, D. K. A., Fraser, K. P. P., and Clarke, A. (2008). Ice scour disturbance in Antarctic waters. Science 321:371. doi: 10.1126/science. 1158647

Smith, C. R., DeMaster, D. J., Thomas, C., Sršen, P., Grange, L., Evrard, V., et al. (2012). Pelagic-benthic coupling, food banks, and climate change on the West Antarctic Peninsula Shelf. Oceanogr. 25, 188-201. doi: 10.5670/oceanog.20 12.94

Smith, C. R., Mincks, S., and DeMaster, D. J. (2006). A synthesis of benthopelagic coupling on the Antarctic shelf: food banks, ecosystem inertia and global climate change. Deep Sea Res. Part II Top. Stud. Oceanogr. 53, 875-894. doi: $10.1016 /$ j.dsr2.2006.02.001

Smith, K. L. Jr., Sherman, A. D., Shaw, T. J., and Sprintall, J. (2013). Icebergs as unique Lagrangian ecosystems in polar seas. Annu. Rev. Mar. Sci. 5, 269-287. doi: 10.1146/annurev-marine-121211-172317

Stark, J. S. (2008). Patterns of higher taxon colonisation and development in sessile marine benthic assemblages at Casey Station, Antarctica, and their use in environmental monitoring. Mar. Ecol. Prog. Ser. 365, 77-89. doi: 10.3354/ meps07559

Stark, J. S., Corbett, P. A., Dunshea, G., Johnstone, G., King, C., Mondon, J. A., et al. (2016). The environmental impact of sewage and wastewater outfalls in Antarctica: An example from Davis Station, East Antarctica. Water Res. 105, 602-614. doi: 10.1016/j.watres.2016.09.026

Stark, J. S., Kim, S. L., and Oliver, J. S. (2014). Anthropogenic disturbance and biodiversity of marine benthic communities in antarctica: a regional comparison. PLoS One 9:e98802. doi: 10.1371/journal.pone.009 8802

Stark, J. S., Mohammad, M., McMinn, A., and Ingels, J. (2017). The effects of hydrocarbons on meiofauna in marine sediments in Antarctica. J. Exp. Mar. Biol. Ecol. 496, 56-73. doi: 10.1016/j.jembe.2017.07.009

Stark, J. S., Peltzer, E. T., Kline, D. I., Queirós, A. M., Cox, T. E., Headley, K., et al. (2019). Free Ocean CO2 Enrichment (FOCE) experiments: Scientific and technical recommendations for future in situ ocean acidification projects. Prog. Oceangr. 172, 89-107. doi: 10.1016/j.pocean.2019.01.006

Stark, J. S., Riddle, M. J., and Smith, S. D. A. (2004). Influence of an Antarctic waste dump on recruitment to near-shore marine soft-sediment assemblages. Mar. Ecol. Prog. Ser. 276, 53-70. doi: 10.3354/meps 276053

Stark, J. S., Riddle, M. J., Snape, I., and Scouller, R. C. (2003). Human impacts in Antarctic marine soft-sediment assemblages: correlations between multivariate biological patterns and environmental variables. Estuar. Coast. Shelf Sci. 56, 717-734. doi: 10.1016/S0272-7714(02)00291-3

Stark, J. S., Smith, J., King, C. K., Lindsay, M., Stark, S., Palmer, A. S., et al. (2015). Physical, chemical, biological and ecotoxicological properties of wastewater discharged from Davis Station, Antarctica. Cold Reg. Sci. Technol. 113, 52-62. doi: 10.1016/j.coldregions.2015.02.006

Stark, J. S., Snape, I., Riddle, M. J., and Stark, S. C. (2005). Constraints on spatial variability in soft-sediment communities affected by contamination from an Antarctic waste disposal site. Mar. Pollut. Bull. 50, 276-290. doi: 10.1016/j. marpolbul.2004.10.015

Starmans, A., Gutt, J., and Arntz, W. E. (1999). Mega-epibenthic communities in Arctic and Antarctic shelf areas. Mar. Biol. 135, 269-280. doi: 10.1007/ s002270050624

Suckling, C. S., Clark, M. S., Richard, J., Morley, S. A., Thorne, M. A. S., Harper, E. M., et al. (2015). Adult acclimation to combined temperature and $\mathrm{pH}$ stressors significantly enhances reproductive outcomes compared to short-term exposures. J. Anim. Ecol. 84, 773-784. doi: 10.1111/1365-2656.12316

Syvitski, J. P. M., Farrow, G. E., Atkinson, R. J. A., Moore, P. G., and Andrews, J. T. (1989). Baffin Island Fjord macrobenthos: bottom communities and environmental significance. Arctic 42, 232-247.

Taylor, M. L., Gwinnett, C., Robinson, L. F., and Woodall, L. C. (2016). Plastic microfibre ingestion by deep-sea organisms. Sci. Rep. 6:33997. doi: 10.1038/ srep33997

Taylor, P. D., James, N. P., Bone, Y., Kuklinski, P., and Kyser, T. K. (2009). Evolving mineralogy of cheilostome bryozoans. Palaios 24, 440-452. doi: 10. 1038/srep33997

Teixidó, N., Garrabou, J., Gutt, J., and Arntz, W. E. (2004). Recovery in Antarctic benthos after iceberg disturbance: trends in benthic composition, abundance, and growth forms. Mar. Ecol. Progr. Ser. 278, 1-16. doi: 10.3354/ meps 278001

Thompson, B. A. W., Davies, N., Goldsworthy, P. M., Riddle, M. J., Snape, I., and Stark, J. S. (2006). In situ lubricant degradation in Antarctic marine sediments 1. Short-term changes. Environ. Toxicol. Chem. 25, 356-366. doi: 10.1897/05015r.1

Thornhill, D. J., Mahon, A. R., Norenburg, J. L., and Halanych, K. M. (2008). Open-ocean barriers to dispersal: a test case with the Antarctic Polar Front and the ribbon worm Parborlasia corrugatus (Nemertea: Lineidae). Mar. Ecol. 17, 5104-5117. doi: 10.1111/j.1365-294X.2008.03970.x

Thrush, S., Dayton, P., Cattaneo-Vietti, R., Chiantore, M., Cummings, V., Andrew, N., et al. (2006). Broad-scale factors influencing the biodiversity of coastal benthic communities of the Ross Sea. Deep Sea Res. Part II Top. Stud. Oceanogr. 53, 959-971. doi: 10.1016/j.dsr2.2006.02.006

Thrush, S. F., and Cummings, V. J. (2011). Massive icebergs, alternation in primary food resources and change in benthic communities at Cape Evans, Antarctica. Mar. Ecol. 32, 289-299. doi: 10.1111/j.1439-0485.2011.00462.x

Trebilco, R., Melbourne-Thomas, J., and Constable, A. J. (2020). The policy relevance of Southern Ocean food web structure: Implications of food web change for fisheries, conservation and carbon sequestration. Mar. Policy 3:103832. doi: 10.1016/j.marpol.2020.103832

UNEP (2006). United Nations Environment Programme, Annual Report of the Secretary General. Available online at: https://wedocs.unep.org/bitstream/ handle/20.500.11822/7476/-UNEP\%202006\%20Annual\%20Report-2007755. pdf (accessed February 1, 2020).

UNGA (2007). Resolution adopted by the General Assembly on 8 December 2006. Available online at: https://documents-dds-ny.un.org/doc/UNDOC/ GEN/N06/500/73/PDF/N0650073.pdf?OpenElement (accessed February 4, 2020).

Van Cauwenberghe, L., Claessens, M., Vandegehuchte, M. B., and Janssen, C. R. (2015). Microplastics are taken up by mussels (Mytilus edulis) and lugworms (Arenicola marina) living in natural habitats. Environ. Pollut. 199, 10-17. doi: 10.1016/j.envpol.2015.01.008 
Van Cauwenberghe, L., Vanreusel, A., Mees, J., and Janssen, C. R. (2013). Microplastic pollution in deep-sea sediments. Environ. Pollut. 182, 495-499. doi: 10.1016/j.envpol.2013.08.013

Vargas, S., Dohrmann, M., Göcke, C., Janussen, D., and Wörheide, G. (2017). Nuclear and mitochondrial phylogeny of Rossella (Hexactinellida: Lyssacinosida, Rossellidae): a species and a species flock in the Southern Ocean. Polar Biol. 40, 2435-2444. doi: 10.1007/s00300-017-2155-7

Vernet, M., Martinson, D., Iannuzzi, R., Stammerjohn, S., Kozlowski, W., Sines, K., et al. (2008). Primary production within the sea-ice zone west of the Antarctic Peninsula: I-Sea ice, summer mixed layer, and irradiance. Deep Sea Res. Part II Top. Stud. Oceanogr. 55, 2068-2085. doi: 10.1016/j.dsr2.2008.05.021

Vernet, M., Sines, K., Chakos, D., Cefarelli, A. O., and Ekern, L. (2011). Impacts on phytoplankton dynamics by free-drifting icebergs in the NW Weddell Sea. Deep Sea Res. II. 58, 1422-1435. doi: 10.1016/j.dsr2.2010. 11.022

Walker, T. R., Reid, K., Arnould, J. P., and Croxall, J. P. (1997). Marine debris surveys at Bird Island, South Georgia 1990-1995. Mar. Pollut. Bull. 34, 61-65. doi: 10.1016/S0025-326X(96)00053-7

Waller, C. L., Griffiths, H. J., Waluda, C. M., Thorpe, S. E., Loaiza, I., Moreno, B., et al. (2017a). Microplastics in the Antarctic marine system: an emerging area of research. Sci. Total Environ. 598, 220-227. doi: 10.1016/j.scitotenv.2017. 03.283

Waller, C. L., Overall, A., Fitzcharles, E. M., and Griffiths, H. (2017b). First report of Laternula elliptica in the Antarctic intertidal zone. Polar Biol. 40, 227-230. doi: 10.1007/s00300-016-1941-y

Walton, D. W. H. and Bonner, W. N. (1985). "History and exploration in Antarctic biology," in Key Environments: Antarctica, eds W. N. Bonner and D. W. H. Walton. (Oxford: Pergamon Press), 1-22. doi: 10.1016/B978-0-08-028881-9. 50006-6

Webb, A. L., Hughes, K. A., Grand, M. M., Lohan, M. C., and Peck, L. S. (2019). Sources of elevated heavy metal concentrations in sediments and benthic marine invertebrates of the western Antarctic Peninsula. Sci. Total Environ. 698:134268. doi: 10.1016/j.scitotenv.2019.134268

Welsford, D. C., Ewing, G. P., Constable, A. J., Hibberd, T., and Kilpatrick, R. (2014). Demersal Fishing Interactions With Marine Benthos in the Australian EEZ of the Southern Ocean: An Assessment of the Vulnerability of Benthic Habitats to Impact by Demersal Gears. The Department of the Environment, Australian Antarctic Division and the Fisheries Research and Development Corporation. Final Report FRDC Project 2006/042 (Kingston, Australia: Australian Antarctic Division and the Fisheries Research and Development Corporation).

Węsławski, J. M., Kendall, M. A., Włodarska-Kowalczuk, M., Iken, K., Kêdra, M., Legezynska, J., et al. (2011). Climate change effects on Arctic fjord and coastal macrobenthic diversity-observations and predictions. Mar. Biodivers. 41, 71-85. doi: 10.1007/s12526-010-0073-9

Wilson, N. G., Schrödl, M., and Halanych, K. M. (2009). Ocean barriers and glaciation: evidence for explosive radiation of mitochondrial lineages in the
Antarctic sea slug Doris kerguelenensis (Mollusca, Nudibranchia). Mar. Ecol. 18, 965-984. doi: 10.1111/j.1365-294X.2008.04071.x

Wlodarska-Kowalczuk, M., Pearson, T. H., and Kendall, M. A. (2005). Benthic response to chronic natural physical disturbance by glacial sedimentation in an Arctic fjord. Mar. Ecol. Prog. Ser. 303, 31-41. doi: 10.3354/meps30 3031

Woodall, L. C., Sanchez-Vidal, A., Canals, M., Paterson, G. L., Coppock, R., Sleight, V., et al. (2014). The deep sea is a major sink for microplastic debris. R. Soc. Open Sci. 1, 140317. doi: 10.1098/rsos.14 0317

Worm, B., Barbier, E. B., Beaumont, N., Duffy, J. E., Folke, C., Halpern, B. S., et al. (2006). Impacts of biodiversity loss on ocean ecosystem services. Science 314, 787-790. doi: 10.1126/science.1132294

Wright, S. L., Rowe, D., Thompson, R. C., and Galloway, T. S. (2013). Microplastic ingestion decreases energy reserves in marine worms. Curr. Biol. 23, R1031R1033. doi: 10.1016/j.cub.2013.10.068

Yves, E. (2019). The Antarctic Treaty: A Unique Governance for the Environment and Science, Encyclopedia of the Environment. Available online at: https://www.encyclopedie-environnement.org/en/society/antarctic-treatyunique-governance-for-environment-and-science/ (accessed April 20, 2020).

Zhang, H., Shin, P. K. S., and Heung, S. G. (2016). Physiological responses and scope for growth in a marine scavenging gastropod, Nassarius festivus (Powys, 1835), are affected by salinity and temperature but not by ocean acidification. ICES J. Mar. Sci. 73, 814-824. doi: 10.1093/icesjms/ fsv208

Ziegler, A. F., Smith, C. R., Edwards, K. F., and Vernet, M. (2017). Glacial dropstones: islands enhancing seafloor species richness of benthic megafauna in West Antarctic Peninsula fjords. Mar. Ecol. Prog. Ser. 583, 1-14. doi: 10.3354/ meps 12363

Zwerschke, N., Morley, S. A., Peck, L. S. and Barnes, D. K. A. (2021). Can Antarctica's zoobenthos 'bounce back' from iceberg scouring impacts driven by climate change. Glob. Chang. Biol. 1-9. doi: 10.1111/gcb.15617

Conflict of Interest: ABC was employed by The PEW Charitable Trusts.

The remaining authors declare that the research was conducted in the absence of any commercial or financial relationships that could be construed as a potential conflict of interest.

Copyright (c) 2021 Brasier, Barnes, Bax, Brandt, Christianson, Constable, Downey, Figuerola, Griffiths, Gutt, Lockhart, Morley, Post, Van de Putte, Saeedi, Stark, Sumner and Waller. This is an open-access article distributed under the terms of the Creative Commons Attribution License (CC BY). The use, distribution or reproduction in other forums is permitted, provided the original author(s) and the copyright owner(s) are credited and that the original publication in this journal is cited, in accordance with accepted academic practice. No use, distribution or reproduction is permitted which does not comply with these terms. 